WSRC-STI-2006-00189, Rev. 0

Key Words:

Environment

Remediation

Retention:

Permanent

\title{
Use of Electron Shuttles to Biologically Enhance Abiotic Dechlorination
}

\author{
(A Research Study of the Monitored Natural Attenuation/Enhanced \\ Attenuation for Chlorinated Solvents Technology Alternative Project)
}

September 19, 2006

Washington Savannah River Company
Savannah River Site
Aiken, SC 29808
$\begin{aligned} & \text { Prepared for the U.S. Department of Energy } \\ & \text { Under Contract Number DEAC09-96- } \\ & \text { SR18500 }\end{aligned}$


WSRC-STI-2006-00189, Rev. 0

\section{DISCLAIMER}

Preparation of this report was coordinated by Washington Savannah River Company (WSRC) for the United States Department of Energy (US DOE) under Contract No. DE-AC09-96SR18500. Extensive effort was made by the authors to assure the accuracy of the contents and interpretation. However, the USDOE nor WSRC, nor any of their employees makes any warranty, expressed or implied, or assumes any legal liability or responsibility for accuracy, completeness, or usefulness, of any information, apparatus, or product or process disclosed herein or represents that its use will not infringe privately owned rights. Reference herein to any specific commercial product, process, or service by trade name, trademark, name, manufacturer or otherwise does not necessarily constitute or imply endorsement, recommendation, or favoring of same by Washington Savannah River Company or by the United States Government or any agency thereof. The views and opinions of the authors expressed herein do not necessarily state or reflect those of the United States Government or any agency thereof.

Printed in the United States of America

Prepared For

U.S. Department of Energy 
WSRC-STI-2006-00189, Rev. 0

September 19, 2006

Page i of vi

Key Words:

Environment

Remediation

Retention:

Permanent

\section{Use of Electron Shuttles to Biologically Enhance Abiotic Dechlorination}

(A Research Study of the Monitored Natural Attenuation/Enhanced Attenuation for Chlorinated Solvents Technology Alternative Project)

Contributing Researchers:

Patrick W. McLoughlin, Microseeps, Inc.

John T. Wilson, US EPA

Robert J. Pirkle, Microseeps, Inc.

Barbara J. Wilson, Consultant

Introduced by:

Karen Vangelas, SRNL

Brian B. Looney, SRNL

September 19, 2006

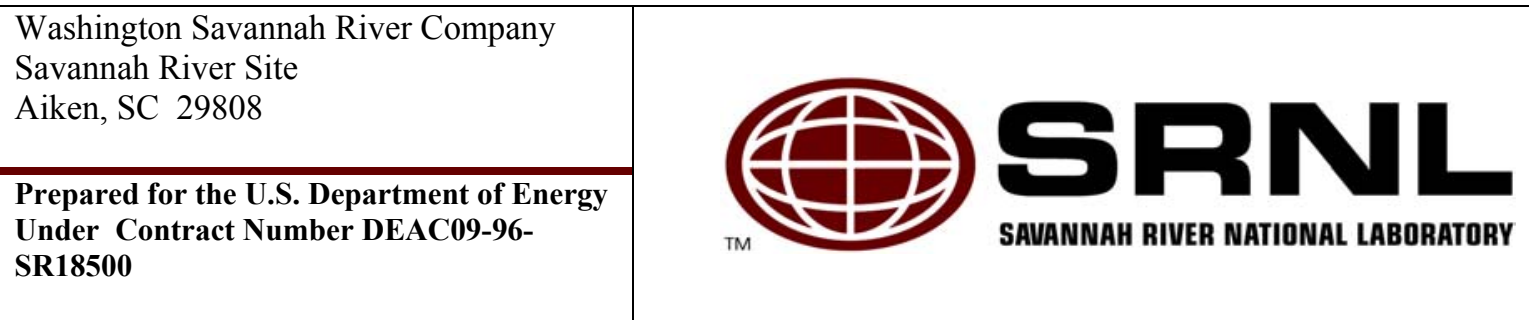




\section{Executive Summary}

Biological anaerobic reductive dechlorination is a robust attenuation mechanism for chlorinated solvents and, under appropriate site conditions, is the dominant attenuation process. When conditions do not favor anaerobic biodegradation, other processes need to be assessed and quantified (EPA, 1998). Abiotic reductive dechlorination is one such mechanism that may contribute to attenuation. A team of researchers conducted studies to develop a method to measure acetylene as an indicator of abiotic reductive dechlorination and to develop a method to enhance this process using electron shuttles. The results of their work indicate additional research is needed to understand and measure this mechanism.

\section{Introduction}

Over the past three decades, much progress has been made in the remediation of soil and groundwater contaminated by chlorinated solvents. Yet these pervasive contaminants continue to present a significant challenge to the U.S. Department of Energy (DOE), other federal agencies, and other public and private organizations. The physical and chemical properties of chlorinated solvents make it difficult to rapidly reach the low concentrations typically set as regulatory limits. These technical challenges often result in high costs and long remediation time frames. In 2003, the DOE through the Office of Environmental Management funded a science-based technical project that uses the U.S. Environmental Protection Agency's technical protocol (EPA, 1998) and directives (EPA, 1999) on Monitored

Natural Attenuation (MNA) as the foundation on which to introduce supporting concepts and new scientific developments that will support remediation of chlorinated solvents based on natural attenuation processes. This project supports the direction in which many site owners want to move to complete the remediation of their site(s), that being to complete the active treatment portion of the remedial effort and transition into MNA.

The overarching objective of the effort was to examine environmental remedies that are based on natural processes - remedies such as Monitored Natural Attenuation (MNA) or Enhanced Attenuation (EA). The research program did identify several specific opportunities for advances based on: 1) mass balance as the central framework for attenuation based remedies, 2) scientific advancements and achievements during the past ten years, 3) regulatory and policy development and real-world experience using MNA, and 4) exploration of various ideas for integrating attenuation remedies into a systematic set of "combined remedies" for contaminated sites. These opportunities are summarized herein and are addressed in more detail in referenced project documents and journal articles, as well as in the technical and regulatory documents being developed within the ITRC.

Three topic areas were identified to facilitate development during this project. Each of these topic areas, 1) mass balance, 2) enhanced attenuation (EA), and 3) innovative characterization and monitoring, was explored in terms of policy, basic and applied research, and the results integrated into a technical approach. Each of these topics is documented in stand alone reports, WSRC-STI-2006-00082, WSRC-STI-2006-00083, 
and WSRC-STI-2006-00084, respectively. In brief, the mass balance efforts are examining methods and tools to allow a site to be evaluated in terms of a system where the inputs, or loading, are compared to the attenuation and destruction mechanisms and outputs from the system to assess if a plume is growing, stable or shrinking. A key in the mass balance is accounting for the key attenuation processes in the system and determining their rates. EA is an emerging concept that is recognized as a transition step between traditional treatments and MNA. EA facilitates and enables natural attenuation processes to occur in a sustainable manner to allow transition from the primary treatment to MNA. EA technologies are designed to either boost the level of the natural attenuation processes or decrease the loading of contaminants to the system for a period of time sufficient to allow the remedial goals to be met over the long-term. For characterization and monitoring, a phased approach based on documenting the site specific mass balance was developed. Tools and techniques to support the approach included direct measures of the biological processes and various tools to support cost-effective long-term monitoring of systems where the natural attenuation processes are the main treatment remedies. The effort revealed opportunities for integrating attenuation mechanisms into a systematic set of "combined remedies" for contaminated sites.

An important portion of this project was a suite of 14 research studies that supported the development of the three topic areas. A research study could support one or more of these three topic areas, with one area identified as the primary target. The following report documents the results of research to develop a method to measure acetylene as an indicator of abiotic reductive dechlorination and to develop a method to enhance this process using electron shuttles. This effort was led by Patrick McLoughlin of Microseeps. This study supports the topic area(s) of enhanced attenuation with mass balance being a secondary development area. There were several specific objectives for this study. They were: 1) Investigate indicator parameters. 2) Evaluate potential to enhance the process. Specifically, a) establish, at bench-top scale, a remediation strategy in which rapid abiotic remediation of chlorinated ethenes is brought about through the addition of a carbon source and humic substance to a contaminated aquifer. b) Develop an analytical methodology for measurement of a parameter that can be used to optimize the treatment process. c) Evaluate methods for sampling and preserving the end-product of the abiotic remediation so the progress of the remediation can be traced.

There is a growing body of literature (Lee and Batchelor [2002a, 2002b, 2003, 2004], Ferrey et al [2004], Danielsen and Hayes [2004], Cervini-Silva et al [2001], and Elsner et al [2004]) documenting abiotic reductive dechlorination. However, techniques to measure the process insitu and methods to sustain the process are needed. This research effort was selected for funding, because advancement of remediation activities supporting abiotic reductive dechlorination will meet the preference as stated in EPA documentation (EPA 1998, 1999) for destructive mechanisms and advancement of techniques for measuring the process in situ will provide quantifiable monitoring methods.

The research team worked diligently and creatively to achieve all of their objectives. Although the proposed hypotheses were reasonable and the work was well performed it was not possible to prove the hypotheses valid. The researchers drew several worthwhile conclusions about the value of existing and alternate methods, even though the proposed 
techniques associated with acetylene and electron shuttle assays did not fully materialize. Acetylene was proven stable at the $\mathrm{pH}$ of a range of preservatives, but it proved to be difficult to measure, presumably because it is not well conserved in the environment. The studies described within did not indicate that electron shuttles resulted in significant increases in abiotic degradation rates. Nor did the bulk electron shuttle capacity assay measurements using chemical reagents prove feasible.

This work should provide some good background information on abiotic processes and monitoring technologies and results. 


\section{References for Introduction}

Cervini-Silva J., R.A. Larson, J. Wu, and J.W. Stucki, 2001. "Transformation of Chlorinated Aliphatic Compounds by Ferruginous Smectite," Environ. Sci. Technol. 35:805-809.

Danielsen, K.M. and K.F. Hayes, 2004. " $\mathrm{pH}$ Dependence of Carbon Tetrachloride Reductive Dechlorination by Magnetite,” Environ. Sci. Technol. 38:4745-4752.

Elsner, M., S.B. Haderlein, T. Kellerhals, S. Luzi, L. Awank, W. Angst, and R.P. Schwarzenbach, 2004. "Mechanisms and Products of Surface-Mediated Reductive Dehalogenation of Carbon Tetrachloride by Fe(II) on Goethite," Environ. Sci. Technol. 38:2058-2066.

EPA, 1998. Technical Protocol for Evaluating Natural Attenuation of Chlorinated Solvents in Groundwater, EPA/600/R-98/128. Washington DC. September 1998.

EPA, 1999. Use of Monitored Natural Attenuation at Superfund, RCRA Corrective Action and Underground Storage Tank Sites, OSWER Directive 9200.4-17P. Washington DC. April 21, 1999.

Ferrey, M.L., R.T. Wilkin, R.G. Ford, and J.T. Wilson, 2004. "Nonbiological Removal of cis-Dichloroethylene and 1,1-Dichloroethylene in Aquifer Sediment Containing Magnetite," Environ. Sci. Technol. 38:1746-1752.

Lee, W. and B. Batchelor, 2002a, "Abiotic reductive dechlorination of chlorinated ethylenes by iron-bearing soil minerals: 1- pyrite and magnetite," Environ. Sci. Technol. 36:5147-5154.

Lee, W. and B. Batchelor, 2002b, "Abiotic reductive dechlorination of chlorinated ethylenes by iron-bearing soil minerals: 2- green rust," Environ. Sci. Technol. 36:53485354.

Lee, W. and B. Batchelor, 2003, "Reductive capacity of natural reductants," Environ. Sci. Technol. 37:535-541.

Lee, W. and B. Batchelor, 2004, "Abiotic reductive dechlorination of chlorinated ethylenes by iron-bearing phyllosilicates," Chemosphere. 56(10):999-1009.

WSRC-STI-2006-00082, 2006. Mass Balance: A Key to Advancing Monitored and Enhanced Attenuation for Chlorinated Solvents. Washington Savannah River Company, Aiken, SC, 29808. June 2006. Available at www.osti.gov.

WSRC-STI-2006-00083, 2006. Enhanced Attenuation: A Reference Guide on Approaches to Increase the Natural Treatment Capacity of a System, Rev 1. Washington Savannah River Company, Aiken, SC, 29808. August 2006. Available at www.osti.gov. 
WSRC-STI-2006-00189, Rev. 0

September 19, 2006

Page vi of vi

WSRC-STI-2006-00084, 2006. Characterization and Monitoring of Natural Attenuation of Chlorinated Solvents in Ground Water: A Systems Approach, Rev 1. Washington

Savannah River Company, Aiken, SC, 29808. August 2006. Available at www.osti.gov. 


\section{Final Project Report: Use of Electron Shuttles to Biologically Enhance Abiotic Dechlorination}

Principal Investigators: Patrick W. McLoughlin, John T. Wilson, Robert J. Pirkle and Barbara J. Wilson 


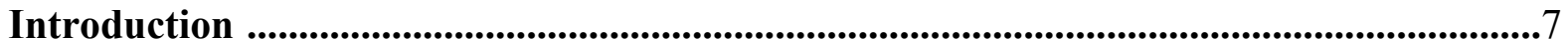

1.0 Use of Dissolved Gases as Indicators of Abiotic Remediation ...............................9

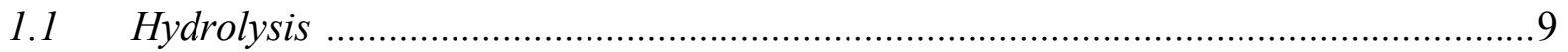

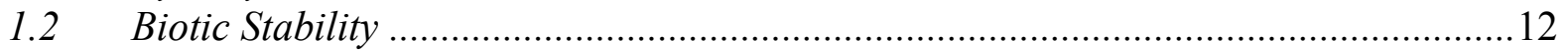

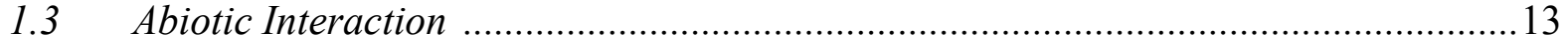

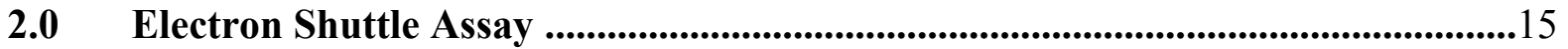

3.0 Abiotic Remediation of PCE in Sterilized, Reduced Sediment ............................23

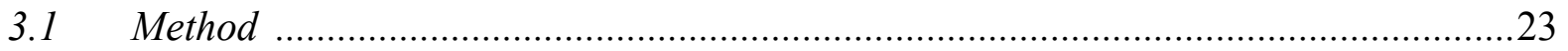

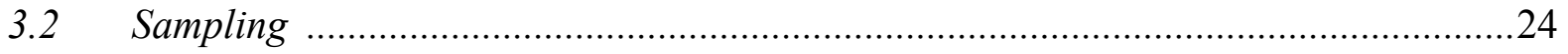

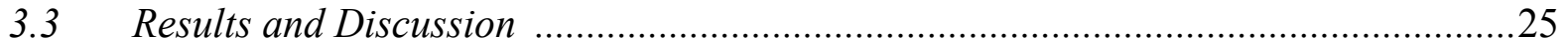

4.0 Abiotic Remediation of PCE in Sediment Amended with an Organic

Substrate and Electron Shuttles .........................................................................................29

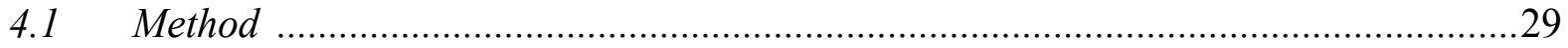

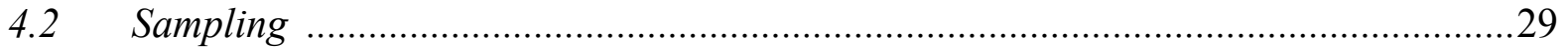

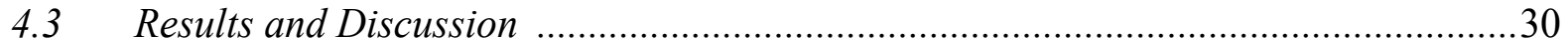

5.0 Abiotic Remediation of TCE in Sterilized, Reduced Sediment ...........................35

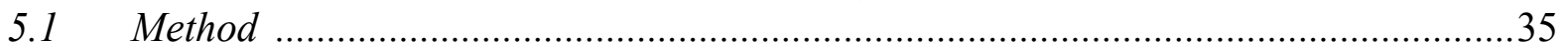

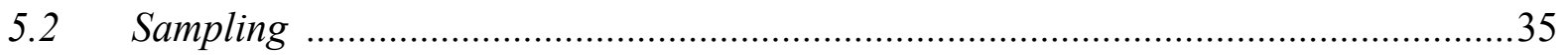

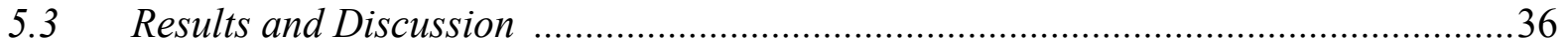

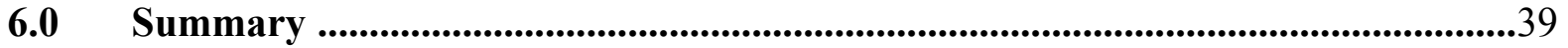

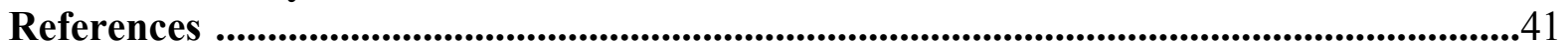

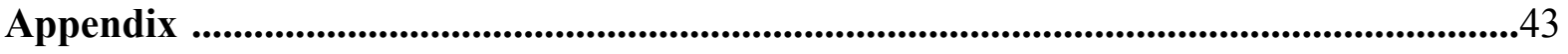

\section{List of Tables}

Table 1. Averaged recoveries at each $\mathrm{pH}$.

Table 2. Gibbs free energies of the reduction and mineralization of acetylene under selected dominant TEAP conditions.

Table 3. Gibbs free energies of the reduction and mineralization of ethene under selected

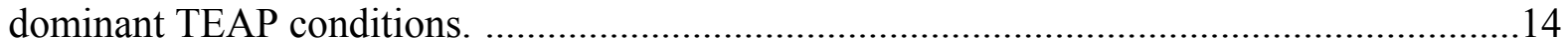

Table 4. Observed changes upon mixture of $10 \mathrm{mM}$ AQDS upon reaction. ..........................16

Table 5. Sulfide spot-test results from sulfide removal experiment. ...................................18

Table 6. Dissolved iron concentrations generated from test of electron shuttle

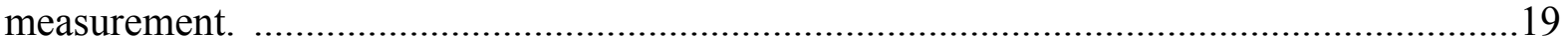

Table 7. Compositions of test of $\mathrm{Na}_{2} \mathrm{~S}$ required to reduce 50 umoles of AQDS. .................21

Table 8. Ferrous Iron concentrations and ORP's for each of the jars used in the effect of

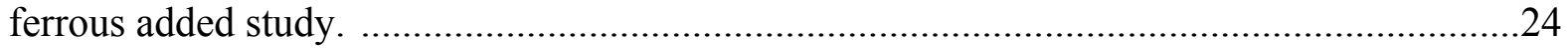

Table 9. Microcosm make-up for effect of ferrous additions study (all additions in $\mathrm{ml}$ ). ......24

Table 10. Microcosm make-up for effect of electron shuttles additions study. ....................29

Table 11. Comparison of statistical loss rates in treatments 3ES - 6ES. .............................34

Table 12. Microcosm make-up for abiotic TCE degradation study. ..................................35

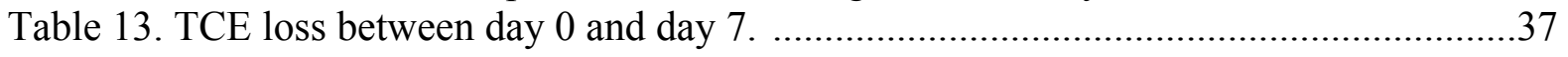




\section{List of Figures}

Page 3 of 82

Figure 1. Stability of acetylene in sterile water at $\mathrm{pH} 2$................................................. 10

Figure 2. Stability of acetylene in sterile water at $\mathrm{pH} 4$.................................................. 10

Figure 3. Stability of acetylene in sterile water at $\mathrm{pH} 7$................................................11

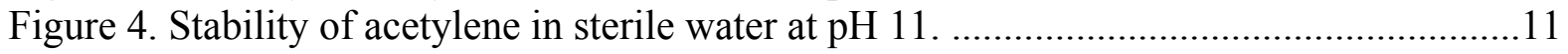

Figure 5. Stability of acetylene in sterile water at $\mathrm{pH} 14$...............................................12

Figure 6. Concentration versus time for the PCE in treatments $1 \mathrm{Fe}, 2 \mathrm{Fe}$ and $3 \mathrm{Fe}$...............26

Figure 7. Concentration versus time for the PCE in treatment $5 \mathrm{Fe}$, the container control

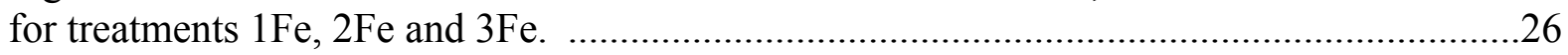

Figure 8. Normalized PCE concentrations vs. time for treatments $1 \mathrm{Fe}, 2 \mathrm{Fe}$ and $4 \mathrm{Fe}$..........27

Figure 9. Concentrations of PCE, TCE and cDCE for treatment 1Fe. ..............................27

Figure 10. Plots of $\ln (\mathrm{TCE})$ vs. time for treatments $1 \mathrm{Fe}, 2 \mathrm{Fe}$ and $5 \mathrm{Fe}$. ..............................28

Figure 11. Plot of PCE conc. for treatments 3ES (1 mM AQDS) and 4ES (5mM AQDS)...30

Figure 12. Plot of PCE conc. for treatments $1 \mathrm{ES}$ ( $0.1 \mathrm{~g}$ lignite) and $2 \mathrm{ES}(0.01 \mathrm{~g}$ lignite)....31

Figure 13. The PCE, TCE and DCE concentration profiles for 3ES. ..................................32

Figure 14. The PCE, TCE and DCE concentration profiles for 4ES. ..................................32

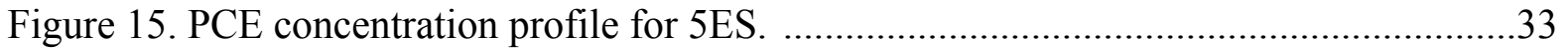

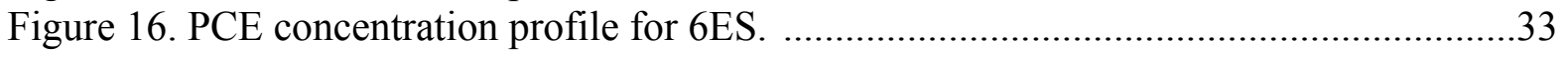

Figure 17. The concentration profile of the TCE in the sterilized sediment. ........................36

Figure 18. The concentration profile for days 0 through 28 of the TCE in the sterilized sediment. 
Conc.

AHDS

AQDS

AU

CSIA

cVOC

DI

EOS

ES

ICAP

NA

ORP

RO

SRS

TES

VOA

bgs

C

$\mathrm{C}_{0}$

$\mathrm{Kg}$

$\mathrm{e}^{-}$

$\mathrm{E}$

$\mathrm{kJ} / \mathrm{mol}$

$\ln$

$\mathrm{mg} / 1$

$\min$

$\mathrm{ml}$

$\mathrm{mM}$

mMolar

$\mathrm{mV}$

$\mathrm{N}$

$\mathrm{nM}$

PPB

PPM

$\mathrm{PPM} \mathrm{CaCO}_{3}$

$\mathrm{ug} / \mathrm{Kg}$

$\mathrm{ug} / \mathrm{l}$

$\mathrm{V}$ concentration

the reduced form of AQDS

anthraquinone-2,6-disulfide

absorbance units

compound specific isotope analysis

chlorinated volatile organic compound

de-ionized water

a suspension of edible soybean oil in water - not an acronym

electron shuttle

inductively coupled argon plasma

not applicable

oxidation-reduction potential

reverse osmosis

Savannah River Site

total electron shuttle

volatile organic analysis

below ground surface

concentration

initial concentration

kilogram

electron

cell half potential

kilo-joule per mol

natural logarithm

milligram per liter

minutes

milliliter

millimolar

millimolar

millivolt

normal

nano-molar

part per billion (in this report $\mathrm{PPB}=\mathrm{ug} / \mathrm{l}$ )

part per million by mass (in this report $\mathrm{PPM}=\mathrm{mg} / \mathrm{l}$ )

PPM as calcium carbonate

microgram per kilogram

microgram per liter

volts

feet 


\section{Chemicals}

\begin{tabular}{|c|c|}
\hline $\mathrm{C}$ & carbon \\
\hline $\mathrm{C}_{2} \mathrm{H}_{2}$ & acetylene \\
\hline $\mathrm{C}_{2} \mathrm{H}_{4}$ & ethene \\
\hline $\mathrm{C}_{2} \mathrm{H}_{6}$ & ethane \\
\hline $\mathrm{CO}_{2}$ & carbon dioxide \\
\hline $1,1 \mathrm{DCE}$ & 1,1 dichloro-ethene \\
\hline cis-DCE & cis-dichloro-ethene \\
\hline $\mathrm{cDCE}$ & cis-dichloro-ethene \\
\hline tDCE & trans dichloro-ethene \\
\hline $\mathrm{Fe}$ & iron \\
\hline $\mathrm{Fe}^{+2}$ & ferrous iron \\
\hline $\mathrm{Fe}^{+3}$ & ferric iron, iron(III) \\
\hline $\mathrm{FeCl}_{2}$ & ferrous chloride \\
\hline $\mathrm{Fe}_{2} \mathrm{O}_{3}$ & iron(III) oxide \\
\hline $\mathrm{H}_{2}$ & molecular hydrogen \\
\hline $\mathrm{H}^{+}$ & hydrogen ion \\
\hline $\mathrm{HCO}_{3}^{-}$ & bicarbonate anion \\
\hline $\mathrm{HCl}$ & hydrochloric acid \\
\hline $\mathrm{H}_{2} \mathrm{O}$ & water \\
\hline $\mathrm{H}_{2} \mathrm{~S}$ & hydrogen sulfide \\
\hline $\operatorname{Mg}(0)$ & magnesium metal, not ionized \\
\hline $\mathrm{NaOH}$ & sodium hydroxide \\
\hline $\mathrm{Na}_{2} \mathrm{~S}$ & sodium sulfide \\
\hline $\mathrm{Na}_{2} \mathrm{~B}_{4} \mathrm{O}_{7}$ & sodium tetra-borate \\
\hline $\mathrm{O}_{2}$ & molecular oxygen \\
\hline PCE & tetra-chloro ethene \\
\hline $\mathrm{S}^{2-}$ & sulfide anion \\
\hline $\mathrm{SO}_{4}{ }^{2-}$ & sulfate anion \\
\hline TCE & tri-chloro ethene \\
\hline TSP & tri-sodium phosphate \\
\hline $\mathrm{VC}$ & vinyl chloride \\
\hline $\mathrm{Zn}(0)$ & zinc metal, not ionized \\
\hline
\end{tabular}


WSRC-STI-2006-00189, Rev. 0

September 19, 2006

Page 6 of 82

(This page intentionally left blank.) 


\section{Introduction}

The initial concept was to stimulate reducing conditions and to use electron shuttle compounds to extend the range and extent of iron reduction, creating aqueous ferrous iron that would in turn adsorb to the iron surfaces and stimulate abiotic remediation. This mechanism had numerous advantages, but relied upon a significant advancement in the science of both electron shuttles and abiotic remediation. While the results are suggestive, the ultimate remedial technique was unable to produce convincing remediation. However, many lessons were learned during the course of this study. To share those lessons most informatively, the results of this work will be presented in five separate sections:

- Use of dissolved gases as indicators of abiotic remediation.

- Electron Shuttle Assay

- Abiotic remediation of PCE in sterilized, reduced sediment

- Abiotic remediation of PCE in sediment amended with an organic substrate and electron shuttles

- Abiotic remediation of TCE in sterilized, reduced sediment 
WSRC-STI-2006-00189, Rev. 0

September 19, 2006

Page 8 of 82

(This page intentionally left blank.) 


\subsection{Use of Dissolved Gases as Indicators of Abiotic Remediation}

If abiotic remediation is going to become a useful remedial tool, we must be able to document it. It is hoped that acetylene, typically the first non-chlorinated product of abiotic remediation, can be used as an indicator that would allow us to document abiotic remediation. However, there are significant questions about the chemistry of acetylene, particularly of acetylene hydrolysis, biotic activity and abiotic interactions. The potential for these interactions must be reviewed if dissolved acetylene is to be used as an indicator of abiotic remediation. This would enable practitioners to know a priori the conditions under which acetylene is not reliably conserved.

\subsection{Hydrolysis}

One possible fate of acetylene would be hydrolysis. Hydrolysis rates are often $\mathrm{pH}$ dependant. To investigate the stability of acetylene in water at multiple $\mathrm{pH}$ 's buffered solutions were prepared, boiled and then placed in serum vials with no headspace and crimp-sealed butyl stoppers. An aliquot of the water was then replaced with an acetylene seeded gas mixture. The vials were shaken to allow for equilibration, and then transferred into VOA vials that were closed with gas-impermeable septa. Two of those vials were then sacrificially sampled on day 0 (the day of sample preparation), 1, 2, 4, 7, 11 and 18. The solutions were a $\mathrm{pH}$ of 2 (that typical of $\mathrm{HCl}$ preservation), 4, 7, 11 (that typical of TSP preservation) and 14 (that typical of $\mathrm{NaOH}$ preservation).

The results are displayed in Figures $1-5$ and summarized in Table 1. As revealed by the data in Table 1, within the error of this experiment, acetylene, ethene and ethane (the later two also in the seed mixture) did not show appreciable loss within 18 days. This implies that on the time scale of typical laboratory turnaround, the hydrolysis of acetylene would not be a problem at any $\mathrm{pH}$. 


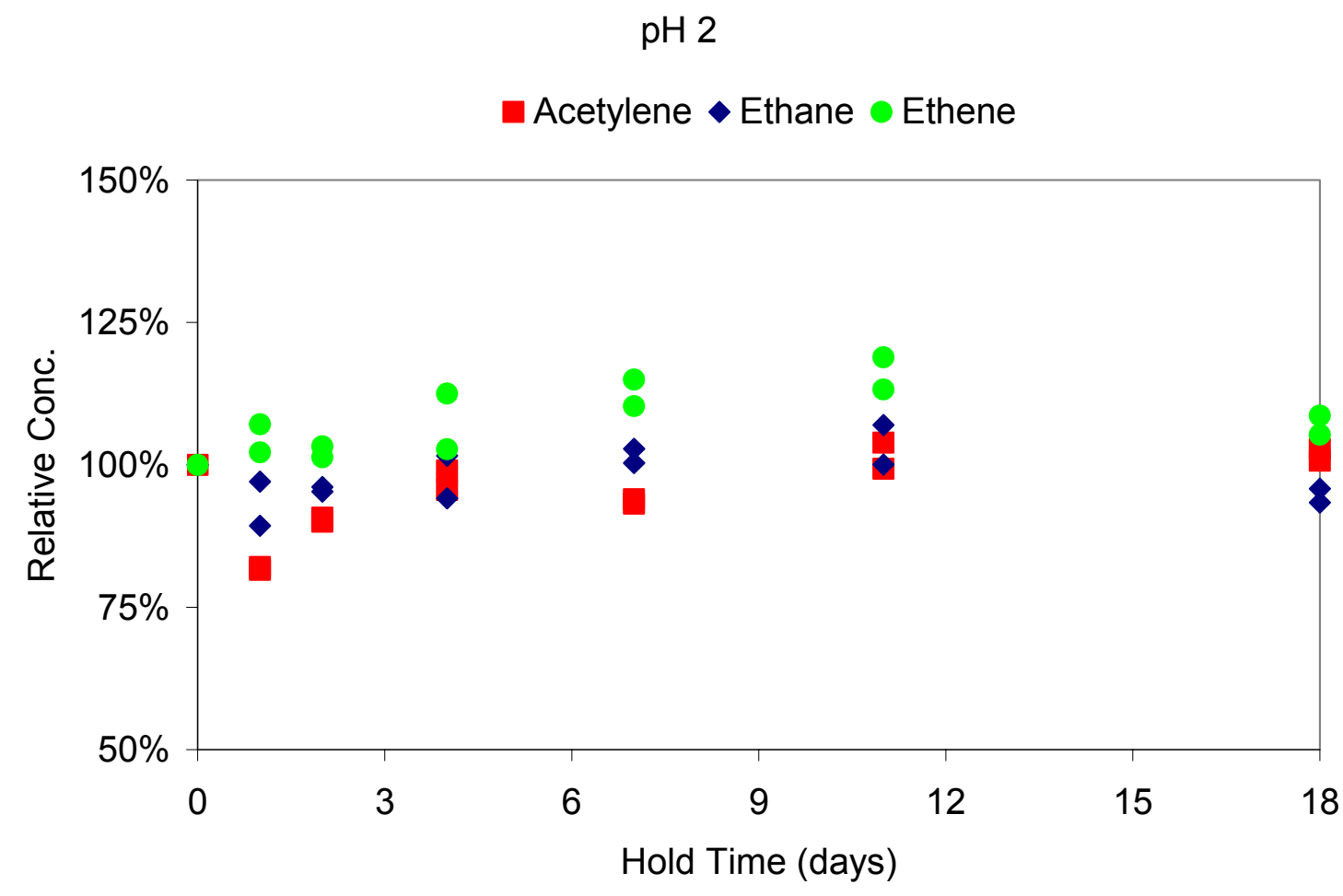

Figure 1. Stability of acetylene in sterile water at pH 2.

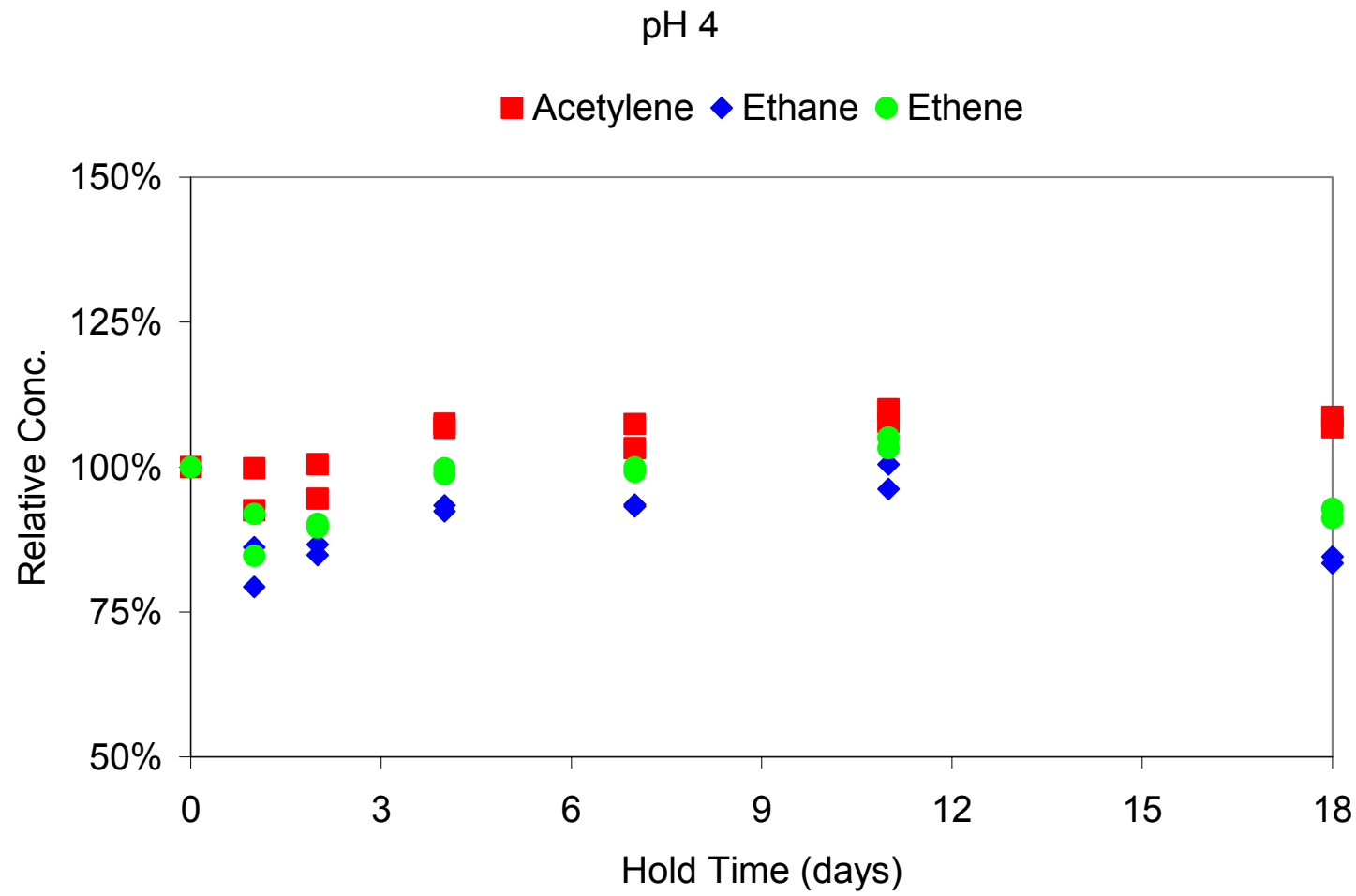

Figure 2. Stability of acetylene in sterile water at pH 4. 


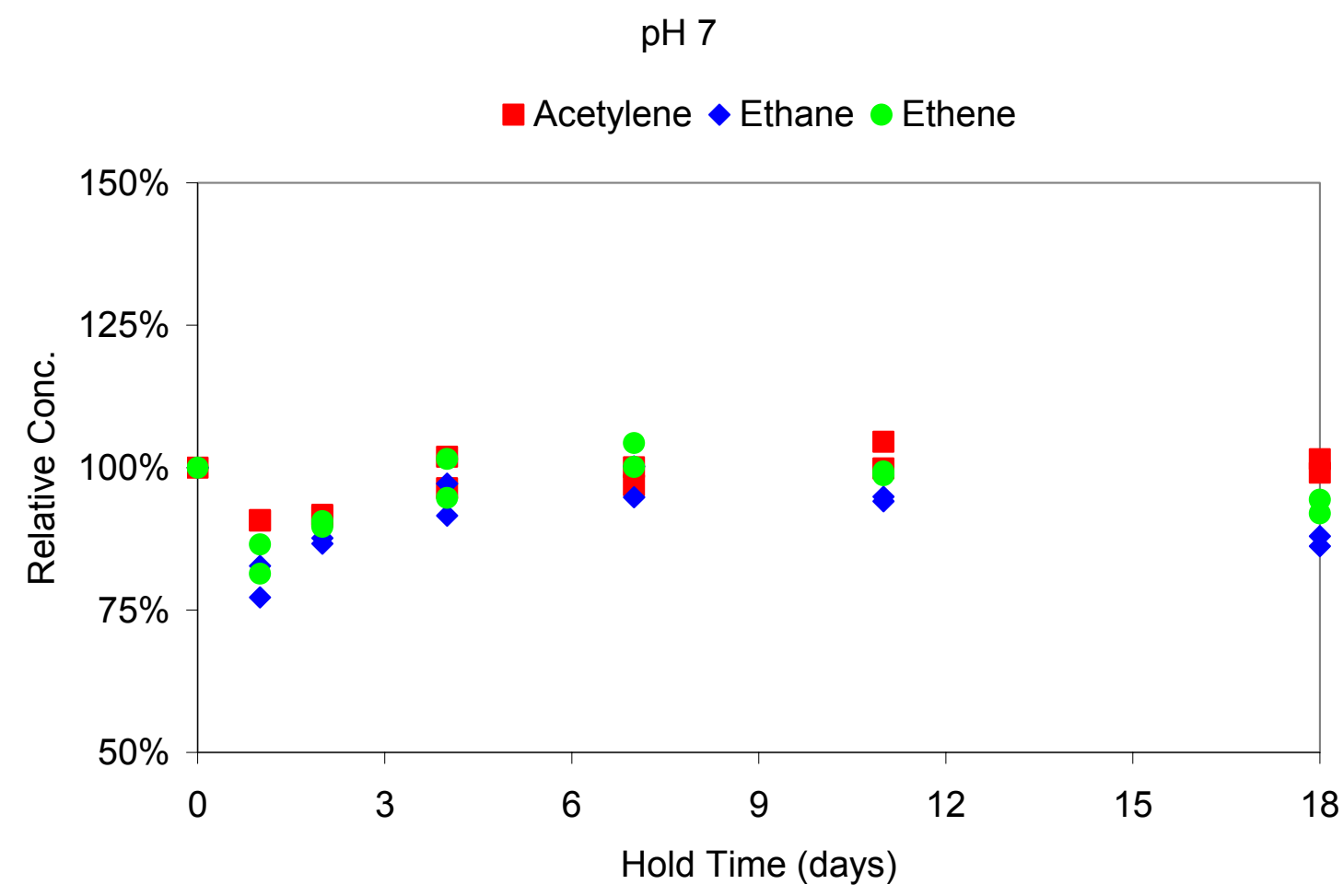

Figure 3. Stability of acetylene in sterile water at pH 7.

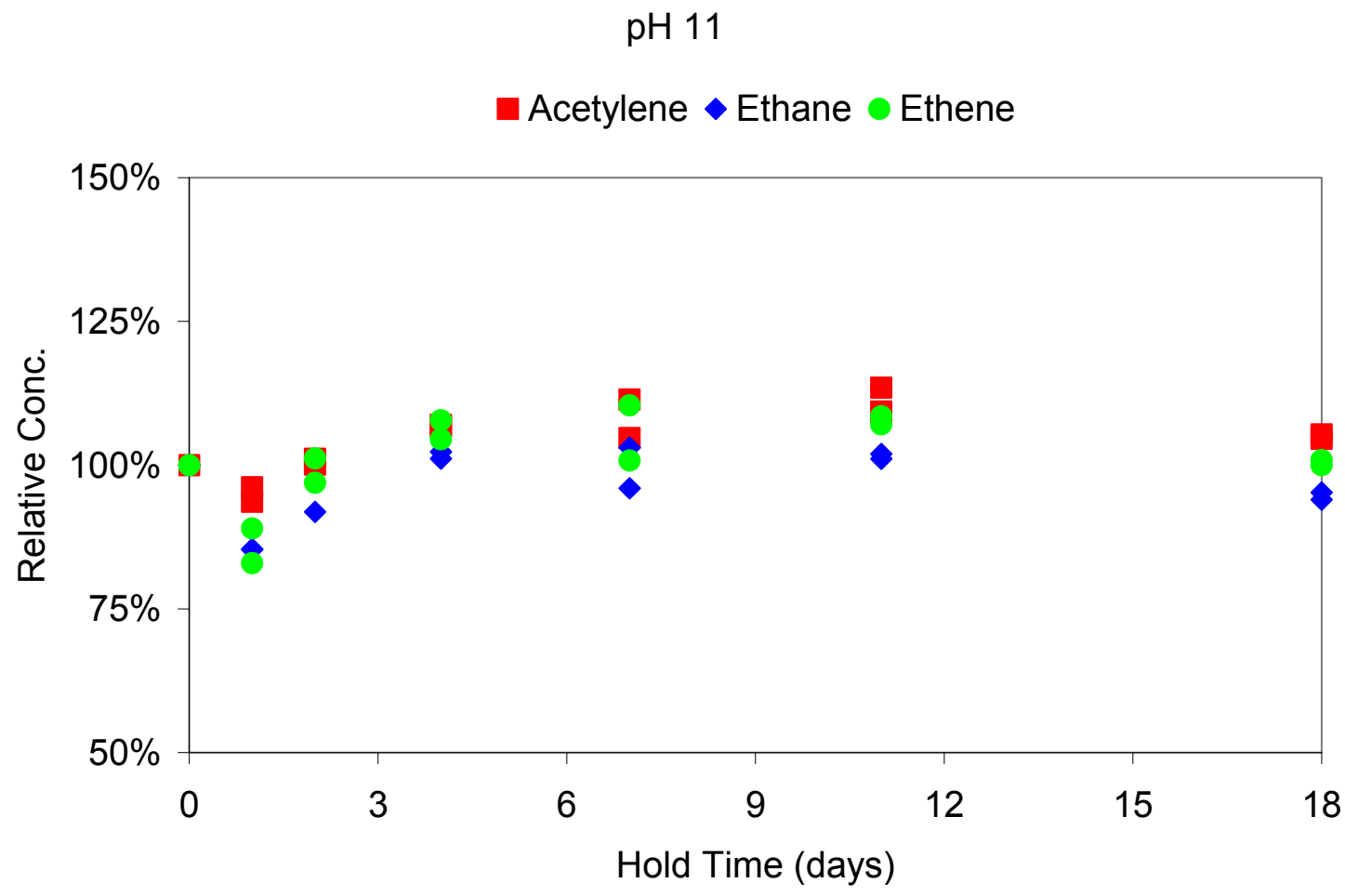

Figure 4. Stability of acetylene in sterile water at pH 11. 
pH 14

Acetylene $\bullet$ Ethane $\bullet$ Ethene

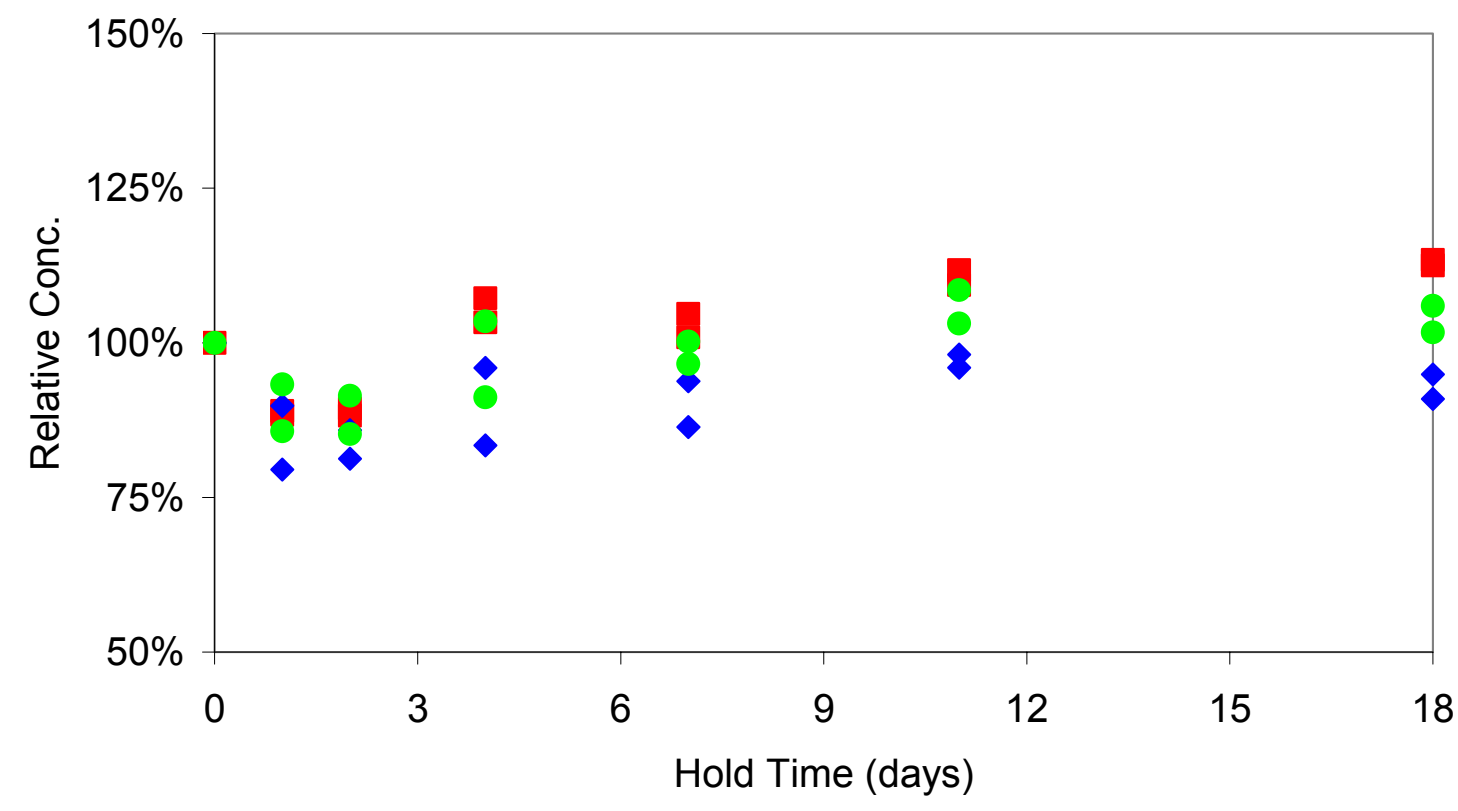

Figure 5. Stability of acetylene in sterile water at $\mathrm{pH} 14$.

Table 1. Averaged recoveries at each $\mathrm{pH}$.

\begin{tabular}{|l|l|l|l|l|l|}
\hline & pH 2 & pH 4 & pH 7 & pH 11 & pH 14 \\
\hline Acetylene & $94 \pm 7$ & $104 \pm 6$ & $97 \pm 5$ & $104 \pm 6$ & $101 \pm 10$ \\
\hline Ethane & $98 \pm 5$ & $90 \pm 6$ & $90 \pm 7$ & $96 \pm 6$ & $90 \pm 6$ \\
\hline Ethene & $108 \pm 6$ & $96 \pm 6$ & $94 \pm 7$ & $101 \pm 8$ & $97 \pm 8$ \\
\hline
\end{tabular}

As this data shows, there is no reason to suspect that chemical reactivity would be a problem in a $\mathrm{pH}$ adjusted sample collected for dissolved acetylene analysis.

\subsection{Biotic Stability}

Many examples of acetylene disappearance and/or utilization were found in the literature. The following are summaries of some of the literature articles that indicates how ubiquitous, under all conditions, acetylene consumption is.

- Watanabe and deGuzman (1980) found rapid disappearance of $\mathrm{C}_{2} \mathrm{H}_{2}$ from soil samples taken from the anaerobic layer of a planted rice paddy. Acetylene disappeared quickly after a 1-day lag.

- Culbertson et al. (1981) found that $\mathrm{C}_{2} \mathrm{H}_{2}$ disappeared and $\mathrm{CO}_{2}$ concurrently increased in anaerobically incubated estuarine sediment slurries. Acetylene loss was inhibited by chloramphenicol, air, and autoclaving. 
- Kanner and Bartha $(1979,1982)$ reported that Nocordia rhodochourus utilized $\mathrm{C}_{2} \mathrm{H}_{2}$ under aerobic conditions ... They reported that $N$. rhodochourus was capable of utilizing $\mathrm{C}_{2} \mathrm{H}_{2}$ as its sole carbon source. They found evidence that $\mathrm{C}_{2} \mathrm{H}_{2}$ is catabolized via acetaldehyde to acetate.

This indicates that there is reason to assume acetylene is a poorly conserved tracer under all conditions in a non-sterile environment.

\subsection{Abiotic Interaction}

Some reports talked about the interaction of acetylene with soils. Braga and Parkin (1997) stated "Yeomans and Beauchamp (1982) observed $\mathrm{C}_{2} \mathrm{H}_{2}$ loss within soil slurries over longer incubation periods under low organic $\mathrm{C}$ conditions but were unable to conclude that $\mathrm{C}_{2} \mathrm{H}_{2}$ was being used as a $\mathrm{C}$ source. Observing no loss of $\mathrm{C}_{2} \mathrm{H}_{2}$ when organic $\mathrm{C}$ was added, they hypothesized that under low organic $\mathrm{C}$ conditions, $\mathrm{C}_{2} \mathrm{H}_{2}$ may absorb to soil particles...". When they perform flow-rate tests with acetylene and a bromide tracer they note that the peak in the breakthrough curve for $\mathrm{C}_{2} \mathrm{H}_{2}$ lagged that of the bromide tracer by an average of $16 \%$. They give no explanation for that lag. But clearly there are a number of interactions in the subsurface retarding the acetylene and they could affect not only the transport but also the fate of acetylene.

While this evidence is convincing, it is admittedly limited. To help overcome that lack, an investigation of the thermodynamics of acetylene stability versus both reduction and mineralization was calculated under conditions conducive to iron reduction, sulfate reduction and methanogenesis. The results are displayed in Table 2. For comparison purposes, the same calculations were repeated for ethene. Those results are displayed in Table 3.

Comparing Tables 2 and 3, it can be seen that all fates of acetylene and ethene that were investigated are much more energetically favorable as fates of acetylene.

Thermodynamics only predicts the energetics of processes, not the rate of those processes, but this investigation shows that if there is a way to affect acetylene reduction or mineralization under anoxic conditions, there is a tremendous energy yield to doing so. This further supports the suggestion that dissolved acetylene can not be relied on as a conservative indicator.

While the stability of dissolved acetylene in the absence of sediment and under sterile conditions is encouraging, from acetylene's ubiquitous consumption by bacteria, acetylene's uncertain loss in soil and the huge thermodynamic drives behind acetylene's destruction under anoxic conditions, it is clear that the absence of acetylene is not indicative of an absence of abiotic remediation. 
Table 2. Gibbs free energies of the reduction and mineralization of acetylene under selected dominant TEAP conditions.

\begin{tabular}{|c|c|c|c|}
\hline $\begin{array}{l}\text { Dominant } \\
\text { TEAP }\end{array}$ & Reduction & Mineralization & Conditions \\
\hline $\begin{array}{l}\text { Iron } \\
\text { Reduction }\end{array}$ & $\begin{array}{l}-102 \mathrm{~kJ} / \mathrm{mol} \\
\mathrm{C}_{2} \mathrm{H}_{2}+\mathrm{H}_{2}== \\
\mathrm{C}_{2} \mathrm{H}_{4}\end{array}$ & $\begin{array}{l}-209 \mathrm{~kJ} / \mathrm{mol} \\
\mathrm{C}_{2} \mathrm{H}_{2}+6 \mathrm{H}_{2} \mathrm{O}==> \\
2 \mathrm{HCO}_{3}{ }^{-}+2 \mathrm{H}^{+}+5 \mathrm{H}_{2}\end{array}$ & $\begin{array}{l}\mathrm{H}_{2}-0.5 \mathrm{nM} \\
\mathrm{pH}-7 \\
\mathrm{C}_{2} \mathrm{H}_{2}-0.2 \mathrm{PPB} \\
\mathrm{C}_{2} \mathrm{H}_{4}-0.1 \mathrm{PPB} \\
\text { Alkalinity }-300 \mathrm{PPM} \mathrm{CaCO}_{3}\end{array}$ \\
\hline $\begin{array}{l}\text { Sulfate } \\
\text { Reduction }\end{array}$ & $\begin{array}{l}-106 \mathrm{~kJ} / \mathrm{mol} \\
\mathrm{C}_{2} \mathrm{H}_{2}+\mathrm{H}_{2}== \\
\mathrm{C}_{2} \mathrm{H}_{4}\end{array}$ & $\begin{array}{l}-223 \mathrm{~kJ} / \mathrm{mol}^{2-} \\
\mathrm{C}_{2} \mathrm{H}_{2}+\mathrm{SO}_{4}{ }^{-}+2 \mathrm{H}_{2} \mathrm{O} \\
==>2 \mathrm{HCO}_{3}{ }^{-}+\mathrm{H}_{2} \mathrm{~S} \\
+\mathrm{H}_{2}\end{array}$ & $\begin{array}{l}\mathrm{H}_{2}-2 \mathrm{nM} \\
\mathrm{C}_{2} \mathrm{H}_{2}-0.2 \mathrm{PPB} \\
\mathrm{C}_{2} \mathrm{H}_{4}-0.1 \mathrm{PPB} \\
\mathrm{SO}_{4}{ }^{2-}-200 \mathrm{PPM} \\
\text { Alkalinity }-300 \mathrm{PPM} \mathrm{CaCO}_{3} \\
\mathrm{H}_{2} \mathrm{~S}-2 \mathrm{PPM}\end{array}$ \\
\hline $\begin{array}{l}\text { Methano- } \\
\text { genesis }\end{array}$ & $\begin{array}{l}-110 \mathrm{~kJ} / \mathrm{mol} \\
\mathrm{C}_{2} \mathrm{H}_{2}+\mathrm{H}_{2}==> \\
\mathrm{C}_{2} \mathrm{H}_{4}\end{array}$ & $\begin{array}{l}-172 \mathrm{~kJ} / \mathrm{mol} \\
\mathrm{C}_{2} \mathrm{H}_{2}+6 \mathrm{H}_{2} \mathrm{O}==> \\
2 \mathrm{HCO}_{3}{ }^{-}+2 \mathrm{H}^{+}+5 \mathrm{H}_{2}\end{array}$ & $\begin{array}{l}\mathrm{H}_{2}-10 \mathrm{nM} \\
\mathrm{pH}-7 \\
\mathrm{C}_{2} \mathrm{H}_{2}-0.2 \mathrm{PPB} \\
\mathrm{C}_{2} \mathrm{H}_{4}-0.1 \mathrm{PPB} \\
\text { Alkalinity }-300 \mathrm{PPM} \mathrm{CaCO}_{3} \mathrm{CaCO}_{3}\end{array}$ \\
\hline
\end{tabular}

Table 3. Gibbs free energies of the reduction and mineralization of ethene under selected dominant TEAP conditions.

\begin{tabular}{|c|c|c|c|}
\hline $\begin{array}{l}\text { Dominant } \\
\text { TEAP }\end{array}$ & Reduction & Mineralization & Conditions \\
\hline $\begin{array}{l}\text { Iron } \\
\text { Reduction }\end{array}$ & $\begin{array}{l}-63.4 \mathrm{~kJ} / \mathrm{mol} \\
\mathrm{C}_{2} \mathrm{H}_{4}+\mathrm{H}_{2}== \\
\mathrm{C}_{2} \mathrm{H}_{6}\end{array}$ & $\begin{array}{l}-105 \mathrm{~kJ} / \mathrm{mol} \\
\mathrm{C}_{2} \mathrm{H}_{4}+6 \mathrm{H}_{2} \mathrm{O}==> \\
2 \mathrm{HCO}_{3}{ }^{-}+2 \mathrm{H}^{+}+6 \mathrm{H}_{2}\end{array}$ & $\begin{array}{l}\mathrm{H}_{2}-0.5 \mathrm{nM} \\
\mathrm{pH}-7 \\
\mathrm{C}_{2} \mathrm{H}_{4}-0.1 \mathrm{PPB} \\
\mathrm{C}_{2} \mathrm{H}_{6}-0.1 \mathrm{PPB} \\
\text { Alkalinity }-300 \mathrm{PPM} \mathrm{CaCO}_{3}\end{array}$ \\
\hline $\begin{array}{l}\text { Sulfate } \\
\text { Reduction }\end{array}$ & $\begin{array}{l}-66.8 \mathrm{~kJ} / \mathrm{mol} \\
\mathrm{C}_{2} \mathrm{H}_{4}+\mathrm{H}_{2}==> \\
\mathrm{C}_{2} \mathrm{H}_{6}\end{array}$ & $\begin{array}{l}-117 \mathrm{~kJ} / \mathrm{mol}^{2-} \\
\mathrm{C}_{2} \mathrm{H}_{4}+\mathrm{SO}_{4}{ }^{2-}+2 \mathrm{H}_{2} \mathrm{O} \\
==>2 \mathrm{HCO}_{3}{ }^{-}+\mathrm{H}_{2} \mathrm{~S} \\
+2 \mathrm{H}_{2}\end{array}$ & $\begin{array}{l}\mathrm{H}_{2}-2 \mathrm{nM} \\
\mathrm{C}_{2} \mathrm{H}_{4}-0.1 \mathrm{PPB} \\
\mathrm{C}_{2} \mathrm{H}_{6}-0.1 \mathrm{PPB} \\
\mathrm{SO}_{4}{ }^{2-}-200 \mathrm{PPM} \\
\mathrm{Alkalinity}^{-3} 300 \mathrm{PPM} \mathrm{CaCO}_{3} \\
\mathrm{H}_{2} \mathrm{~S}-2 \mathrm{PPM}\end{array}$ \\
\hline $\begin{array}{l}\text { Methano- } \\
\text { genesis }\end{array}$ & $\begin{array}{l}-70.8 \mathrm{~kJ} / \mathrm{mol} \\
\mathrm{C}_{2} \mathrm{H}_{4}+\mathrm{H}_{2}==> \\
\mathrm{C}_{2} \mathrm{H}_{6}\end{array}$ & $\begin{array}{l}-60.6 \mathrm{~kJ} / \mathrm{mol} \\
\mathrm{C}_{2} \mathrm{H}_{4}+6 \mathrm{H}_{2} \mathrm{O}==> \\
2 \mathrm{HCO}_{3}{ }^{-}+2 \mathrm{H}^{+}+6 \mathrm{H}_{2}\end{array}$ & $\begin{array}{l}\mathrm{H}_{2}-10 \mathrm{nM} \\
\mathrm{pH}-7 \\
\mathrm{C}_{2} \mathrm{H}_{2}-0.2 \mathrm{PPB} \\
\mathrm{C}_{2} \mathrm{H}_{4}-0.1 \mathrm{PPB} \\
\text { Alkalinity }-300 \mathrm{PPM} \mathrm{CaCO}_{3}\end{array}$ \\
\hline
\end{tabular}




\subsection{Electron Shuttle Assay}

Electron shuttles (ES's) are potentially powerful tools to effect remediation. Indeed, the hypothesis of this work was that electron shuttles can help accelerate abiotic remediation. However, it is difficult to unravel the science of a technique that utilizes electron shuttle concentrations when they can not be meaningfully measured. Without that ability to measure, it still may be possible to unravel the bench scale science, but at field scale it is impossible to engineer such a technique without reliable measurements. The efforts of this portion of the research were focused on developing a broad, inexpensive means of measuring all water-borne organic electron shuttles.

By definition, an electron shuttle is a substance which can be cyclically oxidized and reduced. Cyclic voltammetry can be used to perform repeated cycles of oxidation and reduction, so it seemed a natural choice. Unfortunately, literature reports (Nurmi and Tratnyack, 2002a; Nurmi and Tratnyack, 2002b) have indicated that technical practicalities make the measurement of ground water borne electron shuttles through cyclic voltammetry considerably more laborious than one would estimate based upon conceptual considerations. However, the cycles imposed by cyclic voltammetry can also be imposed by various chemical treatments. Products of those cycles can be collected and quantified. Their measurement is a measurement of the electron shuttle concentration.

Since there are already a number of ways to assess redox conditions (USEPA, 2002), it was decided that the ES assay did not need to address the speciation of the shuttles, but measure the total concentration of both the reduced and oxidized forms of the ES. This greatly simplified sampling, handling, storage and analysis issues.

Simple aeration during sample preparation would convert most electron shuttles to their oxidized form. To cycle the shuttles, they would then need to be reduced. While there are a number of ways to accomplish that reduction, the choices were limited by one requirement: the unreacted portion of the chosen reducing agent must be completely removed from solution, preferably not by precipitation.

One of the reducing agents that met this criterion was sodium sulfide. It was hypothesized that the protonated anion of sodium sulfide could be removed by vacuum, leaving behind only the inactive sodium cation and the anion of the acid that was used to reduce the $\mathrm{pH}$ and protonate the sulfide.

To test sodium sulfide's effectiveness as a reducing agent at various $\mathrm{pH}$ 's, the following test was conducted. In $40 \mathrm{ml}$ clear glass vials $1 \mathrm{ml}$ of $100 \mathrm{mMolar}(\mathrm{mM}) \mathrm{Na}_{2} \mathrm{~S}$ was mixed with $10 \mathrm{ml}$ of $10 \mathrm{mM}$ anthraquinone-2,6-disulfide (AQDS), with the AQDS solution made up in various $\mathrm{pH}$ buffers. The vials were closed with Microseeps' dissolved gas septa (those septa are impermeable to oxygen). The vials were then mixed and the results are presented in Table 4. 
Table 4. Observed changes upon mixture of $10 \mathrm{mM}$ AQDS upon reaction.

\begin{tabular}{|l|l|l|l|}
\hline \multicolumn{2}{|l|}{ Vial } & $\begin{array}{l}\text { Reducing } \\
\text { Agent }\end{array}$ & Color change \\
\hline A & $\mathrm{pH}=1(0.1 \mathrm{Molar} \mathrm{HCl})$ & $10 \mathrm{mM} \mathrm{Na}_{2} \mathrm{~S}$ & None \\
\hline $\mathrm{B}$ & $\mathrm{pH}=4.01$ & $10 \mathrm{mM} \mathrm{Na}_{2} \mathrm{~S}$ & None \\
\hline $\mathrm{C}$ & $\mathrm{pH}=6.86$ & $10 \mathrm{mM} \mathrm{Na} \mathrm{S}_{\mathrm{S}}$ & started yellow, went to orange \\
\hline $\mathrm{D}$ & $\mathrm{pH}=1(0.1 \mathrm{Molar} \mathrm{HCl})$ & $\mathrm{Zn}(0)^{\mathrm{i}}$ & $\begin{array}{l}\text { started yellow, } \\
\text { turned dark green quickly, } \\
\text { went to brownish orange }\end{array}$ \\
\hline $\mathrm{E}$ & $\mathrm{pH}=4.01$ & $\mathrm{Zn}(0)^{\mathrm{i}}$ & $\begin{array}{l}\text { started yellow, turned green, } \\
\text { then dark green, then brownish } \\
\text { orange }\end{array}$ \\
\hline $\mathrm{F}$ & $\mathrm{pH}=6.86$ & $\mathrm{Zn}(0)^{\mathrm{i}}$ & started yellow, went to orange \\
\hline $\mathrm{G}$ & $\mathrm{pH}=1(0.1 \mathrm{Molar} \mathrm{HCl})$ & $\mathrm{Mg}(0)^{\mathrm{ii}}$ & $\begin{array}{l}\text { started yellow, formed pale } \\
\text { orange precipitate in vial and } \\
\text { on ribbon }\end{array}$ \\
\hline $\mathrm{H}$ & $\mathrm{pH}=4.01$ & $\mathrm{Mg}(0)^{\mathrm{ii}}$ & $\begin{array}{l}\text { started yellow, formed dark } \\
\text { orange solution with no } \\
\text { apparent precipitate }\end{array}$ \\
\hline $\mathrm{I}$ & $\mathrm{pH}=6.86$ & $\mathrm{Mg}(0)^{\mathrm{ii}}$ & $\begin{array}{l}\text { started yellow, went to pale } \\
\text { orange with no apparent } \\
\text { precipitate but very slow } \\
\text { reaction }\end{array}$ \\
\hline
\end{tabular}

The first dissociation constant for hydrogen sulfide $\left(\mathrm{H}_{2} \mathrm{~S}\right)$ is $5.7 \times 10^{-8}$. That means that in water at $\mathrm{pHs}$ above 7.2 the majority of the $\mathrm{Na}_{2} \mathrm{~S}$ will be present as $\mathrm{HS}^{-}$, while at pHs below 7.24 the majority of the $\mathrm{H}_{2} \mathrm{~S}$ will be present as $\mathrm{H}_{2} \mathrm{~S}$. Less of the anion is present as the $\mathrm{pH}$ is lowered. The lack of color change observed at low pHs implies that the anion must be present in substantial portions for the reduction to occur. This is further illustrated by the published half-cell potential for the reduction of sulfide:

$$
\begin{array}{ll}
\mathrm{S}+2 \mathrm{H}^{+}+2 \mathrm{e}^{-} \Leftrightarrow \mathrm{H}_{2} \mathrm{~S}(\mathrm{~g}) & \mathrm{E}=+0.14 \mathrm{~V} \\
\mathrm{~S}+2 \mathrm{e}^{-} \Leftrightarrow \mathrm{S}^{2-} & \mathrm{E}=-0.48 \mathrm{~V}
\end{array}
$$

From this it can be seen that the anion is a much stronger reducing agent than the protonated acid, so the reduction favors high $\mathrm{pH}$ 's (i.e. basic conditions).

The vials from the above experiment were prepared with considerable headspace. The vials were prepared under ambient conditions, so that headspace contained oxygen. When vial C was shaken, the color temporarily reverted to yellow. We hypothesized that this was evidence of the oxygen in the vial oxidizing the reduced AQDS. This was a clear indication of the reversibility of the reaction. It later became apparent that the observed effect of in-vial oxidation was also clear evidence of the sensitivity of the system to oxygen. 
Another reducing agent where the un-reacted portion can easily be removed from solution is zinc metal. To test this 3-40 ml clear glass vials were made up with $\sim 5 \mathrm{~g} 20$ mesh zinc in each and $10 \mathrm{ml}$ of AQDS, again in various buffers. The results of this experiment are also listed in Table 4 . The ready reversibility and the dramatic effect of low amounts of oxygen contamination could be seen by shaking vial $\mathrm{F}$ and watching the color temporarily change back to yellow. (That effect could not be seen in the other vials because it was too hard to see through them.)

Forty hours after the preparation of vials D, E and F an orange precipitate could be seen in all vials, with large amounts in vial $\mathrm{D}$. This led to the conclusion that zinc made a poor reducing agent for an electron shuttle test because it formed precipitates with the reduced ES's too easily. Perhaps the concentration of AQDS used in this study (10 mMolar) is higher than will typically be found in field samples, but it was chosen to pursue other alternatives at this juncture.

Because of this precipitate problem 3 more vials were prepared as before but using strips of magnesium ribbon as the reducing agent. The results are presented in Table 4 . The lack of a discernable pattern following the varying $\mathrm{pH}$ was somewhat unsettling, but the results from vial $\mathrm{H}$ were quite promising.

To further explore the use of magnesium ribbon as a reducing agent $1 \mathrm{ml}$ of $10 \mathrm{mM}$ AQDS in 4.01 buffer was mixed into $39 \mathrm{ml}$ of 4.01 buffer and a 3" length of $\mathrm{Mg}$ ribbon was added. At first a small headspace was left $(\sim 1 \mathrm{ml})$ and the vial was capped. Within several minutes the color went from pale yellow to pale green and there was an obvious evolution of gas. It was clear that the $1 \mathrm{ml}$ headspace would not be large enough, so half of the volume was removed from the vial and the reaction was allowed to continue. In the end, it produced a colorless solution and there was an orange coating on the ribbon. Apparently there is a problem between the reduced ES and the Mg ribbon that leads to a coating of the ribbon. Perhaps it was some sort of fouling from this process that led to the observations in vial $\mathrm{G}$ that were not seen in vial $\mathrm{H}$. This has led to the conclusion that $\mathrm{Mg}$ ribbon, while effective, is probably also a poor choice for a quantitative analysis, especially at ES concentrations as high as 10 mMolar.

The reducing agent chosen was sodium sulfide, $\mathrm{Na}_{2} \mathrm{~S}$. It was clear from the previous experiments that the reduction would be affected by sodium sulfide. The issue was removing it from the solution. It was shown above that higher $\mathrm{pH}$ 's were required to drive the reduction, but those high $\mathrm{pH}$ 's also meant that very small amounts of the sulfide would be present as the acid. An experiment would need to be constructed to determine whether the pressure of that acid was large enough to lead to removal of the sulfide by vacuum extraction and whether that removal could be carried out at a reasonable rate.

To do this we needed to measure sulfide concentrations very sensitively and with minimal sample consumption, but only in a semi-quantitative fashion. Spot-tests allow for the mixing of one drop of test sample with 1-2 drops of reagents. Typically, these tests produce a precipitate if positive. The concentration can be judged semi-quantitatively by the amount of precipitate that is formed. Because of the low solubility of zinc sulfide, zinc acetate is often 
used to cause sulfide to precipitate. Since the reduction of the AQDS was to be carried out in a $\mathrm{pH}=9.18$ buffer solution, a test solution of 20 mMolar $\mathrm{Na}_{2} \mathrm{~S}$ in 54 mMolar 9.18 buffer and a blank of 60 mMolar 9.18 buffer were prepared, as was a $200 \mathrm{mMolar}$ solution of zinc acetate. When a drop of the blank was mixed with the zinc acetate, a white precipitate was observed. This was likely the insoluble zinc hydroxide. When a drop of the zinc sulfide test solution was tested with zinc acetate, a white precipitate was also formed. It could not be concluded whether the precipitate was zinc hydroxide or zinc sulfide. If the spot test were to be diagnostic, it was clear that the metal-sulfide precipitate would need to be distinctly different from white.

Lead sulfide gives a black precipitate. Since the volume of lead solution consumed in a test would be approximately $0.05 \mathrm{ml}$, the lead consumption would be minimal and would not produce a significant waste stream concern. The zinc acetate solution was replaced with a lead acetate solution. The spot test was repeated. Using the lead acetate as an indicator, there was a very obvious difference between the blank and the solution that contained sodium sulfide.

With an applicable spot test developed, it was attempted to test the ability to remove the unreacted sodium sulfide from the test solution by applying a vacuum to the test solution. Since it had been found that higher $\mathrm{pH}$ 's were required to affect the reduction of the electron shuttles, the reduction was to be accomplished in a $\mathrm{pH}=9.18$ buffer. The test solution was prepared by mixing $54 \mathrm{ml}$ of $60 \mathrm{mMolar} 9.18$ buffer and $6 \mathrm{ml}$ of a 20 mMolar sodium sulfide solution. That solution was placed under a vacuum and periodically spot-checked for sulfide. The results are presented in Table 5.

Table 5. Sulfide spot-test results from sulfide removal experiment.

\begin{tabular}{|l|l|l|l|}
$\begin{array}{l}\text { Time under } \\
\text { vacuum (min) }\end{array}$ & $\begin{array}{l}\text { drops glacial } \\
\text { acetic acid }\end{array}$ & \multicolumn{1}{l|}{$\begin{array}{l}\text { test } \\
\text { result }\end{array}$} & Comment \\
\hline 0 & 0 & + & spot test is dark \\
\hline 15 & 0 & + & spot test is dark \\
\hline 25 & 0 & + & spot test is dark \\
\hline 60 & 0 & + & spot test is dark \\
\hline 60 & 9 & NA & $\begin{array}{l}\text { pH was } \sim 10 \text { before, } \\
\sim 8 \text { after }\end{array}$ \\
\hline 67 & 9 & + & spot less dark \\
\hline 74 & 9 & + & spot less dark \\
\hline 81 & 9 & + & spot less dark \\
\hline 88 & 9 & + & spot less dark \\
\hline 97 & 9 & $\sim$ & $\begin{array}{l}\text { presence of precipitate questionable, } \\
\text { slight odor still present. }\end{array}$ \\
\hline
\end{tabular}

From Table 5 it is clear that the $\mathrm{pH}$ must be lowered to affect the removal of sulfide in a time practical for a routine analysis. To accommodate this, a sodium tetraborate $\left(\mathrm{Na}_{2} \mathrm{~B}_{4} \mathrm{O}_{7}\right)$ buffer of $\mathrm{pH}=10$ was used rather than a 9.18 buffer. A test solution was constructed to be 10 
mMolar $\mathrm{Na}_{2} \mathrm{~B}_{4} \mathrm{O}_{7}$ and $10 \mathrm{mMolar} \mathrm{Na}_{2} \mathrm{~S}$. This mixture had a $\mathrm{pH}$ of $\sim 10$. A $20 \mathrm{~mL}$ aliquot of that sample was placed into a vacuum chamber and 2 drops of glacial acetic acid were added, bringing the solution $\mathrm{pH}$ to $\sim 7$. Vacuum was applied to the system and the spot test was used to monitor after $0,5,10,15,20$ and 30 minutes of vacuum. As expected, the initial spot test detected a large presence of sulfide. In the 5, 10 and 15 minute tests, the concentration of the precipitate steadily decreased. In the 20 minute test, no precipitate could be observed, though there was still a discernable sulfide odor emanating from the test solution. After 30 minutes of vacuum the spot test was negative and there was only a very faint sulfide odor emanating from the test solution.

Having developed a spot-test for the presence of sulfide and a way to remove unreacted sulfide from the solution, a quantitative conversion of AQDS to AHDS to dissolved iron (i.e. an electron shuttle measurement) was attempted. Solutions of 2, 1, 0.5, 0.1 and 0.05 mMolar AQDS concentration were prepared, each in a 10 mMolar $\mathrm{Na}_{2} \mathrm{~B}_{4} \mathrm{O}_{7}$ buffer solution. We put the solutions into a glove bag. The glove bag was repeatedly flushed with $99.9998 \%$ nitrogen and the nitrogen purge was continually passed through the glove bag throughout the test. All samples showed a color change indicating reduction. However, the manipulation of the sulfide extraction caused a reversal of the color change. Efforts to refine the glove bag procedure so as to eliminate inadvertent oxygen introduction did not eliminate the problem. Despite this observation, excess iron(III) oxide was put into each vial after sulfide removal. It was allowed to incubate for $\sim 36$ hours. The solutions were then filtered through a 0.45 micron filter and the filtrate was collected into a vessel containing 1 drop 1:1 nitric acid. The acidified filtrate was then analyzed on an ICAP as per SW846-6010 and the iron concentrations observed are given in Table 6.

Table 6. Dissolved iron concentrations generated from test of electron shuttle measurement.

\begin{tabular}{|l|l|}
\hline AQDS conc. (mM) & Iron conc. (ppm) \\
\hline 2.00 & +0.0016 \\
\hline 1.00 & -0.0007 \\
\hline 0.500 & +0.0096 \\
\hline 0.100 & -0.0021 \\
\hline 0.0500 & -0.0013 \\
\hline blank & -0.0005 \\
\hline
\end{tabular}

While the $0.500 \mathrm{mMolar}$ AQDS solution produced some iron (the reporting limit for this test is $0.010 \mathrm{ppm}$ ), there is no discernable pattern to the observed iron concentrations, so it could not be said that the test was quantitative. This was consistent with the reversal of the color of the vacuum treated solution. Observing this, it was decided that any further work had to be done in a carefully controlled, oxygen free environment in a glove-box.

To further justify the "proof in concept" behind the postulated procedure and to support the acquisition of the glove-box, it was decided to perform a "proof in concept" test utilizing zinc iron as the reducing agent. Because of the previously observed precipitation problems zinc 
caused, it was not anticipated that this test would be quantitative. However, it was hoped that it would provide a reduced solution of AQDS.

In each of two clear $40 \mathrm{~mL}$ vials, $20 \mathrm{ml}$ of $2 \mathrm{mM}$ AQDS was combined with $20 \mathrm{ml}$ of $20 \mathrm{mM}$ $\mathrm{Na}_{2} \mathrm{~B}_{4} \mathrm{O}_{7}$ and $\sim 5$ gr. zinc filings. The solutions were then capped with gas impermeable caps and mixed. The color change indicative of AQDS reduction was apparent in both vials. In a glove bag, the solutions were then filtered through a 0.45 micron filter. For each, the filtrate was collected into another $40 \mathrm{ml}$ vial. An excess of iron(III) oxide $\left(\mathrm{Fe}_{2} \mathrm{O}_{3}\right)$ was placed in one vial. The vials incubated for approximately 24 hours. Over that time the color change was lost in both vials. However, if the rate of iron(III) oxide reduction by reduced AQDS was faster than the rate of oxidation of reduced AQDS by diffusion of oxygen into the vial, ferrous iron would have been present in the system. Using a 0.45 micron filter the iron(III) oxide was removed from the solution and the filtrate was collected in a vessel that contained 1:1 nitric acid. That filtrate was analyzed for iron via ICAP according to SW846-6010 (USEPA, 1996). The solution which did not have iron(III) oxide in it gave an iron concentration of $-0.0006 \mathrm{ppm}$, The solution that did have a chance to react with iron(III) oxide had an iron concentration of $0.0036 \mathrm{ppm}$.

That result was clearly higher than the solution which had no iron and was clearly higher then all but one of the AQDS solutions produced in the experiments that produced the data in Table 6. This suggests that a solution of AQDS can be reduced and then, after removal of any unreacted reducing agent, be used to reduce iron(III) oxide. Further, this demonstrates that extreme measures must be taken to insure there is no inadvertent oxygenation of the reduced sample during reduction, removal of the excess reducing agent, or incubation of the reduced sample with iron(III) oxide.

The use of sodium sulfide to reduce AQDS is similar to the use of hydroxyl amine hydrochloride to reduce iron(III) in the total iron test described in SM 3500 FE (USEPA, 1996). In that test, the hydroxyl amine is used in at least an eight fold excess. This is considerably stronger then was used in the experiment described to date. If the reducing conditions we generated were only sufficient to reduce $\sim 10 \%$ of the AQDS, it would be much easier to understand how errant oxygen could easily reverse the color changes we produced. Unfortunately, if such an excess of $\mathrm{Na}_{2} \mathrm{~S}$ was required, it would imply that chemical reduction via this approach was impractical.

To test how much excess $\mathrm{Na}_{2} \mathrm{~S}$ was required, two solutions were made up in $1 \mathrm{~cm}$. cuvettes. The solution contained $8.5 \mathrm{ml}$ of $200 \mathrm{PPM} \mathrm{Na} 2 \mathrm{~S}$ and one or two drops of an $10 \mathrm{mM}$ AQDS solution such that the concentration of AQDS (or reduced AQDS) was $0.042 \mathrm{mM}$ in cuvette A and $0.085 \mathrm{mM}$ in cuvette B. Using a "Spec 20" the absorbance was measured at $450 \mathrm{~nm}$ in each cuvette. The results were 0.651 AU in cuvette A and 1.319 AU in B. These absorbances were considerably higher than would have been expected given the extinction coefficient and spectroscopy reported by Cervantes et al (2000). Oxidation of a similarly prepared solution showed a yellow precipitate, presumably sulfur produced by the oxidation of the sulfide that accompanies the reduction of the AQDS. This precipitate was only partially removed by filtration with a 0.45 micron filter. However, it was clear that as the reaction progressed, the absorbance would continue to increase, and we simply needed to 
assess what amount of excess $\mathrm{Na}_{2} \mathrm{~S}$ was required to go to completion, so absorbance spectroscopy was still an appropriate tool for the diagnosis.

Four additional solutions were made up, this time with a constant amount of AQDS but steadily decreasing $\mathrm{Na}_{2} \mathrm{~S}$ doses. The compositions are given in Table 7 . In that table, the additions are specified in micromoles or umoles.

Table 7. Compositions of test of $\mathrm{Na}_{2} \mathrm{~S}$ required to reduce 50 umoles of AQDS.

\begin{tabular}{|l|l|l|l|}
\hline \multicolumn{2}{|c|}{ Solution ID } & $\begin{array}{l}\text { Theoretical Na2S } \\
\text { (umoles) }\end{array}$ & \multicolumn{1}{|l|}{$\begin{array}{l}\text { Added Na2S } \\
\text { (umoles) }\end{array}$} \\
\hline 3 & 50 & 50 & 1000 \\
\hline 4 & 50 & 50 & 600 \\
\hline 5 & 50 & 50 & 400 \\
\hline 6 & 50 & 50 & 200 \\
\hline
\end{tabular}

Solutions were prepared in water with a final volume of $50 \mathrm{ml}$. Following mixing, the solutions were allowed to react overnight. If reduced AQDS were responsible for the color, and the reaction went to completion in all cases, the solutions should all appear the same. In fact, there was a visibly noticeable gradation in color intensity with $3>4>5>6$. If that pattern were produced by variations in the concentration of reduced AQDS even with an extended reaction period, a very large excess of $\mathrm{Na}_{2} \mathrm{~S}$ was required to maximize the absorbance. If that pattern were produced by variations in the content of sulfur in the samples, the inadvertent oxidation of $\mathrm{Na}_{2} \mathrm{~S}$ by very low quantities of stray oxygen was a significant sink to the $\mathrm{Na}_{2} \mathrm{~S}$ and, despite the quantity of $\mathrm{Na}_{2} \mathrm{~S}$ added, an excess could not be assured.

At this point the following drawbacks to this experimental approach had been realized:

1) Sodium sulfide was found to react with some electron shuttles.

In reports by Perlinger, Angst and Schwarzenbach (1996) and Perlinger et al (2002), juglone, a prevalent electron shuttling compound, was found to undergo Michael addition when reacted with $\mathrm{H}_{2} \mathrm{~S}$. $\mathrm{Na}_{2} \mathrm{~S}$, which rapidly forms $\mathrm{H}_{2} \mathrm{~S}$ when dissolved in water, was used.

2) $\mathrm{pH}$ adjustments were necessary to reduce AQDS and again to remove $\mathrm{H}_{2} \mathrm{~S}$.

These $\mathrm{pH}$ adjustments could readily be achieved through the addition of acids and bases. However, each such addition increases the ionic strength of the solution. Since the ES's are sparingly soluble molecules that are mostly hydrophobic, their solubility tends to decrease as the ionic strength is increased. No quantitative experiments were done to prove this, but the formation of precipitates could easily be observed as the solution ionic strength was increased. 
3) Generation of $\mathrm{H}_{2} \mathrm{~S}$ a hazard.

While this is a readily controlled issue and this analysis would be conducted in a glove-box, it must be remembered that an analysis of electron shuttling capacity could readily become commercialized. This means frequent repetition of the analysis and potential execution of the analysis by technicians without the broad knowledge of chemistry that enables the method developers to recognize such hazards and avoid exacerbating them. These potential hazards are magnified by the requirement to use a large excess of $\mathrm{Na}_{2} \mathrm{~S}$ to quantitatively reduce all of the ES's. This potential hazard makes this analysis scheme considerably less appealing.

4) Removal requires gas supply with $<<1 \mathrm{PPM} \mathrm{O}_{2}$. Gases mixtures that are commercially available have a maximum oxygen free capacity of " $<$ $1 \mathrm{PPM} \mathrm{O}_{2}$ ". Reduced AQDS would readily oxidize in such an environment. This means that the atmosphere in which this analysis is conducted either needs to be closed or requires significant purification.

5) Clean gas must flow into chamber at the exact same rate dirty gas exits. To minimize the potential for build-up of $\mathrm{H}_{2} \mathrm{~S}$, it is desirable to continuously flush the atmosphere. Further, to reduce stray oxygen it is required to use dry gas, and the gas flushed through the reaction chambers and the $\mathrm{H}_{2} \mathrm{~S}$ scrubbers is moisture saturated, so replacing that gas is desirable. Since the glove-box can tolerate neither negative nor positive pressure, flushing the glove-box requires an exact balance of inlet and outlet gas flow. This is very difficult to maintain in a low flow environment that can not tolerate any back-streaming of the ambient atmosphere into the glove-box.

6) $\mathrm{H}_{2} \mathrm{~S}$ removal must be complete - presence of $\mathrm{H}_{2} \mathrm{~S}$ during final measurement limits sensitivity.

The ultimate measure is the quantity of iron that is reduced by the reduced solution. If any of the $\mathrm{H}_{2} \mathrm{~S}$ remains in the measured solution, it, not an ES, can reduce iron. It would be assumed that this reduction was due to ES's, and the produced concentration would be biased high. This requirement becomes that much more difficult when considering using large excesses of $\mathrm{H}_{2} \mathrm{~S}$ to quantitatively reduce the ES's.

7) Questionable availability of $\mathrm{Fe}_{2} \mathrm{O}_{3}$ to react with ES.

The hypothesis of this test was that the ES, once reduced, would react with solid phase $\mathrm{Fe}_{2} \mathrm{O}_{3}$. While such a reaction is thermodynamically favored the hypothesized analytical procedure would only work if there were quantitative reaction of all of the reduced ES with the solid phase $\mathrm{Fe}_{2} \mathrm{O}_{3}$. Since a thermodynamically favored reaction is not necessarily a kinetically favored reaction, this hypothesis had to be tested. The work of this project focused on the production of reduced ES, and the reaction of reduced ES with solid phase $\mathrm{Fe}_{2} \mathrm{O}_{3}$ was not tested.

These drawbacks suggested that this analytical procedure was not worth further pursuit. Rather, a reduction of ES with reducing bacteria would be worth investigating for the purpose of electron shuttle measurements. 


\subsection{Abiotic Remediation of PCE in Sterilized, Reduced Sediment}

Abiotic remediation is an effective tool at some sites, and it makes little or no contribution to natural attenuation at other sites. Until it can be initiated at sites where its effect is, as yet, minimal and until such an initiation is proven tenable, it remains a site-specific artifact. In an attempt to initiate abiotic remediation in a documented fashion, a microcosm study was undertaken in which a soil was:

1) collected

2) amended with a carbon substrate and a $\mathrm{pH}$ buffer

3) allowed to incubate until reducing conditions were established

4) sterilized

5) dosed with ferrous iron salts and PCE

The concentration of PCE and several daughter products in the pore water was monitored over time. The following sections report on that study.

\subsection{Method}

The sediment was collected by roto-sonic drilling from P-area of the Savannah River Site (SRS). Cores were taken throughout the 54'-60' bgs. and 74'-80' bgs. intervals. The cores showed sections of gravely-sand that were 1-2' thick between dense clays layers of a similar thickness. Sections of the core which yielded to deformation upon squeezing with one hand were chosen because it seemed that they would yield to water flow most readily. In addition, core sections were favored in which a strong red (presumably from iron hydroxides) could be observed. Core samples of the soils showed there were some benzene, PCE, TCE and cisDCE in the soil, but those concentrations rarely exceeded $10 \mathrm{ug} / \mathrm{Kg}$. There were two exceptions: the TCE at 78' was $354 \mathrm{ug} / \mathrm{Kg}$ and the TCE at 80' was $341 \mathrm{ug} / \mathrm{Kg}$. The sediment was collected in 1 liter canning jars which were topped off with either bore-hole water or DI water then sealed and shipped to the R. S. Kerr Environmental Research Center in Ada, OK.

At the laboratory in Ada the sediments were placed into an "anaerobic" glove-box where they were combined and mixed in a large, stainless steel bowl. A $1 \mathrm{~mL}$ portion of an EOS solution, diluted by 10 in $\mathrm{RO}$ water, was titrated to a $\mathrm{pH}$ of 7 with $1 \mathrm{~N}$ sodium bicarbonate. This titration was used to assess the quantity of bicarbonate that was required to neutralize the EOS, and a larger solution of EOS was prepared accordingly. Thirty (30) $\mathrm{mL}$ of that solution was added to four jars of sediment, approximately $6 \mathrm{Kg}$. The sediment was then mixed and placed into six jars, which were allowed to incubate in the glove-box. After two months, the jar contents were recombined and returned to the six jars. Boiled RO water was added to each jar and allowed to stand overnight. Ferrous iron concentrations and oxidationreduction potentials (ORP's) were measured in each jar and are reported in Table 8. This data suggested that reducing conditions had been established in the sediment and that added ferrous would not simply oxidize but would have a chance to interact with the sediment.

The data presented in Table 8 indicated that reducing conditions had been established in the soil. At that point approximately $33 \mathrm{~g}$ of sediment were placed into each of 30 labeled $20 \mathrm{ml}$ serum vials. Each of the vials was sealed with a Teflon lined butyl rubber stopper type septum, but that septum was not crimped into place. Each microcosm was then weighed and 
Table 8. Ferrous Iron concentrations and ORP's for each of the jars used in the effect of ferrous added study.

\begin{tabular}{|l|l|l|}
\hline Jar \# & Ferrous Iron (mg/l) & ORP (mV) \\
\hline 1 & 1.20 & -579.0 \\
\hline 2 & 1.55 & -574.3 \\
\hline 3 & 1.10 & -584.2 \\
\hline 4 & 2.00 & -580.5 \\
\hline 5 & 1.35 & -575.0 \\
\hline 6 & 1.90 & -574.4 \\
\hline
\end{tabular}

aluminum foil was wrapped around it to hold the stopper in place. The vials were then autoclaved at $250^{\circ} \mathrm{F}$ for 10 hours. After cooling the foil was removed from the vials and they were placed in an anaerobic chamber. Approximately $3 \mathrm{ml}$ of sterile RO water was then added to each microcosm (more was added to those microcosms that had lost more material.

The source of ferrous iron used was ferrous chloride $\left(\mathrm{FeCl}_{2}\right)$. Three solutions of $\mathrm{FeCl}_{2}$ were prepared in $165 \mathrm{ml}$ serum vials. The first contained $1760 \mathrm{mg} \mathrm{FeCl} 2$ and was filled with $\mathrm{RO}$ water. The second and third solutions were prepared identically but contained $535 \mathrm{mg}$ and $176 \mathrm{mg}$ of $\mathrm{FeCl}_{2}$, respectively. The PCE dose solution was prepared by dissolving $33 \mathrm{mg}$ PCE into a $165 \mathrm{ml}$ serum vial. Besides the three levels of ferrous iron additions that were investigated (treatments $1 \mathrm{Fe}-3 \mathrm{Fe}$ ), there was a control with sediment but no ferrous iron addition (treatment $4 \mathrm{Fe}$ ) and a container control that contained no sediment (treatment $5 \mathrm{Fe}$ ). The dose for that container control contained PCE, TCE and cDCE. It was labeled as the $\mathrm{cVOC}$ dose and was prepared by dilutions into $165 \mathrm{ml} \mathrm{RO}$ water. The $\mathrm{FeCl}_{2}, \mathrm{PCE}$ and $\mathrm{cVOC}$ doses and RO water additions were made as outlined in Table 9. RO water was then added so that there was $5 \mathrm{ml}$ of standing water in each sediment-containing microcosm. The microcosm were then sealed with Teflon lined butyl rubber stoppers and crimped.

Table 9. Microcosm make-up for effect of ferrous additions study (all additions in $\mathrm{ml}$ ).

\begin{tabular}{|l|l|l|l|l|l|}
\hline Treatment & sediment & $\mathbf{F e C l}_{\mathbf{2}}$ & PCE & \multicolumn{2}{l|}{$\mathbf{c V O C}$ Water } \\
\hline $1 \mathrm{Fe}$ & yes & $1-1760$ solution $(300 \mathrm{mg} / \mathrm{l})$ & 1 & 0 & 0 \\
\hline $2 \mathrm{Fe}$ & yes & $1-535$ solution $(100 \mathrm{mg} / \mathrm{l})$ & 1 & 0 & 0 \\
\hline $3 \mathrm{Fe}$ & yes & $1-176$ solution $(30 \mathrm{mg} / 1)$ & 1 & 0 & 0 \\
\hline $4 \mathrm{Fe}$ & yes & 0 & 1 & 0 & 1 \\
\hline $5 \mathrm{Fe}$ & no & 0 & 0 & 1 & filled \\
\hline
\end{tabular}

\subsection{Sampling}

Microcosms were sampled on days 2, 7, 14, 21, 28, 41, 54 and 84. All microcosms were sampled in triplicate under anoxic conditions using aseptic techniques. 
Prior to sampling, each microcosm was vortex-mixed. After vortex-mixing, nominally one $\mathrm{ml}$ was collected from the microcosms and diluted to $40 \mathrm{ml}$ for volatiles analysis (PCE, TCE, cDCE, 1,1DCE, tDCE and VC). A second $1 \mathrm{ml}$ aliquot was diluted into $40 \mathrm{ml}$ and that was used for the analysis of dissolved gasses (acetylene, methane, ethane, ethene, propane, propene, n-butane and iso-butane). A third $1 \mathrm{ml}$ aliquot was collected and diluted to $5 \mathrm{ml}$ for the analysis of ferrous iron. The standing water was then replaced with $\mathrm{RO}$ water, the microcosm again was sealed and capped. It was allowed to sit overnight, vortex-mixed, unsealed and sampled for anions (nitrate, nitrite, sulfate and chloride). The remaining solid was then analyzed for weak acid soluble iron. The samples were analyzed at Microseeps Laboratories, using their 2005 Standard Operating Procedures, (i.e. SW846-8260 for the volatiles analysis, PM01/AM20Gax for the dissolved gas analyses, SW846-9056 for the anion analyses, a modified version of SW846 7199 for the ferrous iron analysis and WC43 for the weak acid soluble iron analysis).

\subsection{Results and Discussion}

The detailed results of the analyses carried out on the microcosms are presented in the Appendix, Table A3 - A15. Figure 6 shows the PCE concentrations versus incubation time for treatments $1 \mathrm{Fe}-3 \mathrm{Fe}$. Note that the treatments are labeled according to the pore water concentration of ferrous iron added to the microcosms. The concentration versus time profile of the container control for those microcosms is shown in Figure 7. It does not seem that there is significant degradation of the PCE. If the PCE concentrations recorded in treatments $1 \mathrm{Fe}, 2 \mathrm{Fe}$ and $3 \mathrm{Fe}$ are normalized by the average of the first PCE concentrations measured for those treatments and the results are plotted as PCE $\left(\mathrm{C} / \mathrm{C}_{0}\right)$ vs. $t$ as in Figure 8 , it becomes very clear that from these experiments there is no significant degradation of PCE.

However, there must have been some degradation to produce TCE. In Figure 9 the TCE concentration is plotted for the treatment with $300 \mathrm{mg} / 1$ of Fe ${ }^{+2}$ added to each microcosm. The appearance of TCE and its rapid degradation are consistent. Again, from Figure 9 we see that some cDCE was formed, but that was very minor. Similar patterns were observed in treatment $2 \mathrm{Fe}$ which had $100 \mathrm{mg} / 1 \mathrm{Fe}+{ }^{2}$ added. Indeed, $\ln (\mathrm{TCE}) \mathrm{vs}$. $\mathrm{t}$ from those two treatments is plotted in Figure 10, as well as $\ln (\mathrm{TCE})$ for the container control. It can be seen that in $1 \mathrm{Fe}$ and $2 \mathrm{Fe}$ the degradation is significant.

While it was not clear why TCE was so much more reactive than PCE, the results were quite compelling. It was decided to halt further sampling of the microcosms and to re-spike them with ferrous iron and TCE so that the stimulated abiotic remediation of TCE could be investigated further. 


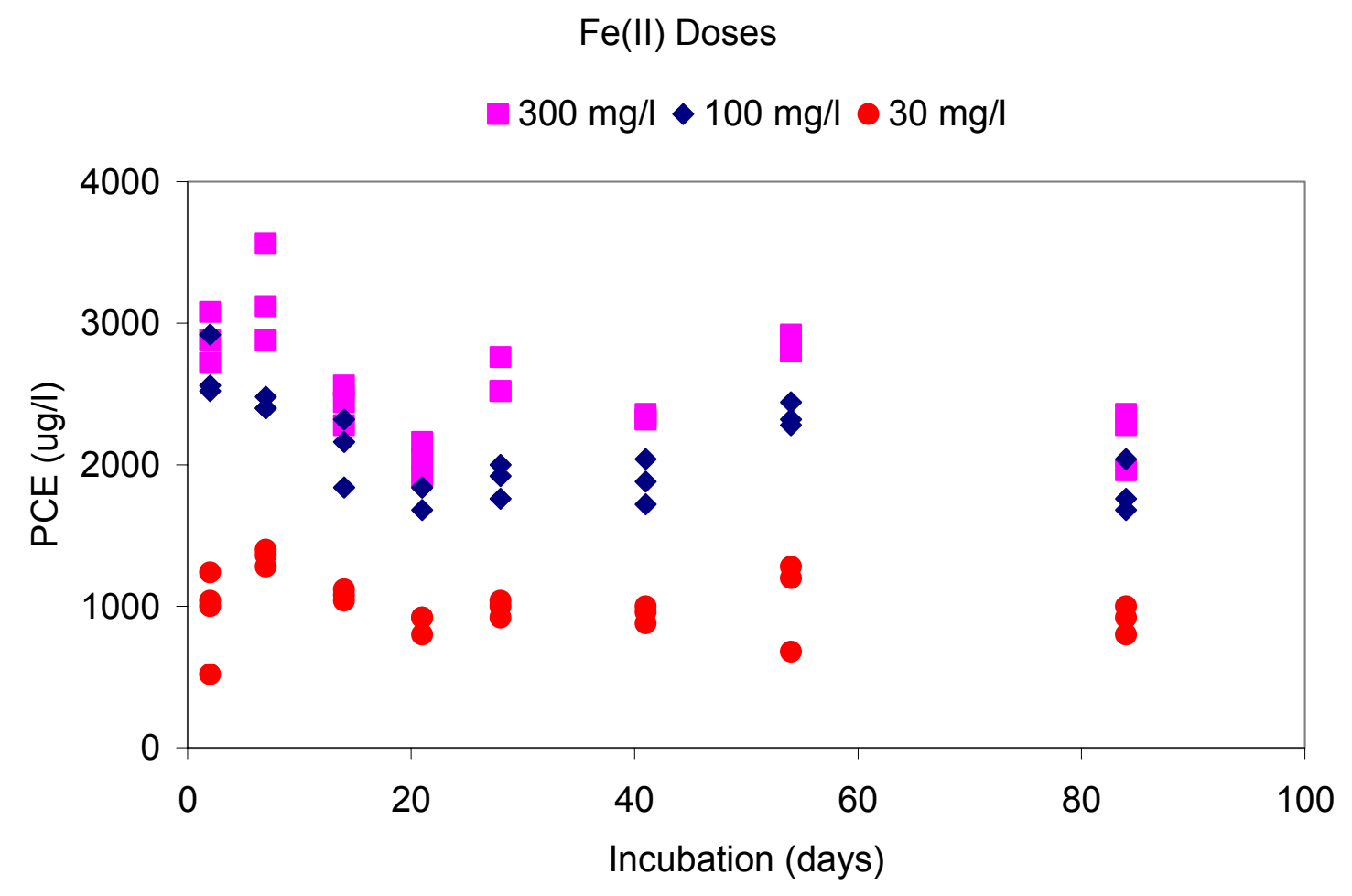

Figure 6. Concentration versus time for the PCE in treatments $1 \mathrm{Fe}, 2 \mathrm{Fe}$ and $3 \mathrm{Fe}$.

- PCE TCE $\triangle \mathrm{tDCE} \bullet \mathrm{cDCE}$

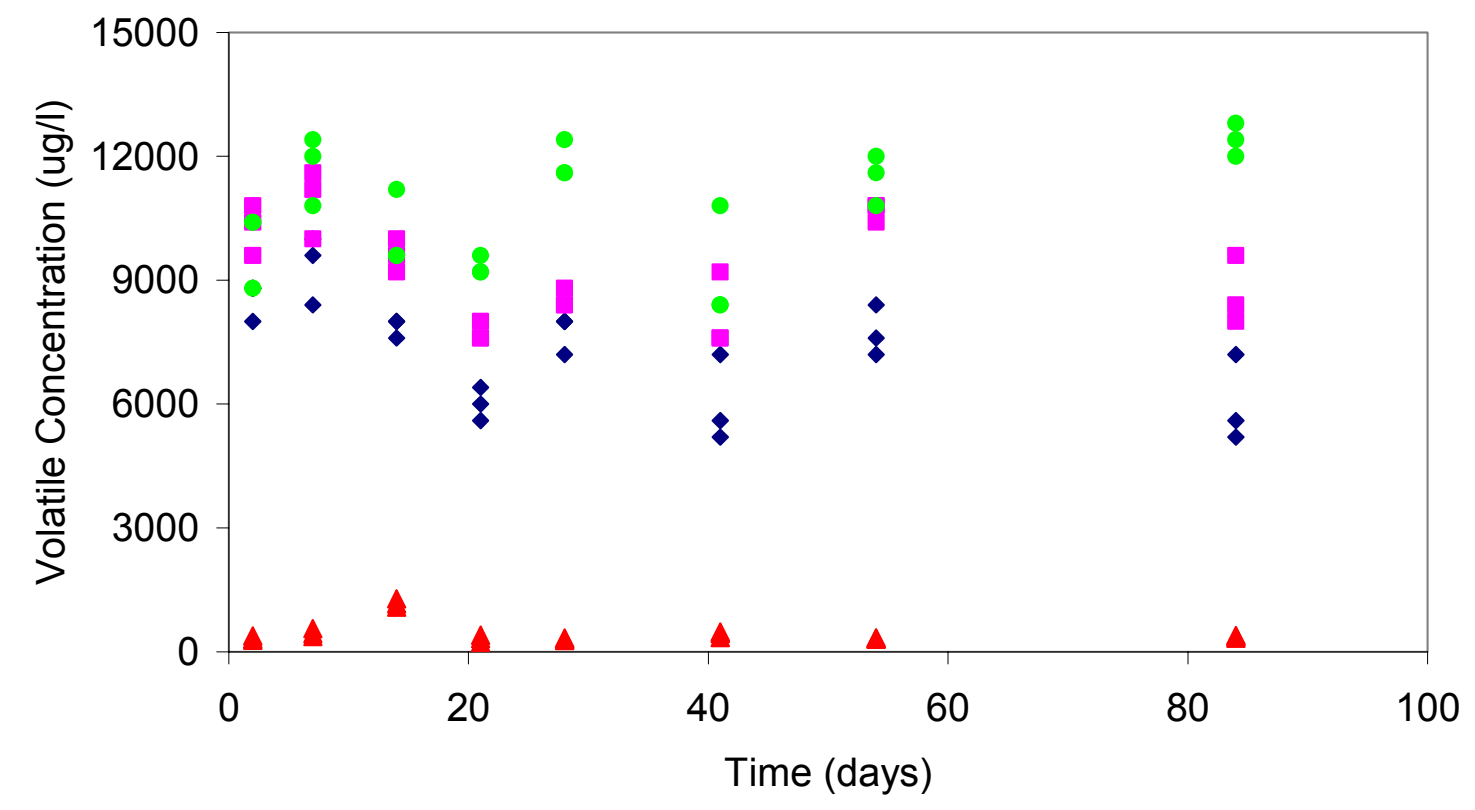

Figure 7. Concentration versus time for the PCE in treatment $5 \mathrm{Fe}$, the container control for treatments $1 \mathrm{Fe}, 2 \mathrm{Fe}$ and $3 \mathrm{Fe}$. 


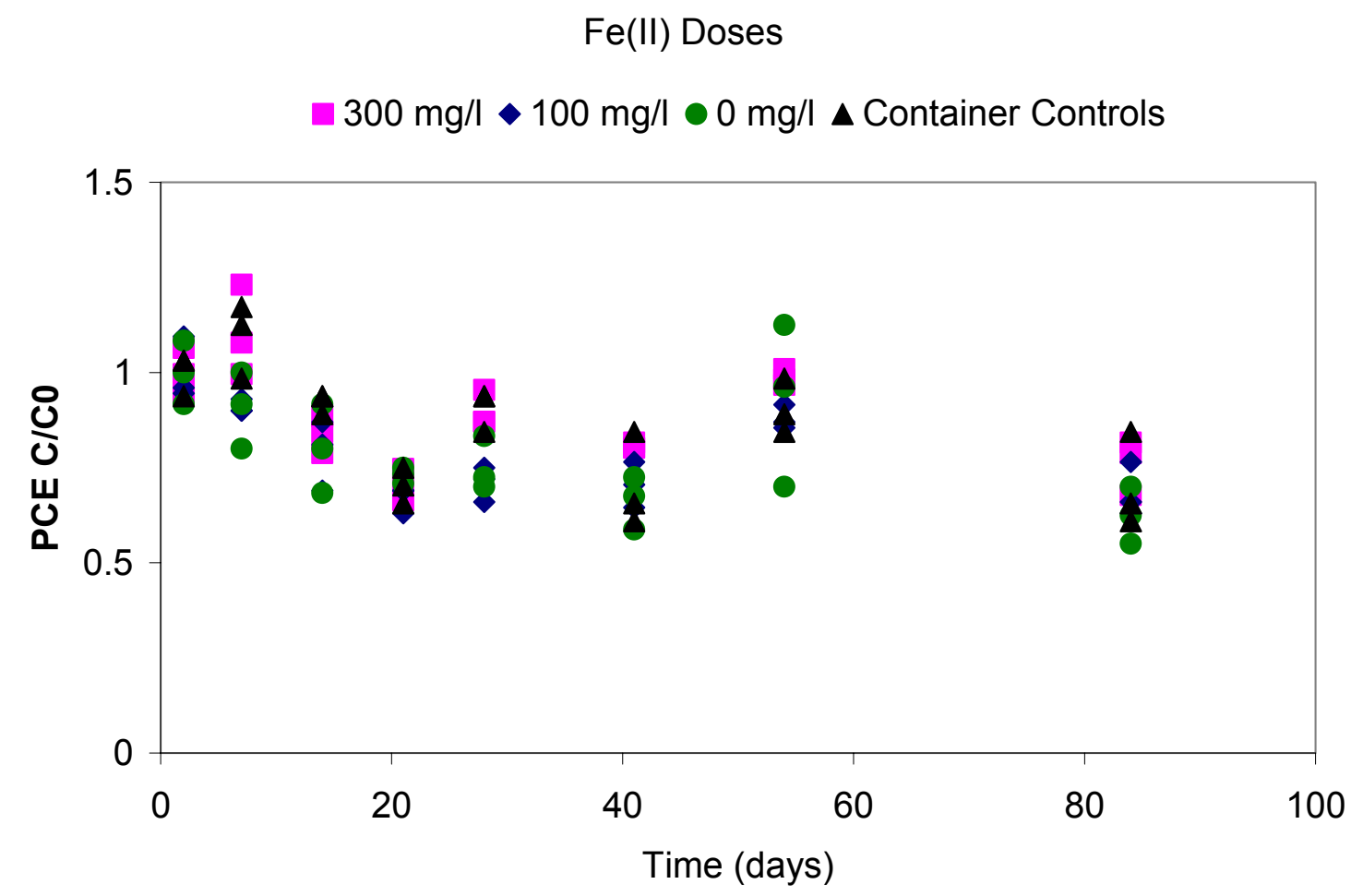

Figure 8. Normalized PCE concentrations vs. time for treatments $1 \mathrm{Fe}, 2 \mathrm{Fe}$ and $4 \mathrm{Fe}$.

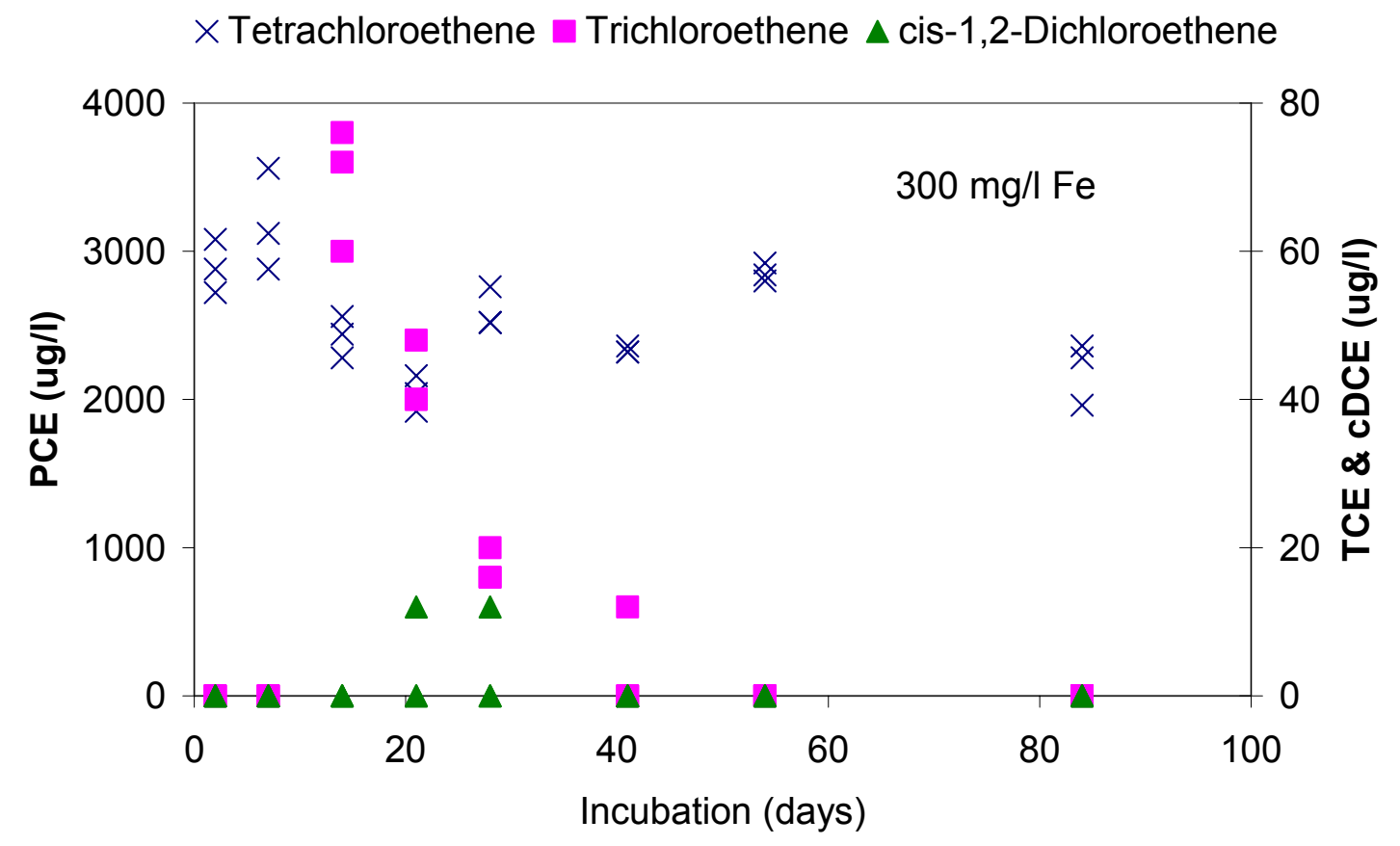

Figure 9. Concentrations of PCE, TCE and cDCE for treatment $1 \mathrm{Fe}$. 
WSRC-STI-2006-00189, Rev. 0

September 19, 2006

Page 28 of 82

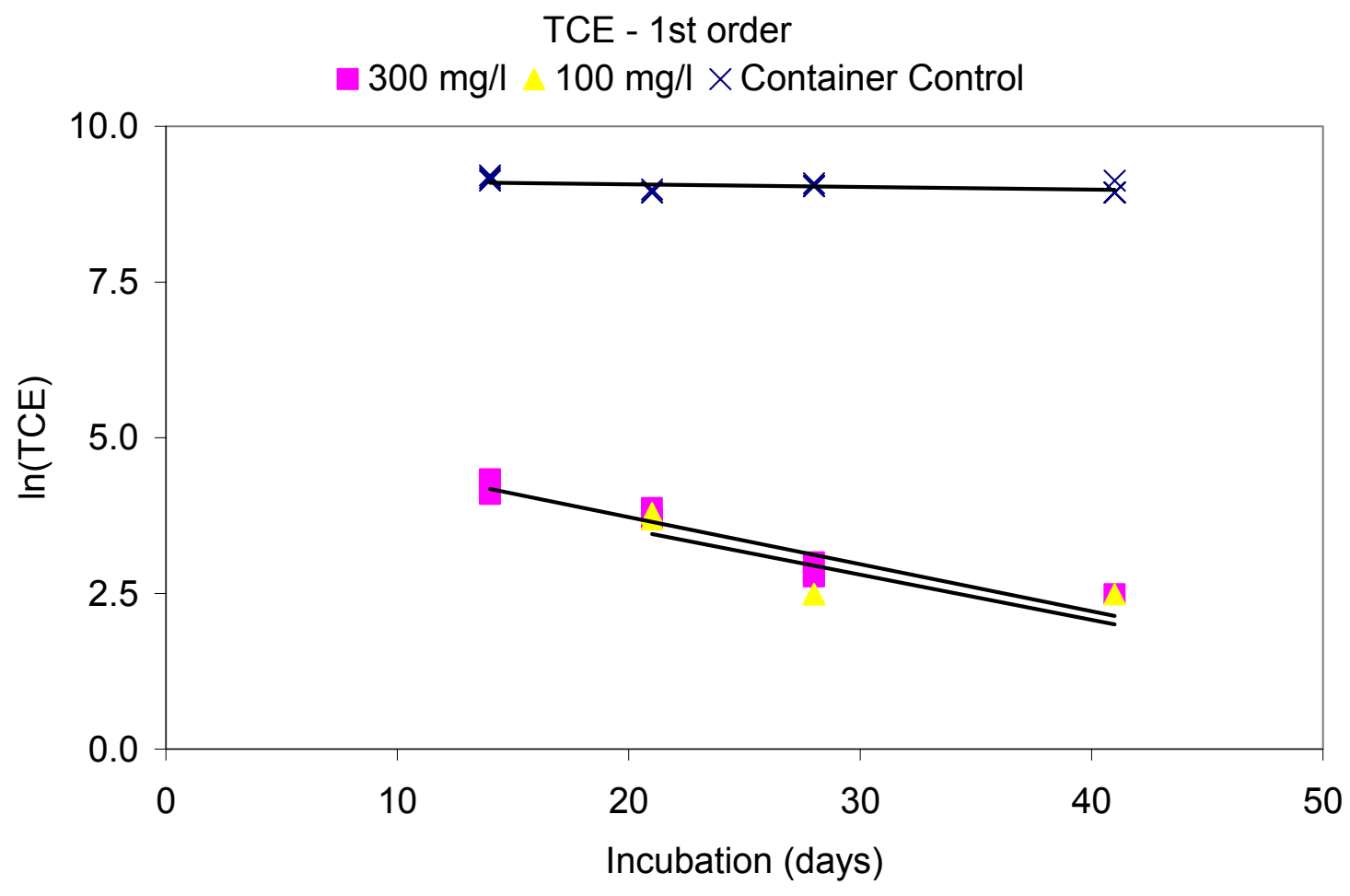

Figure 10. Plots of $\ln (\mathrm{TCE})$ vs. time for treatments $1 \mathrm{Fe}, 2 \mathrm{Fe}$ and $5 \mathrm{Fe}$. 


\subsection{Abiotic Remediation of PCE in Sediment Amended with an Organic Substrate and Electron Shuttles}

Since it is not possible to establish abiotic conditions by sterilizing a site, any real world strategy to effect abiotic remediation must also work with and account for biological processes occurring alongside abiotic processes. In recognition of this it was decided not just to let the two work side by side, but rather to make it possible to let biological processes fuel abiotic dechlorination. Such a process moves the restriction upon the participating microbes from one that requires the microbes be capable of remediating chlorinated ethenes to one that simply requires they foster a reducing environment through the anaerobic consumption of a carbon substrate.

\subsection{Method}

The soil was collected with the soil used in the previous experiment and the microcosms were prepared in Ada, OK. EOS was diluted by ten in $\mathrm{RO}$ water and titrated to $\mathrm{pH} 7$ with bicarbonate. Following neutralization $0.2 \mathrm{ml}$ was added to each sediment containing microcosm such that the EOS was present at approximately $1000 \mathrm{mg} / \mathrm{L}$. The PCE dose solution was prepared by dissolving $33 \mathrm{mg}$ PCE into $165 \mathrm{ml}$ of RO water. Two electron shuttles were investigated: AQDS (9,10-anthraquinone-2,6-disulfonic acid disodium salt) and lignite. To dose AQDS at 1 and $5 \mathrm{mM}$ in the microcosms, 10 and $50 \mathrm{mM}$ solutions were made by dissolving $680 \mathrm{mg}$ and $3400 \mathrm{mg}$ AQDS in $165 \mathrm{ml}$ vials of RO water in $165 \mathrm{ml}$ serum vials that contained magnetic stir bars. The vials were then sealed with Teflon-lined butyl rubber stoppers, crimped and mixed. Approximately $33 \mathrm{~g}$ of sediment was placed into each of the $20 \mathrm{ml}$ serum vials. Two levels of lignite addition (treatments 1ES and 2ES) were investigated as well as two levels of AQDS addition (treatments 3ES and 4ES) and a control with no electron shuttle addition (treatment 5ES). A container control with only PCE and RO water was also performed (treatment 6ES). The preparation of each treatment is detailed in Table 10 .

Table 10. Microcosm make-up for effect of electron shuttles additions study.

\begin{tabular}{|l|l|l|l|l|}
\hline Treatment & sediment & AQDS (ml) & lignite & RO Water \\
\hline $1 \mathrm{ES}$ & yes & 0 & $0.1 \mathrm{~g} / 10 \mathrm{ml}$ pore water & $1 \mathrm{ml}$ \\
\hline $2 \mathrm{ES}$ & yes & 0 & $0.01 \mathrm{~g} / 10 \mathrm{ml}$ Pore water & $1 \mathrm{ml}$ \\
\hline $3 \mathrm{ES}$ & yes & $1-10 \mathrm{mM}$ solution & 0 & $0 \mathrm{ml}$ \\
\hline $4 \mathrm{ES}$ & yes & $1-50 \mathrm{mM}$ solution & 0 & $0 \mathrm{ml}$ \\
\hline $5 \mathrm{ES}$ & yes & 0 & 0 & $1 \mathrm{ml}$ \\
\hline $6 \mathrm{ES}$ & no & 0 & 0 & filled \\
\hline
\end{tabular}

\subsection{Sampling}

Microcosms were sampled on days 0, 32, 60, 95, 125, 158 and 200. All microcosms were sampled in triplicate under anoxic conditions using aseptic techniques. 
Prior to sampling, each microcosm was vortex-mixed. After vortex-mixing, nominally one $\mathrm{ml}$ was collected from the microcosms and diluted to $40 \mathrm{ml}$ for volatiles analysis (PCE, TCE, cDCE, 1,1DCE, tDCE and VC). A second $1 \mathrm{ml}$ aliquot was diluted into $40 \mathrm{ml}$ and that was used for the analysis of dissolved gasses (acetylene, methane, ethane, ethene, propane, propene, n-butane and iso-butane). A third $1 \mathrm{ml}$ aliquot was collected and diluted to $5 \mathrm{ml}$ for the analysis of ferrous iron. The standing water was then replaced with $\mathrm{RO}$ water, the microcosm again was sealed and capped. It was allowed to sit overnight, vortex-mixed, unsealed and sampled for anions (nitrate, nitrite, sulfate and chloride). The remaining solid was then analyzed for weak acid soluble iron. The samples were analyzed at Microseeps Laboratories, using their 2005 Standard Operating Procedures, (i.e. SW846-8260 for the volatiles analysis, PM01/AM20Gax for the dissolved gas analyses, SW846-9056 for the anion analyses, a modified version of SW846 7199 for the ferrous iron analysis and WC43 for the weak acid soluble iron analysis).

\subsection{Results and Discussion}

The detailed results of the analyses carried out on the microcosms are presented in the Appendix, Table A16-A35. In Figure 11 the concentration of PCE is plotted for the experiments where AQDS was added (treatments 3ES and 4ES). Similarly, in Figure 12 the concentration of PCE is plotted for the experiments where lignite was added (treatments 1ES and 2ES) with the TCE. There appears to be some order to the PCE profiles in the AQDS experiments and the rate of decay seems to scale with the AQDS amendment, but it is difficult to find any order in the lignite experiments.

\section{- $1 \mathrm{mM}$ AQDS $=5 \mathrm{mM}$ AQDS}

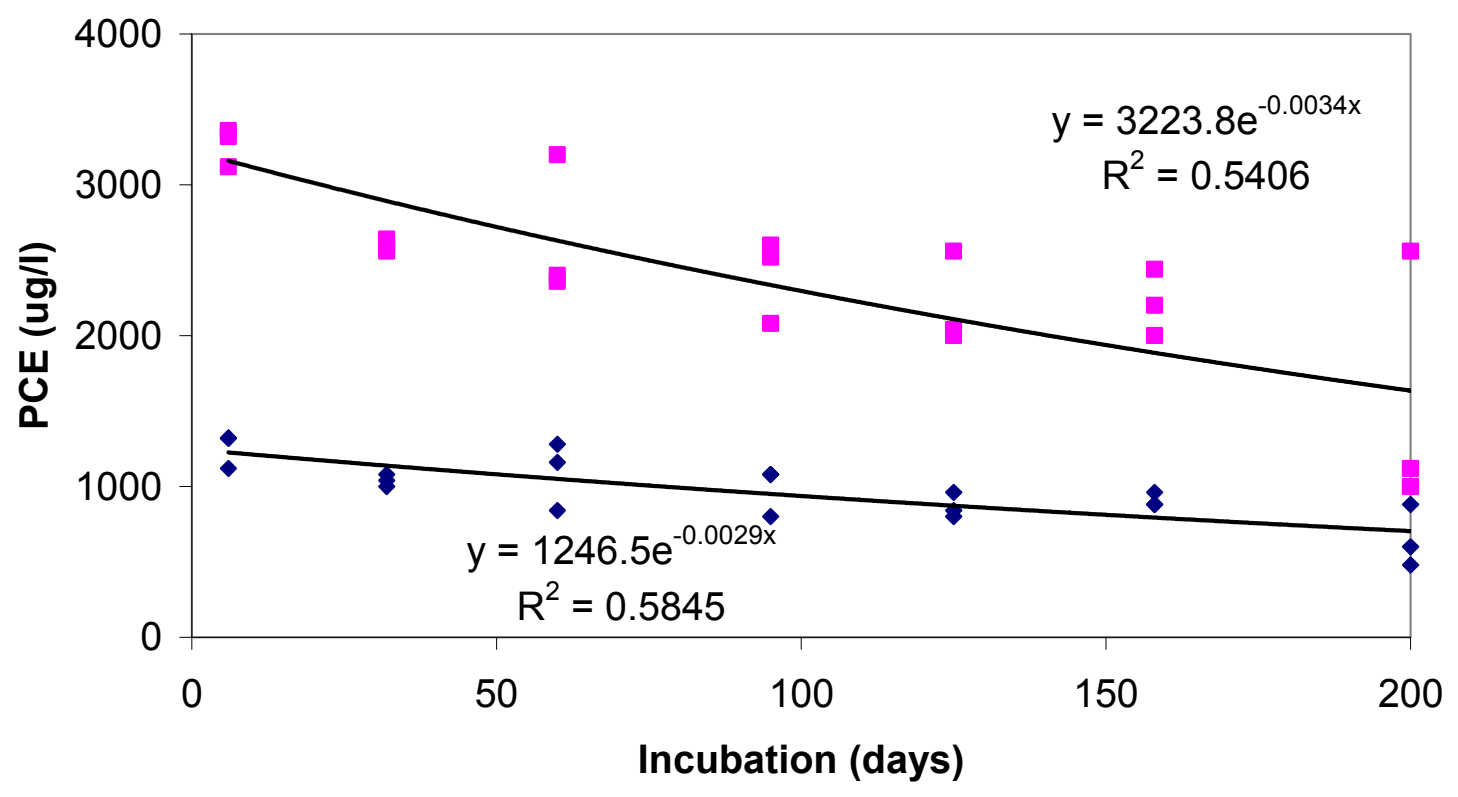

Figure 11. Plot of PCE conc. for treatments 3ES (1 mM AQDS) and 4ES (5mM AQDS). 
$\bullet 0.1 \mathrm{~g}$ lignite $=0.01 \mathrm{~g}$ lignite

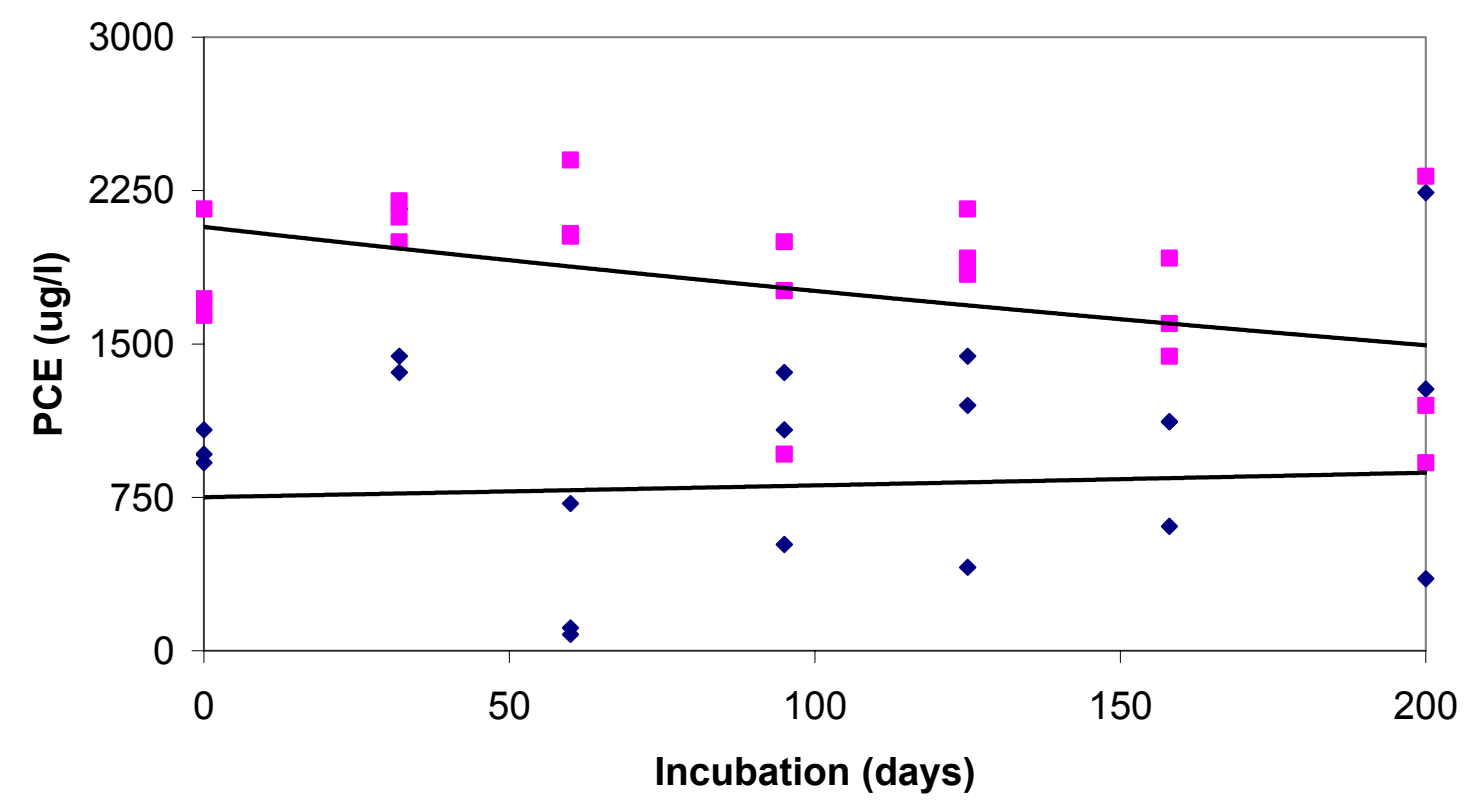

Figure 12. Plot of PCE conc. for treatments 1ES ( $0.1 \mathrm{~g}$ lignite) and 2ES (0.01g lignite).

From the data presented in Figure 11 it is unclear what mechanism drives the loss. The PCE, TCE and DCE concentration profiles for the $1 \mathrm{mMol}$ AQDS experiment (treatment 3ES) are presented in Figure 13. Similarly, the PCE, TCE and DCE concentration profiles for the 5 mMol AQDS experiment (treatment 4ES) are presented in Figure 14.

The lack of TCE initially combined with the presence of TCE later implies that the TCE is produced by at least one of the mechanisms responsible for the PCE loss. However, the fact that the TCE does not accumulate implies that there is a loss mechanism for the TCE as well. As can be seen, cDCE was not observed. The data is not shown, but neither tDCE, 1,1DCE, VC, ethene or acetylene were observed either. This implies that the mechanism responsible for the TCE loss may not go through sequential reductive dechlorination. Abiotic remediation does not go through sequential reductive dechlorination.

While the appearance of TCE suggests that the observed loss is, at least in part, due to transformation, adsorption can not be ruled out. Unfortunately, both the samples with no electron shuttle amendments (treatment 5ES) and the container control for the electron shuttles experiments (treatment 6ES) exhibited excessive noise, presumably because of a failure in the auto-pipette used for dosing the PCE. The PCE concentration profile for treatment 5ES is shown in Figure 15, and that for treatment 6ES is shown in Figure 16. 


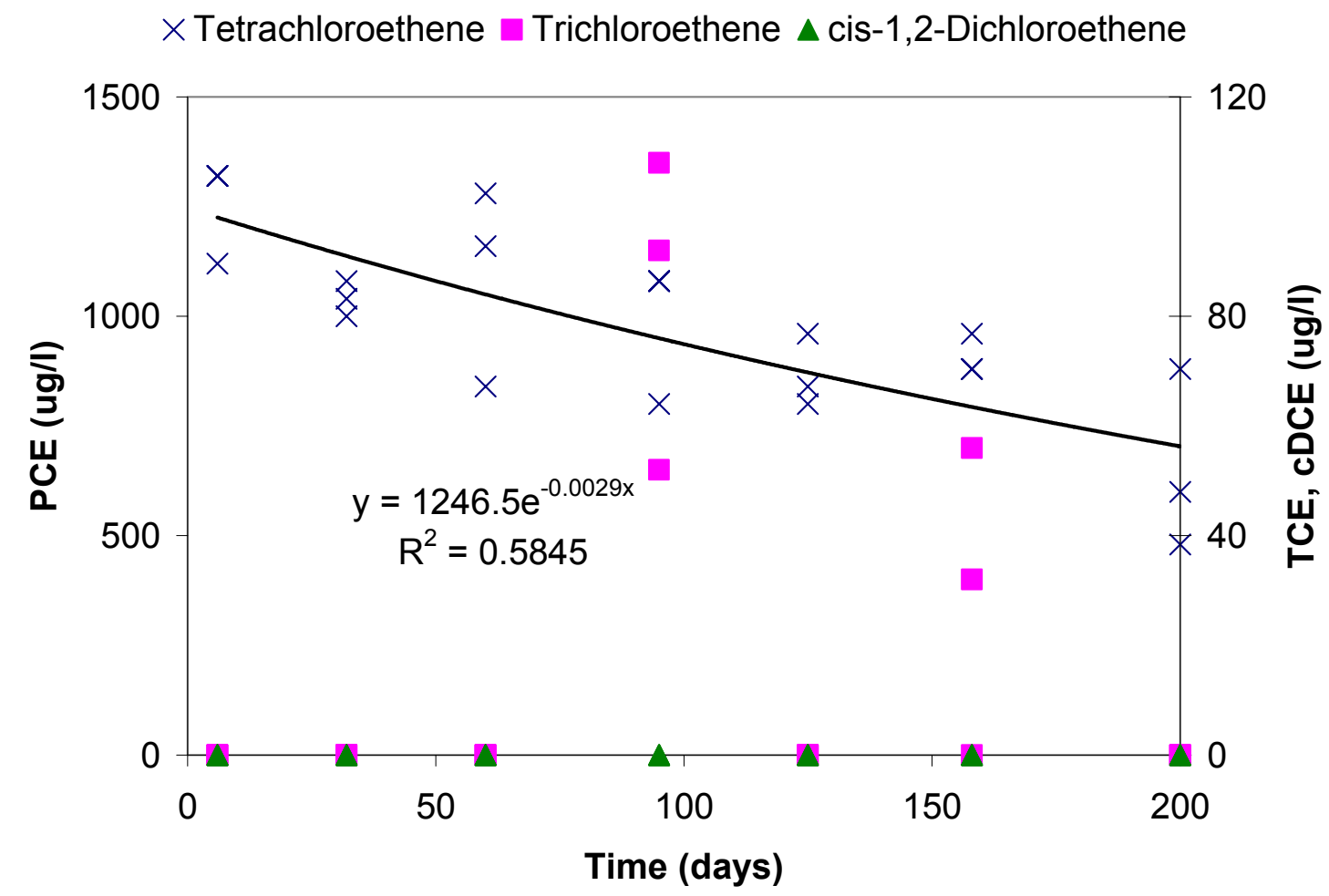

Figure 13. The PCE, TCE and DCE concentration profiles for 3ES.

\section{$5 \mathrm{mM}$ AQDS}

$\times$ Tetrachloroethene $\Delta$ cis-1,2-Dichloroethene $\square$ Trichloroethene

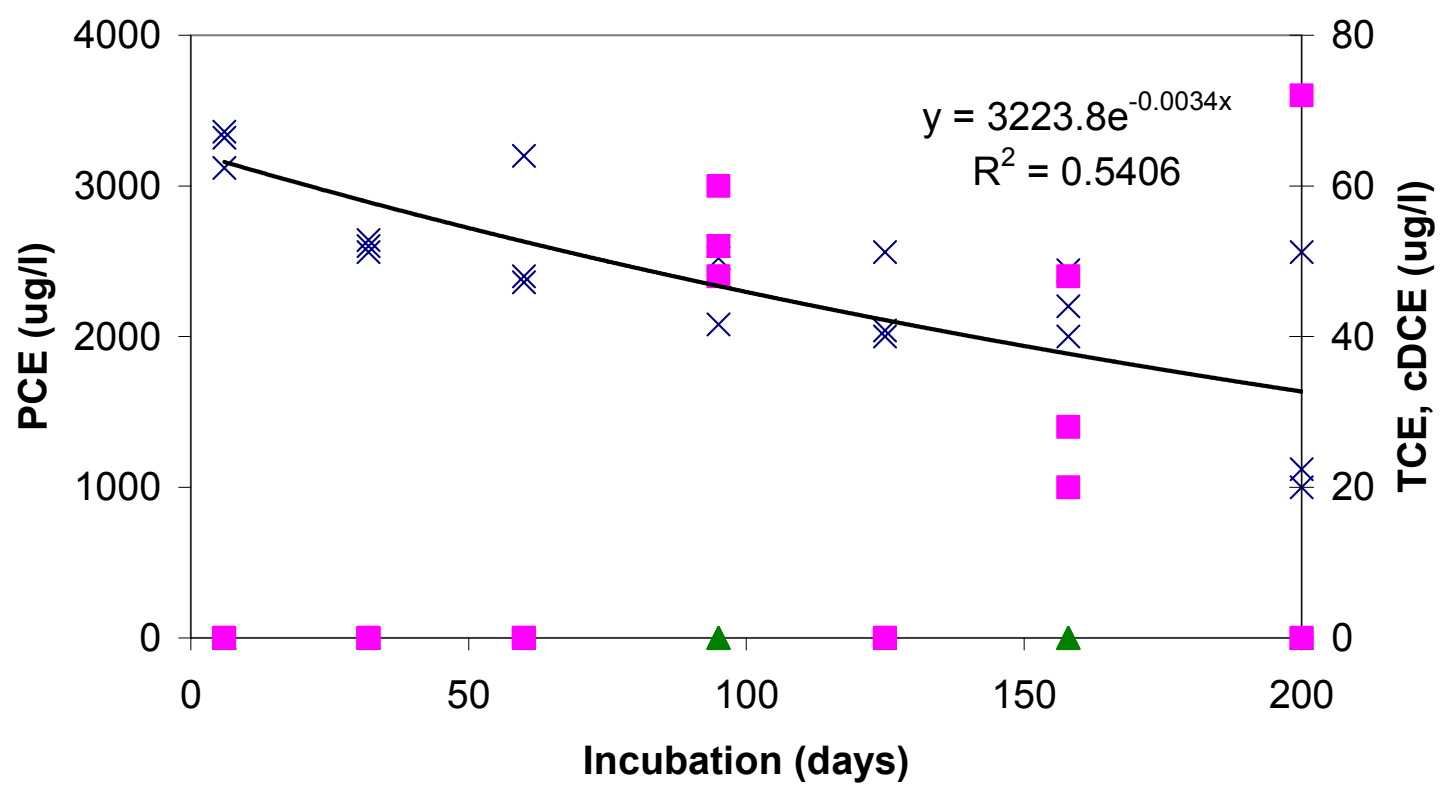

Figure 14. The PCE, TCE and DCE concentration profiles for 4ES. 
0 Shuttles, only EOS, PCE \& Soil

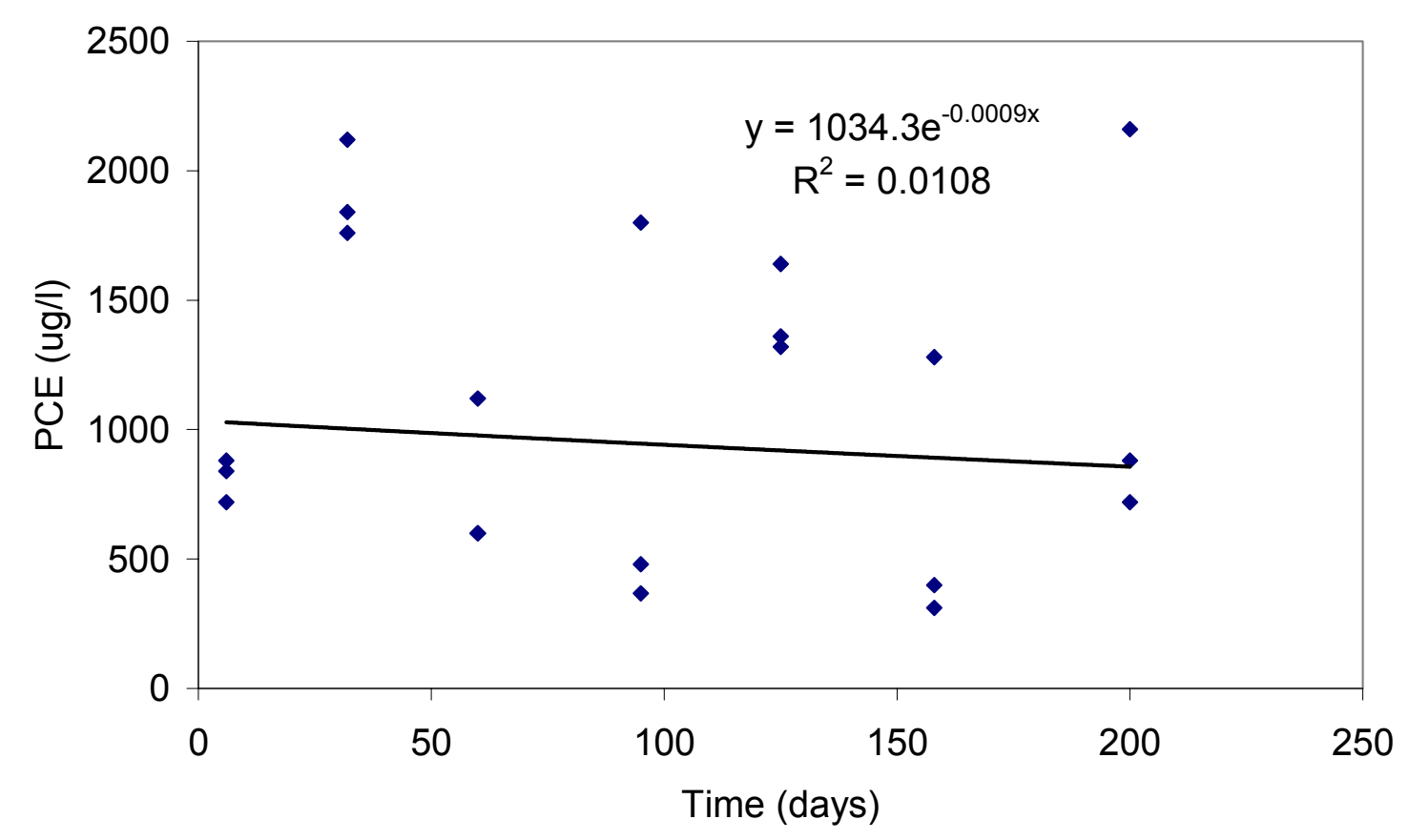

Figure 15. PCE concentration profile for 5ES.

\section{Container Control (Shuttle Expt.)}

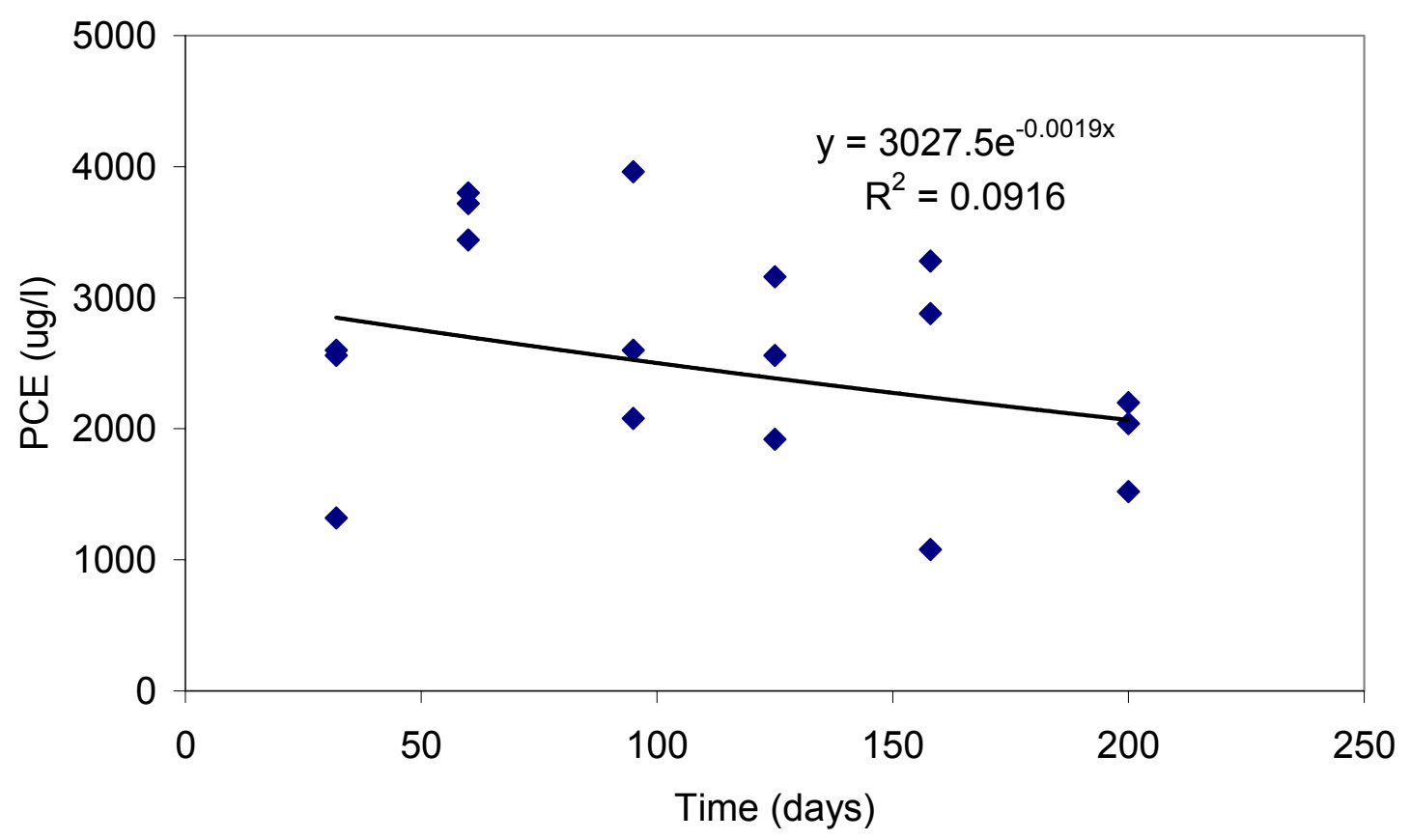

Figure 16. PCE concentration profile for 6ES. 
Despite the scatter in the data, it appears that there is a downward concentration trend in the PCE in the microcosms where AQDS was not added (treatment 5ES, Figure 15) and in the container controls (treatment 6ES, Figure 16). While the least-squares fit yields rates of loss in both the zero AQDS added microcosms (treatment 5ES) and the container controls (treatment 6ES) that are less than the rate of loss seen in the 1mMol AQDS microcosms (treatment 3ES) and $5 \mathrm{mMol}$ AQDS microcosms (treatment 4ES), the noise in the zero AQDS microcosms and in the container controls makes that conclusion statistically inappropriate. The results summarizing the statistical analysis are presented in Table 11.

Table 11. Comparison of statistical loss rates in treatments 3ES - 6ES.

\begin{tabular}{|l|l|l|l|l|}
\hline Treatment & $\begin{array}{l}\text { Mean Loss } \\
\text { Rate (per } \\
\text { year) }\end{array}$ & $\begin{array}{l}\text { Standard } \\
\text { Deviation }\end{array}$ & $\begin{array}{l}\text { Lower 90\% } \\
\text { (per year) }\end{array}$ & $\begin{array}{l}\text { Upper 90\% } \\
\text { (per year) }\end{array}$ \\
\hline $3 \mathrm{ES}$ & 1.0 & $21 \%$ & - & 0.69 \\
\hline $4 \mathrm{ES}$ & 1.2 & $19 \%$ & - & 0.79 \\
\hline $5 \mathrm{ES}$ & 0.34 & $220 \%$ & 1.6 & - \\
\hline $6 \mathrm{ES}$ & 0.70 & $79 \%$ & 1.7 & - \\
\hline
\end{tabular}

In Table 11 a regression analysis was performed assuming a two-tailed error distribution and a $90 \%$ confidence limit. This seemed appropriate since the lower boundary of a two-tailed error distribution at $90 \%$ confidence is equal to that of a single-tailed error distribution with a $95 \%$ confidence interval. To be conservative, it was assumed that the loss rate in the test experiments (3ES and 4ES) could only be slower than the mean loss rate and the loss rate in the controls (5ES and 6ES) could only be faster than the mean loss rate. With a $95 \%$ confidence, the loss rates in $3 \mathrm{ES}$ and 4ES could be explained by the loss rates in controls. However, this does not invalidate the hypothesis that the loss rate in $3 \mathrm{ES}$ and 4ES is greater than that in the controls, it simply says that this data set (i.e. the noisy controls) can not be used to support that hypothesis.

Interpretation is further complicated by the possible occurrence of both biological reductive dechlorination and abiotic dechlorination. Given the noise in the controls, it was decided to halt these experiments. Before they are resumed the tools should be better developed to measure abiotic processes and there also needs to be a way to measure the capacity of ES's. In addition, it was felt that this interpretation required a better understanding of stimulated abiotic reduction in sterilized sediment. 


\subsection{Abiotic Remediation of TCE in Sterilized, Reduced Sediment}

While it is very difficult to detect any degradation of the PCE, the data in Figure 9 makes it clear that there is some TCE produced. Further, that data suggests that the TCE degrades very rapidly. As is evident in the data presented in Figure 10, degradation occurs in both 1Fe and $2 \mathrm{Fe}$, but not in $5 \mathrm{Fe}$. Further, Figure 10 suggests that the rate of disappearance appears to be independent of the ferrous concentration, but clearly requires the sediment to be present.

With these observations it was decided to re-spike several microcosms with $\mathrm{FeCl}_{2}$ and TCE, hoping to observe the degradation of TCE more systematically.

\subsection{Method}

Fifteen microcosms from treatment $1 \mathrm{Fe}$, fifteen from treatment $2 \mathrm{Fe}$ and 8 from treatment $4 \mathrm{Fe}$ were sterilized and then amended with $\mathrm{FeCl}_{2}$ and TCE according to Table 12. Fifteen more microcosms were made up with just water and they served as container controls. The $\mathrm{FeCl}_{2}$ dose solutions were prepared as before. The TCE dose solution was prepared just as the PCE dose was prepared in the experiments detailed in the previous sections.

Table 12. Microcosm make-up for abiotic TCE degradation study.

\begin{tabular}{|c|c|c|c|c|}
\hline Treatment & Sediment & $\mathrm{FeCl}_{2}$ & TCE & Previous PCE \\
\hline $1 \mathrm{Fe}$ & Yes & $\begin{array}{l}1 \mathrm{ml}-1760 \\
\text { solution }(300 \\
\mathrm{mg} / \mathrm{l})\end{array}$ & $1 \mathrm{ml}$ & Yes \\
\hline $2 \mathrm{Fe}$ & Yes & $\begin{array}{l}1 \mathrm{ml}-535 \\
\text { solution }(100 \\
\mathrm{mg} / \mathrm{l})\end{array}$ & $1 \mathrm{ml}$ & Yes \\
\hline $4 \mathrm{Fe}$ & Yes & 0 & $1 \mathrm{ml}$ & Yes \\
\hline $6 \mathrm{Fe}^{\dagger}$ & No & 0 & $1 \mathrm{ml}$ & No \\
\hline
\end{tabular}

${ }^{\dagger}$ The microcosms for this treatment were freshly constructed at the time this experiment was prepared.

\subsection{Sampling}

Samples were collected on days 0, 7, 14, 21, 28 and 35. For the first three samplings, three microcosms were sampled from each treatment. In the fourth and fifth samplings, three microcosms from treatments $1 \mathrm{Fe}, 2 \mathrm{Fe}$ and $6 \mathrm{Fe}$ were sampled, but only one microcosm was sampled from 4Fe due to limited sample. The microcosms were sampled for TCE, cDCE and VC under aseptic conditions. Prior to sampling, the microcosms were each vortex mixed and then centrifuged to facilitate sampling. For the samples collected on days $0,7,14,21$ and 28 the sampling immediately followed the centrifuging process. For the samples collected on day 35 , the samples were vortex mixed, then centrifuged, then allowed to set overnight and sampled in the morning. 


\subsection{Results and Discussion}

The detailed results of the analyses carried out on the microcosms are presented in the Appendix, Table A36 - A39. The concentration profile of the data is shown in Figure 17.

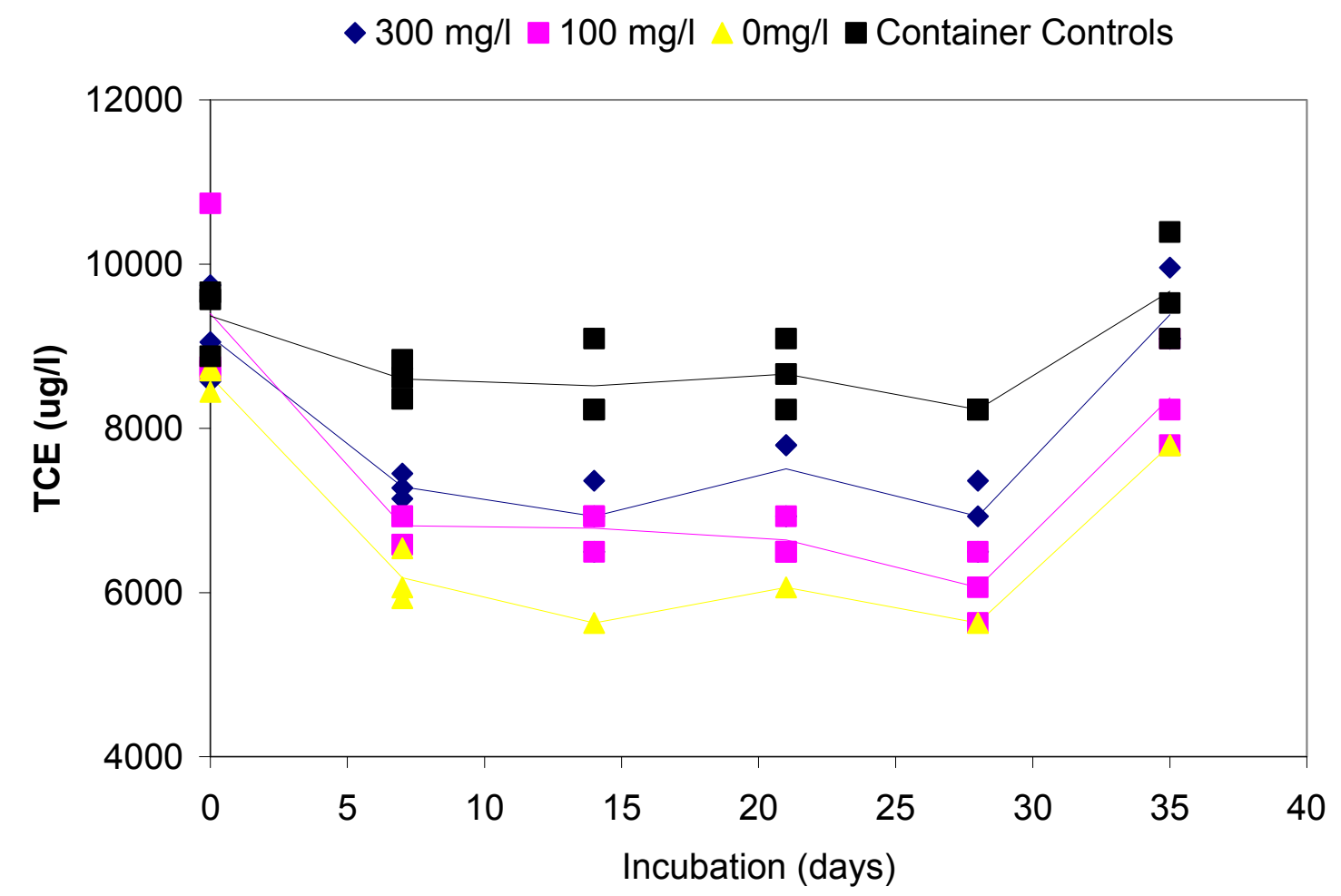

Figure 17. The concentration profile of the TCE in the sterilized sediment.

From day 0 to 28 , there appears to be some transformation in the test samples that is not matched in the container controls. When this was realized it was also realized that for the microcosm sampled for the first 28 days, sampling was performed immediately after vortex mixing and centrifuging, but for the samples collected on day 35 approximately sixteen hours elapsed between centrifuging and sampling. This apparently has a significant effect on the TCE concentration. For similarity purposes let us examine the concentration profiles without day 35. Those profiles are presented in Figure 18.

Looking at Figure 17 it appears that there is a loss of the TCE, and that loss becomes more obvious looking at Figure 18. The extent of that loss is inverse to the quantity of ferrous iron in the microcosms. This is apparent in the data presented in Table 13. 


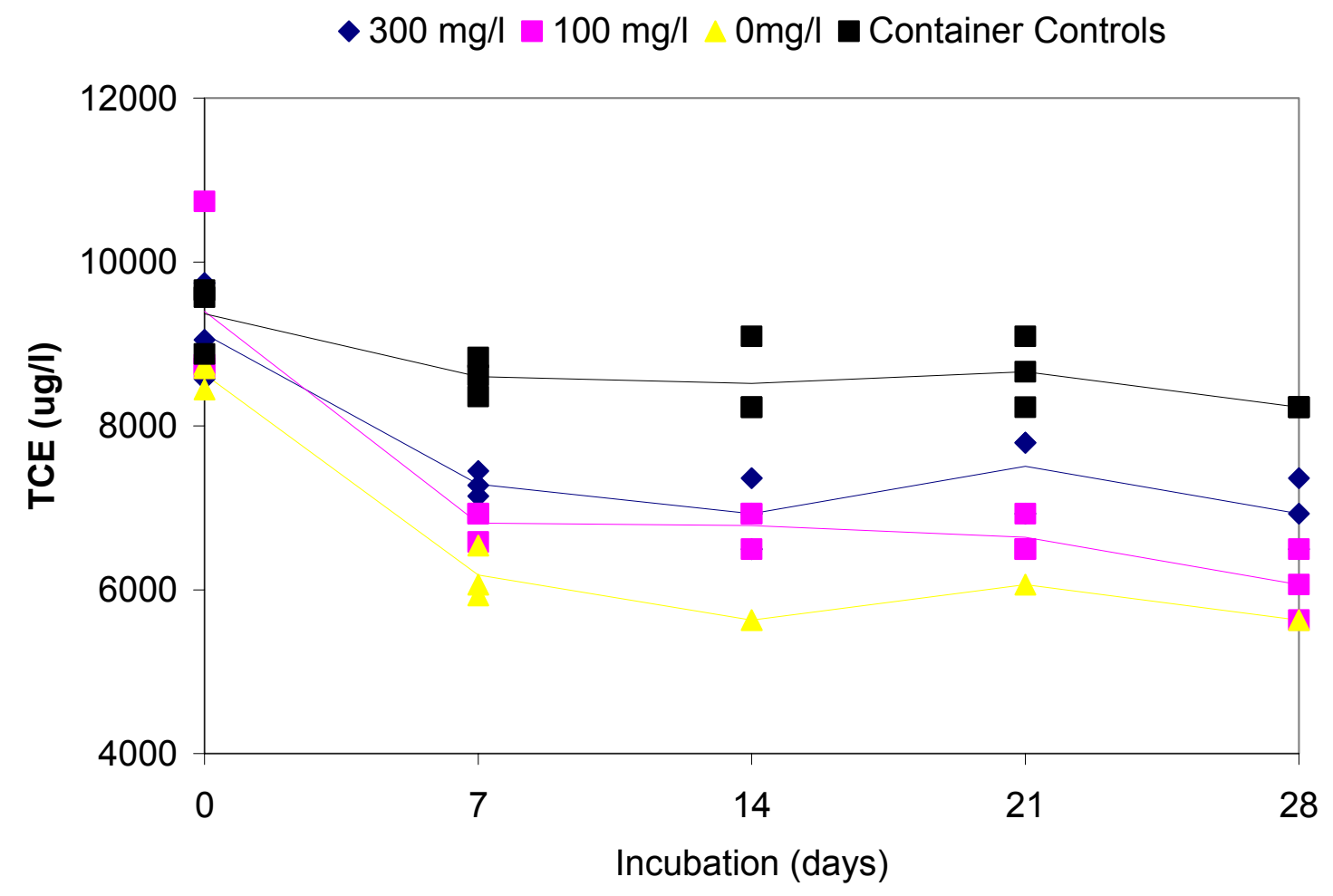

Figure 18. The concentration profile for days 0 through 28 of the TCE in the sterilized sediment.

Table 13. TCE loss between day 0 and day 7 .

\begin{tabular}{|l|l|l|l|}
\hline Treatment & $\begin{array}{l}\text { Pore Water Fe(II) } \\
(\mathbf{m g} / \mathbf{l})\end{array}$ & Average \% loss & \multicolumn{2}{l|}{$\begin{array}{l}\text { Loss rate (per } \\
\text { year) }\end{array}$} \\
\hline $1 \mathrm{Fe}$ & 300 & 20.1 & 11.7 \\
\hline $2 \mathrm{Fe}$ & 100 & 27.5 & 16.8 \\
\hline $4 \mathrm{Fe}$ & 0 & 28.4 & 17.4 \\
\hline $6 \mathrm{Fe}$ & Container Control & 8.2 & 4.4 \\
\hline
\end{tabular}

There are two possible explanations for the loss of the TCE. One possible explanation is that the initial biological reduction of the EOS added to the sediment served provided reducing power to the sediment. Between the reduction of the PCE added in the first experiment and then the reduction of the TCE added in this experiment, it appears that some time prior to day 7 the reductive power had been consumed. This observation would be much like those made by Szecsody et al (2004). This indicates that coupling the abiotic remediation to simple biological reduction of some organic substrate might be an appealing way to utilize abiotic reduction to avoid the production of unwanted daughter products and the need for specialized microorganisms. The ferrous iron may have simply occupied active surface sites, thus reducing both the capacity and rate of the degradation. This would explain why the extent of 
loss was greatest in the microcosm to which $\mathrm{FeCl}_{2}$ was not added, and why the other microcosms did not achieve the same loss even at a slower rate (Roden and Urrutia, 2002).

Another possible explanation is that the loss is due to adsorption of the TCE to the EOS and the sediment, both of which are not present in the container controls. Indeed, the data from day 35 might suggest that the loss is reversible, but without similarly collected data on the other days, that can not be examined with this data set. If the Fe(II) adsorbed to sites to which the TCE would otherwise adsorb, the extent of loss would be greatest when no $\mathrm{FeCl}_{2}$ were added and would decrease as the $\mathrm{Fe}^{+2}$ concentration increased. 


\subsection{Summary}

The literature study and the experiments done for acetylene indicate that it is stable in carefully prepared abiotic water from a $\mathrm{pH}$ of $0-14$, but there are so many other potential sinks of it, and both its oxidation and its reduction are so exoergic under a range of conditions, that acetylene, though stable in laboratory prepared, sterile aqueous solutions, is very unlikely to be stable in the environment. Further, the inability to observe acetylene in a system should not be construed as evidence that it is not being produced.

The ultimate outcome of the electron shuttle work was to indicate that this important assay should proceed through a biological reduction and not a chemical one. While this work did not culminate in a workable analytical method it did stress the importance of such a measurement and suggest a pathway for it.

On the timescales examined in the experiments conducted herein, there was no evidence of the abiotic remediation of PCE in sterilized, reduced sediment. However, by some process a small amount of PCE was transformed to TCE in both treatments $1 \mathrm{FE}$ and $2 \mathrm{Fe}$, and the loss of that TCE was very rapid, suggesting the biotic remediation of TCE in sterilized, reduced sediment experiments.

The abiotic remediation of PCE in sediment amended with an organic substrate and electron shuttles experiment suggested a loss rate of 1.7 per year with $5 \mathrm{mM}$ AQDS. However, experimental problems occurred with the preparation of the control microcosms that make that conclusion statistically invalid. In addition, it is unclear what mechanism drives that loss. Adsorption is unlikely because that should level off, but a steady loss was seen in this experiment. However, this could be absolutely ruled out through the use of a killed control. The loss could also be driven by biological sequential reductive dechlorination, by biological sequential reductive dechlorination followed by oxidation of DCE (Bradley, Chapelle and Lovely, 1998) or by abiotic remediation or by some combination of all three. The only daughter product observed was TCE, and it did not accumulate. Another tool for unraveling degradation mechanisms has become available and that is compound specific isotopic analysis (CSIA). While it was not used in this experiment, it would be of great value if this experiment were repeated.

The experiments conducted so far are promising, but similar experiments, with additional controls and with use of CSIA, would need to be conducted. There is no need to test multiple electron shuttles in those experiments. The TES analysis should be developed first and it should be used to find appropriate test candidates.

The abiotic remediation of TCE in sterilized, reduced sediment experiments can not be used to discern between adsorption, a potentially reversible mechanism, and contaminant destruction via abiotic remediation. The suggestion that abiotic remediation can be stimulated through the addition of organic substrates is appealing because it minimizes potential formation of toxic intermediate products and eliminates the need for specialized microorganisms. However, it would take another experiment to definitively prove it. In that experiment there should be a control sediment that was spiked with EOS and then 
immediately killed. Since it was shown that the loss was not driven by the addition of $\mathrm{FeCl}_{2}$ but instead possibly by the reducing power of the sediment, there is no need to spike $\mathrm{FeCl}_{2}$ at all or to prepare different microcosms where it is spiked at different levels. Instead three sets of test microcosms should be prepared, each of which were allowed to incubate for different times between EOS addition and sterilization.

The promise of abiotic remediation is strong, and there seems to be potential for stimulating it through the addition of electron shuttles and a long acting substrate such as EOS. To make this technology employable at field scale a TES measurement must be developed, and this work suggested how that might be done. This work also studied acetylene and found it to be an unreliable indicator of the presence of abiotic remediation. It is hoped that CSIA provides a more useful tool for indicating abiotic remediation. 


\section{References}

Bradley, P. M. Chapelle, F. H. and Lovely, D. R. 1998. "Humic Acids as Electron Acceptors for the Anaerobic Microbial Oxidation of Vinyl Chloride and Dichloroethene." App. Environ. Microbiol. Vol. 64, pp 3102-3105.

Braga, R. J., Starr, J. L. and Parkin, T. B. 1997. "Acetylene Transport In Shallow Groundwater for Denitrification Rate Measurement.” J. Environ. Qual. Vol. 26. pp. 15241530 .

Culbertson, C.W., A. J. B. Zehnder and R. S. Oremland. 1981. "Anaerobic Oxidation of Acetylene by Estuarine Sediments and Enrichment Cultures.” App. Envir. Microbiol. Vol. 41. p. 396.

Field, J. A., F. J. Cervantes, F. P. Van der Zee and G. Lettinga. 2000. "Role of quinones in the biodegradation of priority pollutants: a review." Water Sci. Tecnol. Vol. 42. pp. 215-222.

Kanner, D. and R. Bartha. 1979. "Growth of Nocardia rhodocrus on acetylene gas." J. Bacteriol. Vol. 139. pp. 225-230.

Kanner, D. and R. Bartha. 1982. "Metabolism of acetylene by Nocardia rhodocrus." J. Bacteriol. Vol. 150. pp. 989-992.

Nurmi, J. T. and Tratnyek, P. G. 2002a. "Electrochemical Properties of Natural Organic Matter (NOM), Fractions of NOM, and Model Biogeochemical Electron Shuttles." Environ. Sci. Technol. Vol 36. pp. 617-624.

Nurmi, J. T. and Tratnyek, P. G. 2002b. "Voltammetric Investigations of Natural Organic Matter." Proceedings of the $20^{\text {th }}$ Anniversary Conference of the International Humic Substances Society (IHSS). July 21-26, Boston, MA. pp. 58-60.

Perlinger, J. A., W. Angst and R. P. Schwarzenbach. 1996. "Kinetics of the Reduction of Juglone in Solutions Containing Hydrogen Sulfide.” Environ. Sci. Tecnol. Vol. 30. pp. 34083417.

Perlinger, J. A.; Kalluri, V. M.; Venkatapathy, R.; Angst, W. 2002. "Addition of Hydrogen Sulfide to Juglone." Environ. Sci. Tecnol. Vol. 36. pp. 2663-2669.

Roden, E. E., and Urrutia M. M. 2002. "Influence of Biogenic Fe(II) on Bacterial Crystalline Fe(III) Oxide Reduction.” Geomicrobiol. J. Vol. 19. pp. 209-251.

Szecosdy, J. E., J. S. Fruchter, M. D. Williams, V. R. Vermeul and D. Skarlew. 2004. Environ. Sci. Tecnol. Vol. 38. pp. 4656-4663.

USEPA. 1996. "Test Methods for Evaluating Solid Waste: Third Edition, Final Update III." SW-846. 
USEPA. 2002. "Workshop on Monitoring Oxidation-Reduction Processes for Ground-water Restoration”. EPA/600/R-02/002.

Watanabe, I and M. R. deGuzman. 1980. "Effect of nitrate on acetylene disappearance from anaerobic soil." Soil Biol. Biochem. Vol. 12. pp. 193-194.

Yeomans, J. C. and E. G. Beauchamp. 1982. "Acetylene as a possible substrate in the denitrification process.” Can. J. Soil Sci. Vol. 62. pp. 139-144. 
WSRC-STI-2006-00189, Rev. 0

September 19, 2006

Page 43 of 82

Appendix 
WSRC-STI-2006-00189, Rev. 0

September 19, 2006

Page 44 of 82

Table A1. Data for study of stability of LHC gases in sample vials.

\begin{tabular}{|c|c|c|c|c|c|c|c|}
\hline \multirow[t]{2}{*}{ Analyte(s) } & \multirow[t]{2}{*}{ Units } & \multicolumn{6}{|l|}{ Sampling Day } \\
\hline & & 1 & 3 & 10 & 15 & 21 & 28 \\
\hline HYDROGEN-A & PPMV & 9.435 & 10.596 & 7.958 & 9.046 & 10.157 & 9.341 \\
\hline HYDROGEN-B & PPMV & 9.071 & 10.018 & 7.897 & 9.271 & 10.222 & 9.746 \\
\hline HYDROGEN-C & PPMV & 10.096 & 9.683 & 7.951 & 9.090 & 9.599 & 9.785 \\
\hline METHANE-A & PPMV & 122.785 & 123.595 & 123.160 & 126.655 & 128.884 & 126.916 \\
\hline METHANE-B & PPMV & 122.413 & 123.359 & 123.264 & 128.380 & 127.588 & 130.181 \\
\hline METHANE-C & PPMV & 123.846 & 122.287 & 123.050 & 126.137 & 127.052 & 127.057 \\
\hline ETHANE-A & PPMV & 39.465 & 40.451 & 38.710 & 38.285 & 39.358 & 37.250 \\
\hline ETHANE-B & PPMV & 39.352 & 40.050 & 38.484 & 38.579 & 39.212 & 38.671 \\
\hline ETHANE-C & PPMV & 39.786 & 39.808 & 38.711 & 38.198 & 39.020 & 37.937 \\
\hline ETHENE-A & PPMV & 39.364 & 40.395 & 38.519 & 38.124 & 39.281 & 37.096 \\
\hline ETHENE-B & PPMV & 39.233 & 39.973 & 38.313 & 38.353 & 39.148 & 38.376 \\
\hline ETHENE-C & PPMV & 39.747 & 39.769 & 38.542 & 38.003 & 38.904 & 37.681 \\
\hline PROPANE-A & PPMV & 38.826 & 39.376 & 35.881 & 35.909 & 36.581 & 33.650 \\
\hline PROPANE-B & PPMV & 38.621 & 38.944 & 35.610 & 36.148 & 36.627 & 35.514 \\
\hline PROPANE-C & PPMV & 39.019 & 38.760 & 36.013 & 35.520 & 36.374 & 34.756 \\
\hline PROPENE-A & PPMV & 38.429 & 38.828 & 34.040 & 33.793 & 34.821 & 30.758 \\
\hline PROPENE-B & PPMV & 38.116 & 38.400 & 33.660 & 34.217 & 34.898 & 32.856 \\
\hline PROPENE-C & PPMV & 38.632 & 38.101 & 34.301 & 33.460 & 34.578 & 32.057 \\
\hline ISO-BUTANE-A & PPMV & 38.724 & 39.211 & 35.592 & 35.647 & 36.567 & 33.417 \\
\hline ISO-BUTANE-B & PPMV & 39.606 & 38.792 & 35.336 & 36.014 & 36.695 & 35.418 \\
\hline ISO-BUTANE-C & PPMV & 38.772 & 38.597 & 35.900 & 35.342 & 36.397 & 34.503 \\
\hline N-BUTANE-A & PPMV & 38.266 & 38.584 & 34.418 & 34.298 & 34.495 & 29.760 \\
\hline N-BUTANE-B & PPMV & 37.802 & 37.924 & 33.395 & 34.424 & 34.844 & 33.328 \\
\hline N-BUTANE-C & PPMV & 38.489 & 37.863 & 34.492 & 33.765 & 34.397 & 32.313 \\
\hline
\end{tabular}


WSRC-STI-2006-00189, Rev. 0

Table A2. Data for study of stability of LHC gases in sample vials (continued).

\begin{tabular}{|c|c|c|c|c|c|c|}
\hline \multirow[t]{2}{*}{ Analyte(s) } & \multirow[t]{2}{*}{ Units } & \multicolumn{5}{|c|}{ Sampling Day } \\
\hline & & 35 & 42 & 46 & 51 & 60 \\
\hline HYDROGEN-A & PPMV & 9.764 & 9.877 & 10.589 & 11.256 & 11.203 \\
\hline HYDROGEN-B & PPMV & 9.680 & 9.643 & 10.736 & 10.748 & 11.489 \\
\hline HYDROGEN-C & PPMV & 9.422 & 9.940 & 10.502 & 10.985 & 10.788 \\
\hline METHANE-A & PPMV & 126.033 & 124.898 & 125.554 & 121.373 & 124.675 \\
\hline METHANE-B & PPMV & 126.835 & 122.412 & 125.805 & 119.321 & 125.036 \\
\hline METHANE-C & PPMV & 126.639 & 125.257 & 119.453 & 116.938 & 123.749 \\
\hline ETHANE-A & PPMV & 37.329 & 38.567 & 37.986 & 36.643 & 37.697 \\
\hline ETHANE-B & PPMV & 37.793 & 37.102 & 38.214 & 35.813 & 37.323 \\
\hline ETHANE-C & PPMV & 37.851 & 38.216 & 35.536 & 35.257 & 37.277 \\
\hline ETHENE-A & PPMV & 37.253 & 38.348 & 37.895 & 36.472 & 37.635 \\
\hline ETHENE-B & PPMV & 37.605 & 37.032 & 38.092 & 35.773 & 37.451 \\
\hline ETHENE-C & PPMV & 37.689 & 38.193 & 35.585 & 35.080 & 37.265 \\
\hline PROPANE-A & PPMV & 33.020 & 34.013 & 34.976 & 33.124 & 34.850 \\
\hline PROPANE-B & PPMV & 34.049 & 32.138 & 35.210 & 31.712 & 33.645 \\
\hline PROPANE-C & PPMV & 34.229 & 33.133 & 31.919 & 31.668 & 34.395 \\
\hline PROPENE-A & PPMV & 30.306 & 31.159 & 32.796 & 30.803 & 32.892 \\
\hline PROPENE-B & PPMV & 31.604 & 29.136 & 33.072 & 29.111 & 31.363 \\
\hline PROPENE-C & PPMV & 31.858 & 30.166 & 29.729 & 29.335 & 32.534 \\
\hline ISO-BUTANE-A & PPMV & 32.686 & 33.956 & 34.963 & 33.138 & 34.807 \\
\hline ISO-BUTANE-B & PPMV & 34.056 & 31.873 & 35.239 & 31.631 & 33.578 \\
\hline ISO-BUTANE-C & PPMV & 34.209 & 32.853 & 31.608 & 31.635 & 34.458 \\
\hline N-BUTANE-A & PPMV & 29.167 & 31.090 & 32.122 & 30.005 & 31.556 \\
\hline N-BUTANE-B & PPMV & 31.602 & 28.037 & 32.629 & 27.032 & 28.286 \\
\hline N-BUTANE-C & PPMV & 31.764 & 28.596 & 27.804 & 28.633 & 31.161 \\
\hline
\end{tabular}


WSRC-STI-2006-00189, Rev. 0

Table A. 3 General data for treatment $1 \mathrm{Fe}$ microcosms and Ferrous concentrations.

$\begin{array}{lllll}\text { Sample ID } & \text { incubation (days) } & \text { lab project } & \text { Ferrous Iron (mg/l) } & \text { Solids (\%) } \\ \text { SRS 342 } & 2 & \text { P0507166 } & 70 & 53 \\ \text { SRS 343 } & 2 & \text { P0507166 } & 60 & 50 \\ \text { SRS 348 } & 2 & \text { P0507166 } & 60 & 44 \\ \text { SRS 307 } & 7 & \text { P0507294 } & 55 & 22 \\ \text { SRS 315 } & 7 & \text { P0507294 } & 49.5 & 41 \\ \text { SRS 320 } & 7 & \text { P0507294 } & 60 & 46 \\ \text { SRS 321 } & 14 & \text { P0507424 } & 55 & 50 \\ \text { SRS 326 } & 14 & \text { P0507424 } & 50 & 38 \\ \text { SRS 341 } & 14 & \text { P0507424 } & 55 & 43 \\ \text { SRS 333 } & 21 & \text { P0508157 } & 49 & 40 \\ \text { SRS 340 } & 21 & \text { P0508157 } & 55 & 39 \\ \text { SRS 346 } & 21 & \text { P0508157 } & 55 & 46 \\ \text { SRS 304 } & 28 & \text { P0508189 } & 55 & 45 \\ \text { SRS 317 } & 28 & \text { P0508189 } & 55 & 44 \\ \text { SRS 334 } & 28 & \text { P0508189 } & 55 & 41 \\ \text { SRS 331 } & 41 & \text { P0508393 } & 63 & 35 \\ \text { SRS 335 } & 41 & \text { P0508393 } & 48 & 45 \\ \text { SRS 347 } & 41 & \text { P0508393 } & 60 & 47 \\ \text { SRS 332 } & 54 & \text { P0509094 } & 60 & 48 \\ \text { SRS 337 } & 54 & \text { P0509094 } & 55 & 58 \\ \text { SRS 338 } & 54 & \text { P0509094 } & 55 & 50 \\ \text { SRS 302 } & 84 & \text { P0510066 } & 60 & 51 \\ \text { SRS 322 } & 84 & \text { P0510066 } & 60 & \end{array}$


WSRC-STI-2006-00189, Rev. 0

September 19, 2006

Page 47 of 82

Table A.4 Dissolved gas concentrations (ug/l) for Treatment 1Fe microcosms.

$\begin{array}{lllllllll}\text { Sample ID } & \text { Acetylene } & \text { Ethane } & \text { Ethene } & \text { iso-Butane } & \text { Methane } & \text { n-Butane } & \text { Propane } & \text { Propene } \\ \text { SRS 342 } & 0 & 10.8 & 1.24 & 3.72 & 48 & 6.4 & 1.76 & 2.96 \\ \text { SRS 343 } & 0 & 64 & 0 & 0 & 18.8 & 0 & 0 & 0 \\ \text { SRS 348 } & 0 & 68 & 0 & 0 & 18.4 & 0 & 0 & 0 \\ \text { SRS 307 } & 0 & 12 & 0 & 0 & 11.2 & 0 & 0 & 0 \\ \text { SRS 315 } & 0 & 16.4 & 0.44 & 0 & 14.4 & 0 & 0 & 0 \\ \text { SRS 320 } & 0 & 22 & 0.44 & 0 & 14.8 & 0 & 0 & 0 \\ \text { SRS 321 } & 0 & 72 & 0.56 & 1 & 25.2 & 2.32 & 1.16 & 1.32 \\ \text { SRS 326 } & 0 & 72 & 0.24 & 0 & 18.4 & 0.92 & 0.52 & 0 \\ \text { SRS 341 } & 0 & 80 & 0 & 0 & 19.2 & 0 & 0.56 & 0 \\ \text { SRS 333 } & 0 & 0 & 0 & 0 & 0 & 0 & 0 & 0 \\ \text { SRS 340 } & 0 & 8 & 0.52 & 0 & 7.6 & 0 & 0 & 0 \\ \text { SRS 346 } & 0 & 9.6 & 0.56 & 0 & 8.8 & 0 & 0 & 0 \\ \text { SRS 304 } & 0 & 18.8 & 2.16 & 0 & 40 & 0 & 0 & 0 \\ \text { SRS 317 } & 0 & 19.2 & 1.36 & 0 & 30.4 & 0 & 0 & 0 \\ \text { SRS 334 } & 0 & 20 & 1.24 & 0 & 29.6 & 0 & 0 & 0 \\ \text { SRS 331 } & 0 & 6 & 14 & 1.24 & 88 & 3.72 & 2 & 2.48 \\ \text { SRS 335 } & 0 & 37.6 & 3.32 & 0 & 18.4 & 0 & 0 & 0 \\ \text { SRS 347 } & 0 & 35.2 & 3.04 & 0 & 20.4 & 0 & 0 & 0 \\ \text { SRS 332 } & 0 & 13.6 & 4.4 & 1.84 & 104 & 4.4 & 2.44 & 2.12 \\ \text { SRS 337 } & 0 & 16.4 & 1.68 & 0 & 36 & 0.68 & 0 & 0.4 \\ \text { SRS 338 } & 0 & 15.6 & 2.52 & 0 & 48 & 0.8 & 0.6 & 0.72 \\ \text { SRS 302 } & 0 & 4.8 & 0 & 0 & 3.52 & 0 & 0 & 0 \\ \text { SRS 322 } & 0 & 5.6 & 0 & 0 & 4 & 0 & 0 & 0 \\ \text { SRS 330 } & 0 & 6.4 & 0.24 & 0 & 4.8 & 0 & 0 & 0\end{array}$


WSRC-STI-2006-00189, Rev. 0

September 19, 2006

Page 48 of 82

Table A.5 Chlorinated ethene (ug/l) and common ion concentrations ( $\mathrm{mg} /$ ) for Treatment 1Fe microcosms.

$\begin{array}{lllllllllll}\text { Sample ID } & 11 D C E & \text { cDCE } & \text { PCE } & \text { tDCE } & \text { TCE } & \text { VC } & \text { Chloride } & \text { Nitrate } & \text { Nitrite } & \text { Sulfate } \\ \text { SRS 342 } & 0 & 0 & 3080 & 0 & 0 & 0 & 150 & 0 & 0 & 15 \\ \text { SRS 343 } & 0 & 0 & 2880 & 0 & 0 & 0 & 160 & 0 & 0 & 16 \\ \text { SRS 348 } & 0 & 0 & 2720 & 0 & 0 & 0 & 160 & 0 & 0 & 16 \\ \text { SRS 307 } & 0 & 0 & 2880 & 0 & 0 & 0 & 150 & 4.9 & 0 & 16 \\ \text { SRS 315 } & 0 & 0 & 3560 & 0 & 0 & 0 & 150 & 0 & 0 & 16 \\ \text { SRS 320 } & 0 & 0 & 3120 & 0 & 0 & 0 & 120 & 0 & 0 & 17 \\ \text { SRS 321 } & 0 & 0 & 2560 & 0 & 76 & 0 & 150 & 0 & 0 & 17 \\ \text { SRS 326 } & 0 & 0 & 2440 & 0 & 72 & 0 & 140 & 5.6 & 0 & 29 \\ \text { SRS 341 } & 0 & 0 & 2280 & 0 & 60 & 0 & 160 & 0 & 0 & 17 \\ \text { SRS 333 } & 0 & 12 & 2160 & 0 & 48 & 0 & 120 & 1.1 & 0 & 4.2 \\ \text { SRS 340 } & 0 & 0 & 2040 & 0 & 40 & 0 & 110 & 1 & 0 & 3 \\ \text { SRS 346 } & 0 & 0 & 1920 & 0 & 40 & 0 & 130 & 0 & 0 & 5 \\ \text { SRS 304 } & 0 & 12 & 2760 & 0 & 20 & 0 & 110 & 0 & 0 & 0 \\ \text { SRS 317 } & 0 & 0 & 2520 & 0 & 16 & 0 & 120 & 0 & 0 & 1.2 \\ \text { SRS 334 } & 0 & 0 & 2520 & 0 & 16 & 0 & 110 & 0.09 & 0 & 0 \\ \text { SRS 331 } & 0 & 0 & 2320 & 0 & 12 & 0 & 99 & 0 & 0 & 14 \\ \text { SRS 335 } & 0 & 0 & 2320 & 0 & 0 & 0 & 130 & 0 & 0 & 14 \\ \text { SRS 347 } & 0 & 0 & 2360 & 0 & 0 & 0 & 130 & 9.8 & 0 & 17 \\ \text { SRS 332 } & 0 & 0 & 2840 & 0 & 0 & 0 & 150 & 4.8 & 3.1 & 0 \\ \text { SRS 337 } & 0 & 0 & 2800 & 0 & 0 & 0 & 130 & 5.2 & 3.6 & 15 \\ \text { SRS 338 } & 0 & 0 & 2920 & 0 & 0 & 0 & 160 & 0 & 3.1 & 0 \\ \text { SRS 302 } & 0 & 0 & 2360 & 0 & 0 & 0 & 88 & 0 & 0 & 0 \\ \text { SRS 322 } & 0 & 0 & 2280 & 0 & 0 & 0 & 82 & 9.4 & 0 & 0 \\ \text { SRS 330 } & 0 & 0 & 1960 & 0 & 0 & 0 & 95 & 0 & 0 & 29\end{array}$


Table A.6 General data for treatment $2 \mathrm{Fe}$ microcosms and Ferrous concentrations.

$\begin{array}{lllll}\text { Sample ID } & \text { incubation (days) } & \text { lab project } & \text { Ferrous Iron }(\mathrm{mg} / \mathrm{l}) & \text { Solids (\%) } \\ \text { SRS 352 } & 2 & \text { P0507166 } & 8.5 & 49 \\ \text { SRS 359 } & 2 & \text { P0507166 } & 8 & 34 \\ \text { SRS 385 } & 2 & \text { P0507166 } & 8.5 & 49 \\ \text { SRS 358 } & 7 & \text { P0507294 } & 8.5 & 51 \\ \text { SRS 371 } & 7 & \text { P0507294 } & 8 & 51 \\ \text { SRS 373 } & 7 & \text { P0507294 } & 4 & 56 \\ \text { SRS 362 } & 14 & \text { P0507424 } & 8 & 38 \\ \text { SRS 370 } & 14 & \text { P0507424 } & 7 & 47 \\ \text { SRS 393 } & 14 & \text { P0507424 } & 6 & 47 \\ \text { SRS 350 } & 21 & \text { P0508157 } & 8 & 39 \\ \text { SRS 354 } & 21 & \text { P0508157 } & 7.5 & 50 \\ \text { SRS 375 } & 21 & \text { P0508157 } & 7 & 48 \\ \text { SRS 363 } & 28 & \text { P0508189 } & 7.5 & 39 \\ \text { SRS 387 } & 28 & \text { P0508189 } & 6.5 & 40 \\ \text { SRS 392 } & 28 & \text { P0508189 } & 5.5 & 51 \\ \text { SRS 351 } & 41 & \text { P0508393 } & 8 & 42 \\ \text { SRS 379 } & 41 & \text { P0508393 } & 4 & 37 \\ \text { SRS 388 } & 41 & \text { P0508393 } & 8.5 & 39 \\ \text { SRS 361 } & 54 & \text { P0509094 } & 8 & 43 \\ \text { SRS 372 } & 54 & \text { P0509094 } & 9 & 58 \\ \text { SRS 378 } & 54 & \text { P0509094 } & 11 & 46 \\ \text { SRS 369 } & 84 & \text { P0510066 } & 7 & 47 \\ \text { SRS 390 } & 84 & \text { P0510066 } & 5 & 49 \\ \text { SRS 394 } & 84 & \text { P0510066 } & 7 & 52\end{array}$


WSRC-STI-2006-00189, Rev. 0

September 19, 2006

Page 50 of 82

Table A.7 Dissolved gas concentrations (ug/l) for Treatment 2Fe microcosms.

\begin{tabular}{|c|c|c|c|c|c|c|c|c|}
\hline Sample ID & Acetylene & Ethane & Ethene & iso-Butane & Methane & n-Butane & Propane & Propene \\
\hline SRS 352 & 0 & 72 & 0.24 & 0 & 18.4 & 0 & 0 & 0 \\
\hline SRS 359 & 0 & 76 & 0 & 0 & 21.2 & 0 & 0 & 0 \\
\hline SRS 385 & 0 & 72 & 0 & 0 & 19.6 & 0 & 0 & 0 \\
\hline SRS 358 & 0 & 11.6 & 0.4 & 0 & 8 & 0 & 0 & 0 \\
\hline SRS 371 & 0 & 14.8 & 0.32 & 0 & 10.4 & 0 & 0 & 0 \\
\hline SRS 373 & 0 & 19.2 & 0.36 & 0 & 12.8 & 0 & 0 & 0 \\
\hline SRS 362 & 0 & 23.2 & 0.32 & 0 & 8.4 & 0 & 0 & 0.52 \\
\hline SRS 370 & 0 & 25.2 & 0.28 & 0 & 8.4 & 0 & 0 & 0 \\
\hline SRS 393 & 0 & 28 & 0.24 & 0 & 8.8 & 0 & 0 & 0 \\
\hline SRS 350 & 0 & 8.4 & 0.36 & 0 & 6.8 & 0 & 0 & 0 \\
\hline SRS 354 & 0 & 10 & 0.32 & 0 & 8 & 0 & 0 & 0 \\
\hline SRS 375 & 0 & 11.2 & 0.36 & 0 & 7.6 & 0 & 0 & 0 \\
\hline SRS 363 & 0 & 20.4 & 0.96 & 0 & 25.6 & 0 & 0 & 0 \\
\hline SRS 387 & 0 & 25.6 & 0.92 & 0 & 25.6 & 0 & 0 & 0 \\
\hline SRS 392 & 0 & 27.6 & 0.88 & 0 & 25.2 & 0 & 0 & 0 \\
\hline SRS 351 & 0 & 38 & 3 & 0 & 17.6 & 0 & 0.48 & 0 \\
\hline SRS 379 & 0 & 80 & 6.4 & 0 & 34.4 & 0 & 0 & 0 \\
\hline SRS 388 & 0 & 40 & 2.72 & 0 & 17.2 & 0 & 0 & 0 \\
\hline SRS 361 & 0 & 20 & 1.56 & 0 & 30 & 0 & 0.52 & 0 \\
\hline SRS 372 & 0 & 17.6 & 1.2 & 0 & 20.8 & 0 & 0 & 0 \\
\hline SRS 378 & 0 & 24 & 1.4 & 0 & 29.6 & 0 & 0 & 0 \\
\hline SRS 369 & 0 & 2.52 & 0.24 & 0 & 5.6 & 0 & 0 & 0 \\
\hline SRS 390 & 0 & 7.2 & 7.6 & 2.76 & 44 & 8 & 3.6 & 4.4 \\
\hline SRS 394 & 0 & 6.4 & 2.64 & 0.92 & 11.2 & 1.04 & 0.84 & 1.04 \\
\hline
\end{tabular}


WSRC-STI-2006-00189, Rev. 0

Table A.8 Chlorinated ethene (ug/l) and common ion concentrations (mg/l) for Treatment $2 \mathrm{Fe}$ microcosms.

$\begin{array}{lllllllllll}\text { Sample ID } & 11 D C E & \text { cDCE } & \text { PCE } & \text { tDCE } & \text { TCE } & \text { VC } & \text { Chloride } & \text { Nitrate } & \text { Nitrite } & \text { Sulfate } \\ \text { SRS 352 } & 0 & 0 & 2920 & 0 & 0 & 0 & 72 & 0 & 0 & 0 \\ \text { SRS 359 } & 0 & 0 & 2560 & 0 & 0 & 0 & 72 & 0 & 0 & 0 \\ \text { SRS 385 } & 0 & 0 & 2520 & 0 & 0 & 0 & 72 & 0 & 0 & 0 \\ \text { SRS 358 } & 0 & 0 & 2400 & 0 & 0 & 0 & 50 & 5 & 0 & 15 \\ \text { SRS 371 } & 0 & 0 & 2400 & 0 & 0 & 0 & 44 & 0 & 0 & 15 \\ \text { SRS 373 } & 0 & 0 & 2480 & 0 & 0 & 0 & 48 & 0 & 0 & 15 \\ \text { SRS 362 } & 0 & 0 & 2320 & 0 & 0 & 0 & 49 & 5.5 & 3.1 & 15 \\ \text { SRS 370 } & 0 & 0 & 2160 & 0 & 0 & 0 & 55 & 5.4 & 3.2 & 16 \\ \text { SRS 393 } & 0 & 0 & 1840 & 0 & 0 & 0 & 51 & 4.9 & 0 & 15 \\ \text { SRS 350 } & 0 & 0 & 1840 & 0 & 44 & 0 & 36 & 0 & 0 & 0 \\ \text { SRS 354 } & 0 & 0 & 1840 & 0 & 44 & 0 & 34 & 1 & 0 & 0 \\ \text { SRS 375 } & 0 & 0 & 1680 & 0 & 40 & 0 & 35 & 1 & 0 & 0 \\ \text { SRS 363 } & 0 & 0 & 1760 & 0 & 12 & 0 & 34 & 0 & 0 & 0 \\ \text { SRS 387 } & 0 & 0 & 1920 & 0 & 12 & 0 & 31 & 0 & 0 & 0 \\ \text { SRS 392 } & 0 & 0 & 2000 & 0 & 12 & 0 & 31 & 0 & 0 & 0 \\ \text { SRS 351 } & 0 & 0 & 1720 & 0 & 0 & 0 & 49 & 0 & 0 & 14 \\ \text { SRS 379 } & 0 & 0 & 2040 & 0 & 0 & 0 & 33 & 0 & 0 & 14 \\ \text { SRS 388 } & 0 & 0 & 1880 & 0 & 12 & 0 & 33 & 0 & 0 & 14 \\ \text { SRS 361 } & 0 & 0 & 2280 & 0 & 0 & 0 & 61 & 5.2 & 4.2 & 15 \\ \text { SRS 372 } & 0 & 0 & 2440 & 0 & 0 & 0 & 96 & 5.5 & 4.1 & 19 \\ \text { SRS 378 } & 0 & 0 & 2320 & 0 & 0 & 0 & 17 & 5.1 & 3 & 15 \\ \text { SRS 369 } & 0 & 0 & 2040 & 0 & 0 & 0 & 50 & 0 & 0 & 0 \\ \text { SRS 390 } & 0 & 0 & 1760 & 0 & 0 & 0 & 54 & 0 & 0 & 0 \\ \text { SRS 394 } & 0 & 0 & 1680 & 0 & 0 & 0 & 50 & 0 & 0 & 0\end{array}$


WSRC-STI-2006-00189, Rev. 0

Table A.9 General data for treatment $3 \mathrm{Fe}$ microcosms and Ferrous concentrations.

$\begin{array}{lllll}\text { Sample ID } & \text { incubation (days) } & \text { lab project } & \text { Ferrous Iron (mg/l) } & \text { Solids (\%) } \\ \text { SRS 405 } & 2 & \text { P0507166 } & 1 & 36 \\ \text { SRS 411 } & 2 & \text { P0507166 } & 0 & 48 \\ \text { SRS 448 } & 2 & \text { P0507166 } & 0 & 43 \\ \text { SRS 416 } & 7 & \text { P0507294 } & 3.5 & 47 \\ \text { SRS 417 } & 7 & \text { P0507294 } & 3 & 51 \\ \text { SRS 437 } & 7 & \text { P0507294 } & 1.5 & 54 \\ \text { SRS 414 } & 14 & \text { P0507424 } & 1 & 50 \\ \text { SRS 434 } & 14 & \text { P0507424 } & 5 & 51 \\ \text { SRS 442 } & 14 & \text { P0507424 } & 0 & 48 \\ \text { SRS 401 } & 21 & \text { P0508157 } & 1.5 & 57 \\ \text { SRS 402 } & 21 & \text { P0508157 } & 11 & 52 \\ \text { SRS 420 } & 21 & \text { P0508157 } & 3.5 & 47 \\ \text { SRS 424 } & 28 & \text { P0508189 } & 2 & 47 \\ \text { SRS 425 } & 28 & \text { P0508189 } & 1 & 46 \\ \text { SRS 445 } & 28 & \text { P0508189 } & 0 & 51 \\ \text { SRS 406 } & 41 & \text { P0508393 } & 1.5 & 33 \\ \text { SRS 408 } & 41 & \text { P0508393 } & 1.5 & 39 \\ \text { SRS 439 } & 41 & \text { P0508393 } & 2 & 44 \\ \text { SRS 404 } & 54 & \text { P0509094 } & 2.5 & 55 \\ \text { SRS 430 } & 54 & \text { P0509094 } & 3 & 49 \\ \text { SRS 436 } & 54 & \text { P0509094 } & 2 & 51 \\ \text { SRS 415 } & 84 & \text { P0510066 } & 2.5 & 53 \\ \text { SRS 428 } & 84 & \text { P0510066 } & 1 & 52 \\ \text { SRS 443 } & 84 & \text { P0510066 } & 0 & 49\end{array}$


WSRC-STI-2006-00189, Rev. 0

September 19, 2006

Page 53 of 82

Table A.10 Dissolved gas concentrations (ug/l) for Treatment 3Fe microcosms.

$\begin{array}{lllllllll}\text { Sample ID } & \text { Acetylene } & \text { Ethane } & \text { Ethene } & \text { iso-Butane } & \text { Methane } & \text { n-Butane } & \text { Propane } & \text { Propene } \\ \text { SRS 405 } & 0 & 72 & 0.24 & 0 & 19.6 & 0 & 0 & 0 \\ \text { SRS 411 } & 0 & 68 & 0.24 & 0 & 19.2 & 0 & 0 & 0 \\ \text { SRS 448 } & 0 & 72 & 0.24 & 0 & 20 & 0 & 0 & 0 \\ \text { SRS 416 } & 0 & 30.4 & 0.28 & 0 & 16 & 0 & 0 & 0 \\ \text { SRS 417 } & 0 & 33.2 & 0.48 & 0 & 17.2 & 0 & 0 & 0 \\ \text { SRS 437 } & 0 & 25.2 & 0.4 & 0 & 13.6 & 0 & 0 & 0 \\ \text { SRS 414 } & 0 & 31.6 & 0 & 0 & 9.6 & 0 & 0 & 0 \\ \text { SRS 434 } & 0 & 20.4 & 0 & 0 & 8 & 0 & 0 & 0 \\ \text { SRS 442 } & 0 & 22 & 0 & 0 & 7.2 & 0 & 0 & 0 \\ \text { SRS 401 } & 0 & 11.6 & 0.48 & 0 & 8 & 0 & 0 & 0 \\ \text { SRS 402 } & 0 & 12.8 & 0.44 & 0 & 6.8 & 0 & 0 & 0 \\ \text { SRS 420 } & 0 & 14 & 0.36 & 0 & 7.6 & 0 & 0 & 0 \\ \text { SRS 424 } & 0 & 26.8 & 1.08 & 0 & 30.8 & 0 & 0 & 0 \\ \text { SRS 425 } & 0 & 28 & 0.88 & 0 & 24 & 0 & 0 & 0 \\ \text { SRS 445 } & 0 & 27.6 & 0.72 & 0 & 20 & 0 & 0 & 0 \\ \text { SRS 406 } & 0 & 39.6 & 2.88 & 0 & 17.2 & 0 & 0 & 0 \\ \text { SRS 408 } & 0 & 44 & 2.48 & 0 & 15.6 & 0 & 0 & 0 \\ \text { SRS 439 } & 0 & 52 & 2.72 & 0 & 17.2 & 0 & 0 & 0 \\ \text { SRS 404 } & 0 & 16.4 & 1.48 & 0 & 22 & 0 & 0 & 0 \\ \text { SRS 430 } & 0 & 17.2 & 1.92 & 0 & 28 & 0 & 0 & 0 \\ \text { SRS 436 } & 0 & 18.8 & 1 & 0 & 18 & 0 & 0.4 & 0 \\ \text { SRS 415 } & 0 & 7.2 & 2.16 & 0 & 10.8 & 0.76 & 0.68 & 0 \\ \text { SRS 428 } & 0 & 5.6 & 1.92 & 0 & 10 & 0 & 0.4 & 0 \\ \text { SRS 443 } & 0 & 6 & 1.76 & 0 & 9.6 & 0 & 0.44 & 0\end{array}$


WSRC-STI-2006-00189, Rev. 0

Table A.11 Chlorinated ethene (ug/l) and common ion (mg/l) concentrations for Treatment $3 \mathrm{Fe}$ microcosms.

$\begin{array}{lllllllllll}\text { Sample ID } & 11 D C E & \text { cDCE } & \text { PCE } & \text { tDCE } & \text { TCE } & \text { VC } & \text { Chloride } & \text { Nitrate } & \text { Nitrite } & \text { Sulfate } \\ \text { SRS 405 } & 0 & 0 & 1240 & 0 & 0 & 0 & 30 & 5.3 & 3.7 & 16 \\ \text { SRS 411 } & 0 & 0 & 1040 & 0 & 0 & 0 & 60 & 0 & 0 & 0 \\ \text { SRS 448 } & 0 & 0 & 1000 & 0 & 0 & 0 & 30 & 0 & 0 & 15 \\ \text { SRS 416 } & 0 & 0 & 1360 & 0 & 0 & 0 & 27 & 4.9 & 0 & 15 \\ \text { SRS 417 } & 0 & 0 & 1280 & 0 & 0 & 0 & 25 & 0 & 0 & 15 \\ \text { SRS 437 } & 0 & 0 & 1400 & 0 & 0 & 0 & 30 & 0 & 0 & 0 \\ \text { SRS 414 } & 0 & 0 & 1120 & 0 & 0 & 0 & 29 & 5.7 & 3.1 & 15 \\ \text { SRS 434 } & 0 & 0 & 1080 & 0 & 0 & 0 & 28 & 5.4 & 3.2 & 15 \\ \text { SRS 442 } & 0 & 0 & 1040 & 0 & 0 & 0 & 28 & 5.3 & 3.6 & 15 \\ \text { SRS 401 } & 0 & 0 & 920 & 0 & 36 & 0 & 10 & 0 & 0 & 0 \\ \text { SRS 402 } & 0 & 0 & 920 & 0 & 32 & 0 & 12 & 0 & 0 & 0 \\ \text { SRS 420 } & 0 & 0 & 800 & 0 & 32 & 0 & 13 & 0 & 0 & 0 \\ \text { SRS 424 } & 0 & 0 & 920 & 0 & 0 & 0 & 12 & 0 & 0 & 0 \\ \text { SRS 425 } & 0 & 0 & 1040 & 0 & 12 & 0 & 11 & 0 & 0 & 0 \\ \text { SRS 445 } & 0 & 0 & 1000 & 0 & 0 & 0 & 10 & 0 & 0 & 0 \\ \text { SRS 406 } & 0 & 0 & 960 & 0 & 0 & 0 & 25 & 9.7 & 5.2 & 15 \\ \text { SRS 408 } & 0 & 0 & 880 & 0 & 0 & 0 & 20 & 0 & 0 & 14 \\ \text { SRS 439 } & 0 & 0 & 1000 & 0 & 0 & 0 & 23 & 0 & 0 & 14 \\ \text { SRS 404 } & 0 & 0 & 1200 & 0 & 0 & 0 & 33 & 5 & 3.3 & 16 \\ \text { SRS 430 } & 0 & 0 & 680 & 0 & 0 & 0 & 28 & 5.1 & 4.3 & 16 \\ \text { SRS 436 } & 0 & 0 & 1280 & 0 & 0 & 0 & 30 & 5.1 & 4.4 & 16 \\ \text { SRS 415 } & 0 & 0 & 920 & 0 & 0 & 0 & 39 & 9.4 & 0 & 0 \\ \text { SRS 428 } & 0 & 0 & 1000 & 0 & 0 & 0 & 38 & 0 & 0 & 0 \\ \text { SRS 443 } & 0 & 0 & 800 & 0 & 0 & 0 & 36 & 0 & 0 & 29\end{array}$


WSRC-STI-2006-00189, Rev. 0

Table A.12 General data for treatment $4 \mathrm{Fe}$ microcosms and Ferrous concentrations.

$\begin{array}{lllll}\text { Sample ID } & \text { incubation (days) } & \text { lab project } & \text { Ferrous Iron }(\mathrm{mg} / \mathrm{l}) & \text { Solids (\%) } \\ \text { SRS 462 } & 2 & \text { P0507166 } & 3 & 48 \\ \text { SRS 467 } & 2 & \text { P0507166 } & 9.5 & 56 \\ \text { SRS 496 } & 2 & \text { P0507166 } & 6 & 49 \\ \text { SRS 450 } & 7 & \text { P0507294 } & 1.5 & 50 \\ \text { SRS 455 } & 7 & \text { P0507294 } & 4 & 51 \\ \text { SRS 463 } & 7 & \text { P0507294 } & 7.5 & 51 \\ \text { SRS 468 } & 14 & \text { P0507424 } & 1.5 & 47 \\ \text { SRS 472 } & 14 & \text { P0507424 } & 0 & 39 \\ \text { SRS 476 } & 14 & \text { P0507424 } & 6 & 54 \\ \text { SRS 465 } & 21 & \text { P0508157 } & 0 & 47 \\ \text { SRS 495 } & 21 & \text { P0508157 } & 0 & 47 \\ \text { SRS 497 } & 21 & \text { P0508157 } & 22 & 46 \\ \text { SRS 453 } & 28 & \text { P0508189 } & 2 & 56 \\ \text { SRS 493 } & 28 & \text { P0508189 } & 0 & 44 \\ \text { SRS 499 } & 28 & \text { P0508189 } & 0 & 50 \\ \text { SRS 460 } & 41 & \text { P0508393 } & 4 & 41 \\ \text { SRS 470 } & 41 & \text { P0508393 } & 16 & 41 \\ \text { SRS 479 } & 41 & \text { P0508393 } & 5 & 51 \\ \text { SRS 459 } & 54 & \text { P0509094 } & 11 & 48 \\ \text { SRS 461 } & 54 & \text { P0509094 } & 0 & 46 \\ \text { SRS 486 } & 54 & \text { P0509094 } & 0 & 51 \\ \text { SRS 456 } & 84 & \text { P0510066 } & 10 & 48 \\ \text { SRS 457 } & 84 & \text { P0510066 } & 0 & 48 \\ \text { SRS 474 } & 84 & \text { P0510066 } & 2 & 51\end{array}$


WSRC-STI-2006-00189, Rev. 0

September 19, 2006

Page 56 of 82

Table A.13 Dissolved gas concentrations (ug/l) for Treatment 4Fe microcosms.

$\begin{array}{lllllllll}\text { Sample ID } & \text { Acetylene } & \text { Ethane } & \text { Ethene } & \text { iso-Butane } & \text { Methane } & \text { n-Butane } & \text { Propane } & \text { Propene } \\ \text { SRS 462 } & 0 & 84 & 0 & 0 & 19.6 & 0 & 0 & 0 \\ \text { SRS 467 } & 0 & 80 & 0.32 & 0 & 18.8 & 0 & 0 & 0 \\ \text { SRS 496 } & 0 & 76 & 0.32 & 0 & 19.6 & 0 & 0 & 0 \\ \text { SRS 450 } & 0 & 17.2 & 0.52 & 0 & 12 & 0 & 0 & 0 \\ \text { SRS 455 } & 0 & 27.2 & 0 & 0 & 15.2 & 0 & 0 & 0 \\ \text { SRS 463 } & 0 & 30 & 0 & 0 & 15.6 & 0 & 0 & 0 \\ \text { SRS 468 } & 0 & 26.4 & 0 & 0 & 7.6 & 0 & 0 & 0 \\ \text { SRS 472 } & 0 & 26.8 & 0.28 & 0 & 8 & 0 & 0 & 0 \\ \text { SRS 476 } & 0 & 27.2 & 0 & 0 & 8.4 & 0 & 0 & 0 \\ \text { SRS 465 } & 0 & 73.6 & 0.8 & 0 & 19.2 & 0 & 0 & 0 \\ \text { SRS 495 } & 0 & 77.6 & 0.8 & 0 & 20 & 0 & 0 & 0 \\ \text { SRS 497 } & 0 & 80 & 0.8 & 0 & 22.4 & 0 & 0 & 0 \\ \text { SRS 453 } & 0 & 26 & 0.84 & 0 & 20 & 0 & 0 & 0 \\ \text { SRS 493 } & 0 & 50.4 & 1.36 & 0 & 36 & 0 & 0 & 0 \\ \text { SRS 499 } & 0 & 28.4 & 0.64 & 0 & 17.6 & 0 & 0 & 0 \\ \text { SRS 460 } & 0 & 96 & 4.8 & 0 & 26.4 & 0 & 0 & 0 \\ \text { SRS 470 } & 0 & 96 & 4.4 & 0 & 25.6 & 0 & 0 & 0 \\ \text { SRS 479 } & 0 & 96 & 4.08 & 0 & 24 & 0 & 0 & 0 \\ \text { SRS 459 } & 0 & 32.8 & 2 & 0 & 32 & 0 & 0 & 0 \\ \text { SRS 461 } & 0 & 17.6 & 1.12 & 0 & 15.2 & 0 & 0.4 & 0 \\ \text { SRS 486 } & 0 & 35.2 & 1.84 & 0 & 28.8 & 0 & 0 & 0 \\ \text { SRS 456 } & 0 & 10.4 & 3.2 & 0 & 15.2 & 0 & 0 & 0 \\ \text { SRS 457 } & 0 & 10 & 2.16 & 0 & 7.6 & 0 & 0 & 0 \\ \text { SRS 474 } & 0 & 9.6 & 1.72 & 0 & 8.8 & 0 & 0.48 & 0\end{array}$


WSRC-STI-2006-00189, Rev. 0

September 19, 2006

Page 57 of 82

Table A.14 Chlorinated ethene (ug/l) and common ion (mg/l) concentrations for Treatment $4 \mathrm{Fe}$ microcosms.

$\begin{array}{lllllllllll}\text { Sample ID } & 11 D C E & \text { cDCE } & \text { PCE } & \text { tDCE } & \text { TCE } & \text { VC } & \text { Chloride } & \text { Nitrate } & \text { Nitrite } & \text { Sulfate } \\ \text { SRS 462 } & 0 & 0 & 520 & 0 & 0 & 0 & 0 & 0 & 0 & 0 \\ \text { SRS 467 } & 0 & 0 & 480 & 0 & 0 & 0 & 0 & 11 & 8.1 & 31 \\ \text { SRS 496 } & 0 & 0 & 440 & 0 & 0 & 0 & 35 & 0 & 0 & 0 \\ \text { SRS 450 } & 0 & 0 & 440 & 0 & 0 & 0 & 19 & 5.7 & 4.1 & 15 \\ \text { SRS 455 } & 0 & 0 & 480 & 0 & 0 & 0 & 18 & 5.4 & 4.1 & 15 \\ \text { SRS 463 } & 0 & 0 & 384 & 0 & 0 & 0 & 19 & 5.5 & 4.1 & 15 \\ \text { SRS 468 } & 0 & 0 & 328 & 0 & 0 & 0 & 18 & 5.7 & 4.2 & 15 \\ \text { SRS 472 } & 0 & 0 & 440 & 0 & 0 & 0 & 18 & 5.4 & 3.7 & 15 \\ \text { SRS 476 } & 0 & 0 & 384 & 0 & 0 & 0 & 18 & 5.4 & 3.8 & 15 \\ \text { SRS 465 } & 0 & 0 & 360 & 0 & 12 & 0 & 3.4 & 1.2 & 0 & 0 \\ \text { SRS 495 } & 0 & 0 & 340 & 0 & 0 & 0 & 3 & 1.2 & 0 & 0.9 \\ \text { SRS 497 } & 0 & 0 & 352 & 0 & 0 & 0 & 5.3 & 1.5 & 0 & 1.4 \\ \text { SRS 453 } & 0 & 0 & 2320 & 0 & 16 & 0 & 3.4 & 2 & 0 & 6.9 \\ \text { SRS 493 } & 0 & 0 & 400 & 0 & 0 & 0 & 1.5 & 1.6 & 2.7 & 3.9 \\ \text { SRS 499 } & 0 & 0 & 2240 & 0 & 0 & 0 & 2.5 & 1.7 & 2.9 & 0 \\ \text { SRS 460 } & 0 & 0 & 2320 & 0 & 0 & 0 & 18 & 0 & 0 & 14 \\ \text { SRS 470 } & 0 & 0 & 1880 & 0 & 0 & 0 & 17 & 0 & 0 & 14 \\ \text { SRS 479 } & 0 & 0 & 2160 & 0 & 0 & 0 & 17 & 0 & 0 & 0 \\ \text { SRS 459 } & 0 & 0 & 2240 & 0 & 0 & 0 & 20 & 6.8 & 5.4 & 17 \\ \text { SRS 461 } & 36 & 400 & 3600 & 0 & 208 & 0 & 19 & 6.3 & 4.8 & 16 \\ \text { SRS 486 } & 20 & 136 & 3080 & 0 & 72 & 0 & 20 & 5.8 & 4.6 & 16 \\ \text { SRS 456 } & 0 & 0 & 2000 & 0 & 0 & 0 & 30 & 0 & 0 & 29 \\ \text { SRS 457 } & 0 & 0 & 2240 & 0 & 0 & 0 & 31 & 0 & 0 & 29 \\ \text { SRS 474 } & 0 & 0 & 1760 & 0 & 0 & 0 & 30 & 9.4 & 0 & 29\end{array}$


WSRC-STI-2006-00189, Rev. 0

Table A.15 General data for treatment $5 \mathrm{Fe}$ microcosms and Ferrous concentrations.

$\begin{array}{llll}\text { Sample ID } & \text { incubation (days) } & \text { lab project } & \text { Ferrous Iron }(\mathrm{mg} / \mathrm{l}) \\ \text { SRS 513 } & 2 & \mathrm{P} 0507166 & 0 \\ \text { SRS 530 } & 2 & \mathrm{P} 0507166 & 0 \\ \text { SRS 534 } & 2 & \mathrm{P} 0507166 & 0 \\ \text { SRS 509 } & 7 & \mathrm{P} 0507294 & 0 \\ \text { SRS 523 } & 7 & \mathrm{P} 0507294 & 0 \\ \text { SRS 533 } & 7 & \mathrm{P} 0507294 & 0 \\ \text { SRS 512 } & 14 & \mathrm{P} 0507424 & 0 \\ \text { SRS 520 } & 14 & \mathrm{P} 0507424 & 0 \\ \text { SRS 522 } & 14 & \mathrm{P} 0507424 & 0 \\ \text { SRS 504 } & 21 & \mathrm{P} 0508157 & 0 \\ \text { SRS 508 } & 21 & \mathrm{P} 0508157 & 0 \\ \text { SRS 510 } & 21 & \mathrm{P} 0508157 & 0 \\ \text { SRS 502 } & 28 & \mathrm{P} 0508189 & 0 \\ \text { SRS 503 } & 28 & \mathrm{P} 0508189 & 0 \\ \text { SRS 507 } & 28 & \mathrm{P} 0508189 & 0 \\ \text { SRS 526 } & 41 & \mathrm{P} 0508393 & 0 \\ \text { SRS 531 } & 41 & \mathrm{P} 0508393 & 0 \\ \text { SRS 537 } & 41 & \mathrm{P} 0508393 & 0 \\ \text { SRS 500 } & 54 & \mathrm{P} 0509094 & 0 \\ \text { SRS 501 } & 54 & \mathrm{P} 0509094 & 0 \\ \text { SRS 506 } & 54 & \mathrm{P} 0509094 & 0 \\ \text { SRS 515 } & 84 & \mathrm{P} 0510066 & 0 \\ \text { SRS 521 } & 84 & \mathrm{P} 0510066 & 0 \\ \text { SRS 529 } & 84 & \mathrm{P} 0510066 & 0\end{array}$


WSRC-STI-2006-00189, Rev. 0

September 19, 2006

Page 59 of 82

Table A.16 Dissolved gas concentrations (ug/l) for Treatment 5Fe microcosms.

$\begin{array}{lllllllll}\text { Sample ID } & \text { Acetylene } & \text { Ethane } & \text { Ethene } & \text { iso-Butane } & \text { Methane } & \text { n-Butane } & \text { Propane } & \text { Propene } \\ \text { SRS 513 } & 0 & 76 & 0 & 0 & 15.6 & 0 & 0 & 0 \\ \text { SRS 530 } & 0 & 84 & 0 & 0 & 17.2 & 0 & 0 & 0 \\ \text { SRS 534 } & 0 & 84 & 0 & 0 & 17.6 & 0 & 0 & 0 \\ \text { SRS 509 } & 0 & 33.2 & 4.4 & 0 & 18.4 & 0 & 0 & 0 \\ \text { SRS 523 } & 0 & 34.4 & 1.52 & 0 & 15.2 & 0 & 0 & 0 \\ \text { SRS 533 } & 0 & 36.8 & 5.6 & 0 & 20 & 0 & 0 & 0 \\ \text { SRS 512 } & 0 & 29.6 & 0 & 0 & 7.6 & 0 & 0 & 0 \\ \text { SRS 520 } & 0 & 30.8 & 0 & 0 & 8.4 & 0 & 0 & 0 \\ \text { SRS 522 } & 0 & 36.8 & 0 & 0 & 9.2 & 0 & 0 & 0 \\ \text { SRS 504 } & 0 & 36.4 & 0.4 & 0 & 9.6 & 0 & 0 & 0 \\ \text { SRS 508 } & 0 & 48 & 0.44 & 0 & 11.2 & 0 & 0 & 0 \\ \text { SRS 510 } & 0 & 44 & 0.44 & 0 & 10.8 & 0 & 0 & 0 \\ \text { SRS 502 } & 0 & 40 & 0.72 & 0 & 20 & 0 & 0 & 0 \\ \text { SRS 503 } & 0 & 12.4 & 0.6 & 0 & 18 & 0 & 0 & 0 \\ \text { SRS 507 } & 0 & 16 & 0.72 & 0 & 18.4 & 0 & 0 & 0 \\ \text { SRS 526 } & 0 & 48 & 1.84 & 0 & 11.2 & 0 & 0 & 0 \\ \text { SRS 531 } & 0 & 52 & 1.92 & 0 & 11.2 & 0 & 0 & 0 \\ \text { SRS 537 } & 0 & 52 & 1.92 & 0 & 11.2 & 0 & 0 & 0 \\ \text { SRS 500 } & 0 & 28 & 1 & 0 & 14.4 & 0 & 0 & 0 \\ \text { SRS 501 } & 0 & 29.2 & 0.96 & 0 & 14.4 & 0 & 0 & 0 \\ \text { SRS 506 } & 0 & 37.6 & 0.88 & 0 & 13.6 & 0 & 0 & 0 \\ \text { SRS 515 } & 0 & 12 & 1.88 & 0 & 6.8 & 0 & 0 & 0 \\ \text { SRS 521 } & 0 & 37.2 & 1.48 & 0 & 7.6 & 0 & 0 & 0 \\ \text { SRS 529 } & 0 & 29.6 & 1.08 & 0 & 8 & 0 & 0 & 0\end{array}$


WSRC-STI-2006-00189, Rev. 0

September 19, 2006

Page 60 of 82

Table A.17 Chlorinated ethene (ug/l)and common ion concentrations (mg/l) for Treatment 5Fe microcosms.

\begin{tabular}{|c|c|c|c|c|c|c|c|c|c|c|}
\hline Sample ID & 11DCE & cDCE & PCE & $\mathrm{tDCE}$ & TCE & $\mathrm{VC}$ & Chloride & Nitrate & Nitrite & Sulfate \\
\hline SRS 513 & 0 & 10400 & 8800 & 280 & 10800 & 0 & 0 & 0 & 0 & 0 \\
\hline SRS 530 & 0 & 10400 & 8800 & 312 & 10400 & 0 & 0 & 0 & 0 & 2.9 \\
\hline SRS 534 & 0 & 8800 & 8000 & 384 & 9600 & 0 & 0 & 0 & 0 & 2.9 \\
\hline SRS 509 & 0 & 12400 & 10000 & 560 & 11600 & 0 & 0 & 0 & 0 & 0 \\
\hline SRS 523 & 0 & 12000 & 9600 & 368 & 11200 & 0 & 0 & 0 & 0 & 0 \\
\hline SRS 533 & 0 & 10800 & 8400 & 440 & 10000 & 0 & 0 & 0 & 0 & 0 \\
\hline SRS 512 & 0 & 11200 & 8000 & 1160 & 10000 & 0 & 0 & 0 & 0 & 0 \\
\hline SRS 520 & 0 & 9600 & 7600 & 1080 & 9600 & 0 & 0 & 0 & 0 & 0 \\
\hline SRS 522 & 0 & 9600 & 8000 & 1280 & 9200 & 0 & 0 & 0 & 0 & 15 \\
\hline SRS 504 & 0 & 9200 & 5600 & 400 & 7600 & 0 & 0 & 0 & 0 & 0 \\
\hline SRS 508 & 0 & 9200 & 6000 & 232 & 7600 & 0 & 0 & 0 & 0 & 0 \\
\hline SRS 510 & 0 & 9600 & 6400 & 320 & 8000 & 0 & 0 & 0 & 0 & 0 \\
\hline SRS 502 & 0 & 11600 & 7200 & 276 & 8800 & 0 & 0 & 0 & 0 & 0 \\
\hline SRS 503 & 0 & 12400 & 8000 & 332 & 8400 & 0 & 0 & 0 & 0 & 0 \\
\hline SRS 507 & 0 & 11600 & 8000 & 308 & 8400 & 0 & 0 & 0 & 0 & 0 \\
\hline SRS 526 & 0 & 10800 & 7200 & 480 & 9200 & 0 & 1.7 & 0 & 0 & 1.4 \\
\hline SRS 531 & 0 & 8400 & 5600 & 440 & 7600 & 0 & 1.6 & 0 & 0 & 1.4 \\
\hline SRS 537 & 0 & 8400 & 5200 & 344 & 7600 & 0 & 1.6 & 0 & 0 & 1.4 \\
\hline SRS 500 & 0 & 12000 & 8400 & 308 & 10400 & 0 & 3.5 & 0 & 0 & 3.1 \\
\hline SRS 501 & 0 & 11600 & 7600 & 340 & 10800 & 0 & 3.5 & 0 & 0 & 3.2 \\
\hline SRS 506 & 0 & 10800 & 7200 & 312 & 10800 & 0 & 3.5 & 0 & 0 & 3.1 \\
\hline SRS 515 & 0 & 12400 & 5200 & 368 & 8000 & 0 & 3.2 & 0 & 0 & 0 \\
\hline SRS 521 & 0 & 12000 & 5600 & 332 & 8400 & 0 & 2.9 & 0 & 0 & 3 \\
\hline SRS 529 & 0 & 12800 & 7200 & 392 & 9600 & 0 & 2.9 & 0 & 0 & 2.9 \\
\hline
\end{tabular}


WSRC-STI-2006-00189, Rev. 0

Table A.18 General data for treatment 1ES microcosms and Ferrous Iron concentrations.

$\begin{array}{lllll}\text { Sample ID } & \text { incubation (days) } & \text { lab project } & \text { Ferrous Iron }(\mathrm{mg} / \mathrm{l}) & \text { Solids }(\%) \\ \text { EOS 1-1 } & 0 & \text { P0505024 } & 4 & 32 \\ \text { EOS 3-1 } & 0 & \text { P0505024 } & 0 & 40 \\ \text { EOS 4-1 } & 0 & \text { P0505024 } & 0 & 33 \\ \text { EOS 36-1 } & 32 & \text { P0505433 } & 28 & 42 \\ \text { EOS 39-1 } & 32 & \text { P0505433 } & 20 & 48 \\ \text { EOS 40-1 } & 32 & \text { P0505433 } & 116 & 43 \\ \text { EOS 14-1 } & 60 & \text { P0506417 } & & 46 \\ \text { EOS 6-1 } & 60 & \text { P0506417 } & & 29 \\ \text { EOS 8-1 } & 60 & \text { P0506417 } & & 48 \\ \text { EOS 20-1 } & 95 & \text { P0508021 } & 26.5 & 49 \\ \text { EOS 45-1 } & 95 & \text { P0508021 } & 40.5 & 49 \\ \text { EOS 5-1 } & 95 & \text { P0508021 } & 13 & 42 \\ \text { EOS 12-1 } & 125 & \text { P0509028 } & 38 & 53 \\ \text { EOS 17-1 } & 125 & \text { P0509028 } & 68 & 46 \\ \text { EOS 2-1 } & 125 & \text { P0509028 } & 76 & 48 \\ \text { EOS 26-1 } & 158 & \text { P0510066 } & 47 & 57 \\ \text { EOS 44-1 } & 158 & \text { P0510066 } & 37 & 32 \\ \text { EOS 7-1 } & 158 & \text { P0510066 } & 49 & 63 \\ \text { EOS 13-1 } & 200 & \text { P0511158 } & 45 & 63 \\ \text { EOS 29-1 } & 200 & \text { P0511158 } & 19 & \end{array}$


WSRC-STI-2006-00189, Rev. 0

September 19, 2006

Page 62 of 82

Table A.19 Dissolved gas concentrations (ug/l) for Treatment 1ES microcosms.

$\begin{array}{llllllll}\text { Sample ID } & \begin{array}{l}\text { incubation } \\ \text { (days) }\end{array} & \text { Acetylene } & \text { Ethane } & \text { Ethene } & \text { iso-Butane } & \text { Methane } & \text { n-Butat } \\ \text { EOS 1-1 } & 0 & 0 & 6.4 & 2.6 & 2.88 & 76 & 8.4 \\ \text { EOS 3-1 } & 0 & 0 & 6.4 & 1.2 & 0 & 56 & 1.32 \\ \text { EOS 4-1 } & 0 & 0 & 6.4 & 1.04 & 0 & 56 & 0 \\ \text { EOS 36-1 } & 32 & 0 & 1.76 & 1.2 & 0 & 304 & 0 \\ \text { EOS 39-1 } & 32 & 0 & 3.24 & 0.84 & 0 & 140 & 0 \\ \text { EOS 40-1 } & 32 & 0 & 3.16 & 0.88 & 0 & 112 & 0 \\ \text { EOS 14-1 } & 60 & 0 & 48 & 0.6 & 0 & 48 & 0 \\ \text { EOS 6-1 } & 60 & 0 & 48 & 0.6 & 0 & 52 & 0 \\ \text { EOS 8-1 } & 60 & 0 & 48 & 0.64 & 0 & 52 & 0 \\ \text { EOS 20-1 } & 95 & 0 & 36.8 & 0.72 & 1.68 & 17.6 & 2.48 \\ \text { EOS 45-1 } & 95 & 0 & 42.4 & 0.64 & 0 & 16.8 & 1.44 \\ \text { EOS 5-1 } & 95 & 0 & 30.4 & 2.24 & 4.08 & 35.2 & 8 \\ \text { EOS 12-1 } & 125 & 0 & 13.6 & 1.2 & 0 & 17.6 & 0 \\ \text { EOS 17-1 } & 125 & 0 & 15.2 & 1.2 & 0 & 15.2 & 0 \\ \text { EOS 2-1 } & 125 & 0 & 9.6 & 1.28 & 0 & 12.8 & 0 \\ \text { EOS 26-1 } & 158 & 0 & 112 & 1.12 & 0 & 19.2 & 0 \\ \text { EOS 44-1 } & 158 & 0 & 96 & 1.12 & 0 & 15.2 & 0 \\ \text { EOS 7-1 } & 158 & 0 & 96 & 0.8 & 0 & 15.2 & 0 \\ \text { EOS 13-1 } & 200 & 0 & 11.2 & 0 & 0 & 4.56 & 0 \\ \text { EOS 29-1 } & 200 & 0 & 23.2 & 0.56 & 0 & 7.2 & 0 \\ \text { EOS 38-1 } & 200 & 0 & 20 & 0.56 & 0 & 6.08 & 0\end{array}$


WSRC-STI-2006-00189, Rev. 0

September 19, 2006

Page 63 of 82

Table A.20 Chlorinated ethene (ug/l)and common ion concentrations (mg/l) for Treatment 1ES microcosms.

$\begin{array}{lllllllllll}\text { Sample ID } & \begin{array}{l}\text { incubation } \\ \text { (days) }\end{array} & \text { cDCE } & \text { PCE } & \text { tDCE } & \text { TCE } & \text { VC } & \text { Chloride } & \text { Nitrate } & \text { Nitrite } & \text { Sulfate } \\ \text { EOS 1-1 } & 0 & 84 & 920 & 0 & 18.4 & 120 & 8.6 & 5.1 & 0 & 87 \\ \text { EOS 3-1 } & 0 & 68 & 1080 & 0 & 0 & 112 & 9.9 & 0 & 0 & 81 \\ \text { EOS 4-1 } & 0 & 52 & 960 & 0 & 0 & 72 & 9 & 0 & 0 & 97 \\ \text { EOS 36-1 } & 32 & 0 & 1440 & 0 & 0 & 0 & 31 & 11 & 7.5 & 90 \\ \text { EOS 39-1 } & 32 & 0 & 1360 & 0 & 0 & 0 & 30 & 11 & 6.5 & 100 \\ \text { EOS 40-1 } & 32 & 0 & 2160 & 0 & 0 & 0 & 30 & 11 & 7.2 & 77 \\ \text { EOS 14-1 } & 60 & 0 & 720 & 0 & 0 & 0 & 31 & 0 & 0 & 82 \\ \text { EOS 6-1 } & 60 & 0 & 80 & 0 & 0 & 0 & 31 & 0 & 0 & 100 \\ \text { EOS 8-1 } & 60 & 0 & 112 & 0 & 0 & 0 & 17 & 0 & 0 & 82 \\ \text { EOS 20-1 } & 95 & 16 & 1080 & 0 & 284 & 0 & 19 & 5.4 & 0 & 52 \\ \text { EOS 45-1 } & 95 & 20 & 1360 & 0 & 208 & 0 & 20 & 5.4 & 0 & 74 \\ \text { EOS 5-1 } & 95 & 52 & 520 & 0 & 480 & 0 & 20 & 5.5 & 0 & 68 \\ \text { EOS 12-1 } & 125 & 0 & 1200 & 0 & 0 & 0 & 32 & 0 & 0 & 100 \\ \text { EOS 17-1 } & 125 & 0 & 408 & 0 & 0 & 0 & 32 & 0 & 0 & 99 \\ \text { EOS 2-1 } & 125 & 0 & 1440 & 0 & 32 & 0 & 32 & 9.7 & 0 & 97 \\ \text { EOS 26-1 } & 158 & 0 & 1120 & 0 & 64 & 0 & 31 & 9.4 & 0 & 51 \\ \text { EOS 44-1 } & 158 & 0 & 1120 & 0 & 48 & 0 & 31 & 0 & 0 & 65 \\ \text { EOS 7-1 } & 158 & 0 & 608 & 0 & 64 & 0 & 46 & 0 & 0 & 58 \\ \text { EOS 13-1 } & 200 & 0 & 352 & 0 & 0 & 0 & 29 & 9.7 & 0 & 41 \\ \text { EOS 29-1 } & 200 & 0 & 1280 & 0 & 0 & 0 & 29 & 9.9 & 0 & 39 \\ \text { EOS 38-1 } & 200 & 0 & 2240 & 0 & 0 & 0 & 30 & 10 & 0 & 39\end{array}$


WSRC-STI-2006-00189, Rev. 0

Table A.21 General data for treatment 2ES microcosms and Ferrous Iron concentrations.

$\begin{array}{lllll}\text { Sample ID } & \text { incubation (days) } & \text { lab project } & \text { Ferrous Iron }(\mathrm{mg} / \mathrm{l}) & \text { Solids }(\%) \\ \text { EOS 46-2 } & 0 & \text { P0505024 } & 0 & 41 \\ \text { EOS 47-2 } & 0 & \text { P0505024 } & 0 & 52 \\ \text { EOS 55-2 } & 0 & \text { P0505024 } & 0 & 40 \\ \text { EOS 48-2 } & 32 & \text { P0505433 } & 89 & 47 \\ \text { EOS 53-2 } & 32 & \text { P0505433 } & 29 & 48 \\ \text { EOS 60-2 } & 32 & \text { P0505433 } & 28 & 55 \\ \text { EOS 49-2 } & 60 & \text { P0506417 } & & 46 \\ \text { EOS 57-2 } & 60 & \text { P0506417 } & & 47 \\ \text { EOS 62-2 } & 60 & \text { P0506417 } & & 43 \\ \text { EOS 73-2 } & 95 & \text { P0508021 } & 13 & \\ \text { EOS 76-2 } & 95 & \text { P0508021 } & 17.5 & \\ \text { EOS 87-2 } & 95 & \text { P0508021 } & 9.5 & 57 \\ \text { EOS 68-2 } & 125 & \text { P0509028 } & 19 & 48 \\ \text { EOS 77-2 } & 125 & \text { P0509028 } & 14 & 56 \\ \text { EOS 82-2 } & 125 & \text { P0509028 } & 30 & 41 \\ \text { EOS 51-2 } & 158 & \text { P0510066 } & 31 & 50 \\ \text { EOS 61-2 } & 158 & \text { P0510066 } & 14 & 62 \\ \text { EOS 83-2 } & 158 & \text { P0510066 } & 10 & 61 \\ \text { EOS 88-2 } & 200 & \text { P0511158 } & 9 & \end{array}$


WSRC-STI-2006-00189, Rev. 0

September 19, 2006

Page 65 of 82

Table A.22 Dissolved gas concentrations (ug/l) for Treatment 2ES microcosms.

$\begin{array}{llllllll}\text { Sample ID } & \text { incubation (days) } & \text { Acetylene } & \text { Ethane } & \text { Ethene } & \text { iso-Butane } & \text { Methane } & \text { n-Butane } \\ \text { EOS 46-2 } & 0 & 0 & 6 & 0.92 & 0 & 56 & 0 \\ \text { EOS 47-2 } & 0 & 0 & 6 & 0.88 & 0 & 52 & 0 \\ \text { EOS 55-2 } & 0 & 0 & 6 & 0.88 & 0 & 56 & 0 \\ \text { EOS 48-2 } & 32 & 0 & 4 & 0.92 & 0 & 80 & 0 \\ \text { EOS 53-2 } & 32 & 0 & 2.6 & 0.68 & 0 & 88 & 0 \\ \text { EOS 60-2 } & 32 & 0 & 4 & 0.6 & 0 & 48 & 0 \\ \text { EOS 49-2 } & 60 & 0 & 48 & 0.24 & 0 & 52 & 0 \\ \text { EOS 57-2 } & 60 & 0 & 52 & 0.28 & 0 & 52 & 0 \\ \text { EOS 62-2 } & 60 & 0 & 48 & 0.28 & 0 & 64 & 0 \\ \text { EOS 73-2 } & 95 & 0 & 44 & 0 & 0 & 20 & 0 \\ \text { EOS 76-2 } & 95 & 0 & 60.8 & 0 & 0 & 19.2 & 0 \\ \text { EOS 87-2 } & 95 & 0 & 26 & 0 & 0 & 10.4 & 0 \\ \text { EOS 68-2 } & 125 & 0 & 15.2 & 0.88 & 0 & 24.8 & 0 \\ \text { EOS 77-2 } & 125 & 0 & 16 & 0.72 & 0 & 176 & 0 \\ \text { EOS 82-2 } & 125 & 0 & 18.4 & 0.88 & 0 & 11.2 & 0 \\ \text { EOS 51-2 } & 158 & 0 & 104 & 0.72 & 0 & 16 & 0 \\ \text { EOS 61-2 } & 158 & 0 & 104 & 0.8 & 0 & 28.8 & 0 \\ \text { EOS 83-2 } & 158 & 0 & 48 & 0.36 & 0 & 44 & 0 \\ \text { EOS 88-2 } & 200 & 0 & 18.4 & 0.64 & 0 & 76 & 0 \\ \text { EOS 89-2 } & 200 & 0 & 22.4 & 0.64 & 0 & 160 & 0 \\ \text { EOS-75-2 } & 200 & 0 & 24.8 & 0 & 0 & 6.96 & 0\end{array}$


WSRC-STI-2006-00189, Rev. 0

September 19, 2006

Page 66 of 82

Table A.23 Chlorinated ethene (ug/l)and common ion concentrations ( $\mathrm{mg} / \mathrm{l})$ for Treatment 2ES microcosms.

$\begin{array}{lllllllllll}\text { Sample ID } & \begin{array}{l}\text { incubation } \\ \text { (days) }\end{array} & \text { cDCE } & \text { PCE } & \text { tDCE } & \text { TCE } & \text { VC } & \text { Chloride } & \text { Nitrate } & \text { Nitrite } & \text { Sulfate } \\ \text { EOS 46-2 } & 0 & 52 & 1640 & 0 & 0 & 30 & 16 & 0 & 0 & 0 \\ \text { EOS 47-2 } & 0 & 36 & 1720 & 0 & 0 & 33.2 & 14 & 0 & 0 & 0 \\ \text { EOS 55-2 } & 0 & 0 & 2160 & 0 & 0 & 0 & 10 & 5.3 & 0 & 4.5 \\ \text { EOS 48-2 } & 32 & 0 & 2000 & 0 & 0 & 0 & 30 & 11 & 7 & 27 \\ \text { EOS 53-2 } & 32 & 0 & 2120 & 0 & 0 & 0 & 30 & 11 & 7 & 27 \\ \text { EOS 60-2 } & 32 & 0 & 2200 & 0 & 0 & 0 & 30 & 11 & 7.6 & 28 \\ \text { EOS 49-2 } & 60 & 0 & 2400 & 0 & 0 & 0 & 18 & 0 & 0 & 14 \\ \text { EOS 57-2 } & 60 & 0 & 2040 & 0 & 0 & 0 & 17 & 0 & 0 & 0 \\ \text { EOS 62-2 } & 60 & 0 & 2027 & 0 & 0 & 0 & 0 & 0 & 0 & 0 \\ \text { EOS 73-2 } & 95 & 16 & 1760 & 0 & 168 & 0 & 19 & 0 & 0 & 15 \\ \text { EOS 76-2 } & 95 & 16 & 2000 & 0 & 144 & 0 & 19 & 0 & 0 & 15 \\ \text { EOS 87-2 } & 95 & 0 & 960 & 0 & 120 & 0 & 19 & 0 & 0 & 15 \\ \text { EOS 68-2 } & 125 & 0 & 2160 & 0 & 0 & 0 & 32 & 9.7 & 0 & 29 \\ \text { EOS 77-2 } & 125 & 0 & 1920 & 0 & 0 & 0 & 32 & 9.6 & 3.9 & 29 \\ \text { EOS 82-2 } & 125 & 0 & 1840 & 0 & 0 & 0 & 33 & 11 & 4 & 30 \\ \text { EOS 51-2 } & 158 & 0 & 1600 & 0 & 64 & 0 & 31 & 0 & 0 & 30 \\ \text { EOS 61-2 } & 158 & 0 & 1440 & 0 & 64 & 0 & 31 & 9.4 & 0 & 29 \\ \text { EOS 83-2 } & 158 & 0 & 1920 & 0 & 56 & 0 & 31 & 9.4 & 0 & 30 \\ \text { EOS 88-2 } & 200 & 0 & 1200 & 0 & 0 & 0 & 29 & 9.7 & 0 & 29 \\ \text { EOS 89-2 } & 200 & 0 & 920 & 0 & 0 & 0 & 28 & 9.5 & 0 & 30 \\ \text { EOS-75-2 } & 200 & 0 & 2320 & 0 & 0 & 0 & 28 & 9.4 & 0 & 29\end{array}$


WSRC-STI-2006-00189, Rev. 0

Table A.24 General data for treatment 3ES microcosms and Ferrous Iron concentrations.

$\begin{array}{lllll}\text { Sample ID } & \text { incubation (days) } & \text { lab project } & \text { Ferrous Iron }(\mathrm{mg} / \mathrm{l}) & \text { Solids }(\%) \\ \text { EOS 106-3 } & 6 & \text { P0505024 } & 21.5 & 38 \\ \text { EOS 107-3 } & 6 & \text { P0505024 } & 12.5 & 37 \\ \text { EOS 124-3 } & 6 & \text { P0505024 } & 3.5 & 30 \\ \text { EOS 105-3 } & 32 & \text { P0505433 } & 5.5 & 46 \\ \text { EOS 129-3 } & 32 & \text { P0505433 } & 9 & 49 \\ \text { EOS 91-3 } & 32 & \text { P0505433 } & 0 & 48 \\ \text { EOS 111-3 } & 60 & \text { P0506417 } & & 53 \\ \text { EOS 116-3 } & 60 & \text { P0506417 } & & 47 \\ \text { EOS 121-3 } & 60 & \text { P0506417 } & & 59 \\ \text { EOS 112-3 } & 95 & \text { P0508021 } & 26 & 46 \\ \text { EOS 132-3 } & 95 & \text { P0508021 } & 26.5 & 51 \\ \text { EOS 134-3 } & 95 & \text { P0508021 } & 47.5 & 56 \\ \text { EOS 109-3 } & 125 & \text { P0509028 } & 77 & 53 \\ \text { EOS 110-3 } & 125 & \text { P0509028 } & 0 & 60 \\ \text { EOS 137-3 } & 125 & \text { P0509028 } & 0 & 49 \\ \text { EOS 104-3 } & 158 & \text { P0510066 } & 22 & 44 \\ \text { EOS 127-3 } & 158 & \text { P0510066 } & 48 & 66 \\ \text { EOS 130-3 } & 158 & \text { P0510066 } & 45 & 53 \\ \text { EOS 117-3 } & 200 & \text { P0511158 } & 27.5 & \end{array}$


WSRC-STI-2006-00189, Rev. 0

Table A.25 Dissolved gas concentrations (ug/l) for Treatment 3ES microcosms.

Sample ID incubation Acetylene Ethane Ethene iso-Butane Methane n-Butane

\begin{tabular}{|c|c|c|c|c|c|c|}
\hline EOS $106-3$ & $\begin{array}{l}\text { (days } \\
6\end{array}$ & 0 & 10 & 0.6 & 0 & 112 \\
\hline EOS 107-3 & 6 & 0 & 9.6 & 0.72 & 0 & 104 \\
\hline EOS 124-3 & 6 & 0 & 12 & 0.76 & 0 & 108 \\
\hline EOS 105-3 & 32 & 0 & 5.2 & 0.4 & 0 & 72 \\
\hline EOS 129-3 & 32 & 0 & 6 & 0.92 & 0 & 84 \\
\hline EOS 91-3 & 32 & 0 & 4.4 & 0.6 & 0 & 52 \\
\hline EOS 111-3 & 60 & 0 & 48 & 0 & 0 & 48 \\
\hline EOS 116-3 & 60 & 0 & 48 & 0 & 0 & 92 \\
\hline EOS 121-3 & 60 & 0 & 48 & 0 & 0 & 68 \\
\hline EOS 112-3 & 95 & 0 & 38.8 & 0.24 & 0 & 8 \\
\hline EOS 132-3 & 95 & 0 & 72.8 & 0 & 0 & 38.4 \\
\hline EOS 134-3 & 95 & 0 & 44 & 0 & 0 & 32.4 \\
\hline EOS 109-3 & 125 & 0 & 24.8 & 0.64 & 0 & 54.4 \\
\hline EOS $110-3$ & 125 & 0 & 16 & 0.88 & 0 & 20 \\
\hline EOS 137-3 & 125 & 0 & 20 & 0.96 & 0 & 36.8 \\
\hline EOS 104-3 & 158 & 0 & 96 & 0.8 & 0 & 80 \\
\hline EOS 127-3 & 158 & 0 & 104 & 0.96 & 0 & 88 \\
\hline EOS 130-3 & 158 & 0 & 104 & 0.64 & 0 & 36 \\
\hline EOS 117-3 & 200 & 0 & 22.4 & 0.48 & 0 & 49.6 \\
\hline EOS 118-3 & 200 & 0 & 20.8 & 0 & 0 & 1040 \\
\hline EOS 139-3 & 200 & 0 & 24.8 & 0 & 0 & 176 \\
\hline
\end{tabular}


WSRC-STI-2006-00189, Rev. 0

September 19, 2006

Page 69 of 82

Table A.26 Chlorinated ethene (ug/l)and common ion concentrations ( $\mathrm{mg} / \mathrm{l})$ for Treatment 3ES microcosms.

$\begin{array}{lllllllllll}\text { Sample ID } & \begin{array}{l}\text { incubation } \\ \text { (days) }\end{array} & \text { cDCE } & \text { PCE } & \text { tDCE } & \text { TCE } & \text { VC } & \text { Chloride } & \text { Nitrate } & \text { Nitrite } & \text { Sulfate } \\ \text { EOS 106-3 } & 6 & 0 & 1120 & 0 & 0 & 0 & 8.6 & 0 & 0 & 16 \\ \text { EOS 107-3 } & 6 & 0 & 1320 & 0 & 0 & 0 & 13 & 0 & 0 & 20 \\ \text { EOS 124-3 } & 6 & 0 & 1320 & 0 & 0 & 0 & 8.9 & 0 & 0 & 17 \\ \text { EOS 105-3 } & 32 & 0 & 1080 & 0 & 0 & 0 & 30 & 10 & 7 & 27 \\ \text { EOS 129-3 } & 32 & 0 & 1040 & 0 & 0 & 0 & 30 & 11 & 7.1 & 27 \\ \text { EOS } 91-3 & 32 & 0 & 1000 & 0 & 0 & 0 & 29 & 11 & 7.7 & 27 \\ \text { EOS 111-3 } & 60 & 0 & 1280 & 0 & 0 & 0 & 0 & 0 & 0 & 0 \\ \text { EOS 116-3 } & 60 & 0 & 1160 & 0 & 0 & 0 & 0 & 0 & 0 & 0 \\ \text { EOS 121-3 } & 60 & 0 & 840 & 0 & 0 & 0 & 0 & 0 & 0 & 13 \\ \text { EOS 112-3 } & 95 & 0 & 1080 & 0 & 108 & 0 & 19 & 0 & 0 & 0 \\ \text { EOS 132-3 } & 95 & 0 & 800 & 0 & 92 & 0 & 19 & 0 & 0 & 15 \\ \text { EOS 134-3 } & 95 & 0 & 1080 & 0 & 52 & 0 & 19 & 0 & 0 & 15 \\ \text { EOS 109-3 } & 125 & 0 & 840 & 0 & 0 & 0 & 32 & 9.6 & 0 & 29 \\ \text { EOS 110-3 } & 125 & 0 & 960 & 0 & 0 & 0 & 31 & 0 & 0 & 29 \\ \text { EOS 137-3 } & 125 & 0 & 800 & 0 & 0 & 0 & 31 & 0 & 0 & 29 \\ \text { EOS 104-3 } & 158 & 0 & 960 & 0 & 32 & 0 & & & & \\ \text { EOS 127-3 } & 158 & 0 & 880 & 0 & 0 & 0 & 30 & 0 & 0 & 29 \\ \text { EOS 130-3 } & 158 & 0 & 880 & 0 & 56 & 0 & 36 & 0 & 0 & 0 \\ \text { EOS 117-3 } & 200 & 0 & 880 & 0 & 0 & 0 & 29 & 9.8 & 0 & 30 \\ \text { EOS 118-3 } & 200 & 0 & 480 & 0 & 0 & 0 & 28 & 0 & 0 & 29 \\ \text { EOS 139-3 } & 200 & 0 & 600 & 0 & 0 & 0 & 29 & 9.6 & 0 & 30\end{array}$


WSRC-STI-2006-00189, Rev. 0

Table A.27 General data for treatment 4ES microcosms and Ferrous Iron concentrations.

$\begin{array}{lllll}\text { Sample ID } & \text { incubation (days) } & \text { lab project } & \text { Ferrous Iron }(\mathrm{mg} / \mathrm{l}) & \text { Solids (\%) } \\ \text { EOS 141-4 } & 6 & \text { P0505024 } & 0 & 39 \\ \text { EOS 142-4 } & 6 & \text { P0505024 } & 0 & 43 \\ \text { EOS 154-4 } & 6 & \text { P0505024 } & 0 & 42 \\ \text { EOS 144-4 } & 32 & \text { P0505433 } & 7 & 46 \\ \text { EOS 163-4 } & 32 & \text { P0505433 } & 12.5 & 51 \\ \text { EOS 168-4 } & 32 & \text { P0505433 } & 11 & 42 \\ \text { EOS 152-4 } & 60 & \text { P0506417 } & & 49 \\ \text { EOS 164-4 } & 60 & \text { P0506417 } & & 47 \\ \text { EOS 167-4 } & 60 & \text { P0506417 } & & 49 \\ \text { EOS 159-4 } & 95 & \text { P0508021 } & 39.5 & 48 \\ \text { EOS 182-4 } & 95 & \text { P0508021 } & 29.5 & 40 \\ \text { EOS 188-4 } & 95 & \text { P0508021 } & 25 & 40 \\ \text { EOS 173-4 } & 125 & \text { P0509028 } & 93 & 51 \\ \text { EOS 180-4 } & 125 & \text { P0509028 } & 200 & 56 \\ \text { EOS 189-4 } & 125 & \text { P0509028 } & 29 & 41 \\ \text { EOS 157-4 } & 158 & \text { P0510066 } & 6 & 49 \\ \text { EOS 181-4 } & 158 & \text { P0510066 } & 33 & 59 \\ \text { EOS 186-4 } & 158 & \text { P0510066 } & 20 & 53 \\ \text { EOS 148-4 } & 200 & \text { P0511158 } & 80 & 63 \\ \text { EOS 176-4 } & 200 & \text { P0511158 } & 120 & 63 \\ \text { EOS 179-4 } & 200 & \text { P0511158 } & 24 & \end{array}$


WSRC-STI-2006-00189, Rev. 0

Table A.28 Dissolved gas concentrations (ug/l) for Treatment 4ES microcosms.

Sample ID incubation Acetylene Ethane Ethene iso-Butane Methane n-Butane (days)

$\begin{array}{llllllll}\text { EOS 141-4 } & 6 & 0 & 12.4 & 0.72 & 0 & 104 & 0 \\ \text { EOS 142-4 } & 6 & 0 & 13.2 & 1.04 & 0 & 104 & 0 \\ \text { EOS 154-4 } & 6 & 0 & 12.4 & 0.92 & 0 & 112 & 0 \\ \text { EOS 144-4 } & 32 & 0 & 8.4 & 0.44 & 0 & 35.6 & 0 \\ \text { EOS 163-4 } & 32 & 0 & 9.2 & 0.64 & 0 & 52 & 0 \\ \text { EOS 168-4 } & 32 & 0 & 9.2 & 0.96 & 0 & 60 & 0 \\ \text { EOS 152-4 } & 60 & 0 & 48 & 0.32 & 0 & 52 & 0 \\ \text { EOS 164-4 } & 60 & 0 & 52 & 0.36 & 0 & 52 & 0 \\ \text { EOS 167-4 } & 60 & 0 & 48 & 0.44 & 0 & 52 & 0 \\ \text { EOS 159-4 } & 95 & 0 & 88 & 0 & 0 & 16 & 0 \\ \text { EOS 182-4 } & 95 & 0 & 36.8 & 0 & 0 & 28 & 0 \\ \text { EOS 188-4 } & 95 & 0 & 37.2 & 0 & 0 & 7.6 & 0 \\ \text { EOS 173-4 } & 125 & 0 & 23.2 & 1.28 & 0 & 12 & 0 \\ \text { EOS 180-4 } & 125 & 0 & 23.2 & 0.88 & 0 & 61.6 & 0 \\ \text { EOS 189-4 } & 125 & 0 & 31.2 & 0.96 & 0 & 9.6 & 0 \\ \text { EOS 157-4 } & 158 & 0 & 48 & 0.36 & 0 & 8 & 0 \\ \text { EOS 181-4 } & 158 & 0 & 104 & 0.64 & 0 & 16 & 0 \\ \text { EOS 186-4 } & 158 & & & & & & \\ \text { EOS 148-4 } & 200 & 0 & 43.2 & 0.56 & 0 & 56 & 0 \\ \text { EOS 176-4 } & 200 & 0 & 32.8 & 0 & 0 & 9.6 & 0 \\ \text { EOS 179-4 } & 200 & 0 & 33.6 & 0 & 0 & 8 & 0\end{array}$


WSRC-STI-2006-00189, Rev. 0

September 19, 2006

Page 72 of 82

Table A.29 Chlorinated ethene (ug/l)and common ion concentrations (mg/l) for Treatment 4ES microcosms.

\begin{tabular}{|c|c|c|c|c|c|c|c|c|c|c|}
\hline Sample ID & $\begin{array}{l}\text { incubation } \\
\text { (days) }\end{array}$ & cDCE & PCE & $\mathrm{tDCE}$ & TCE & $\mathrm{VC}$ & Chloride & Nitrate & Nitrite & Sulfate \\
\hline EOS 141-4 & 6 & 0 & 3320 & 0 & 0 & 0 & 8.4 & 0 & 0 & 18 \\
\hline EOS 142-4 & 6 & 0 & 3360 & 0 & 0 & 0 & 7.8 & 0 & 0 & 14 \\
\hline EOS 154-4 & 6 & 0 & 3120 & 0 & 0 & 0 & 8.3 & 0 & 0 & 16 \\
\hline EOS 144-4 & 32 & 0 & 2600 & 0 & 0 & 0 & 30 & 10 & 7.1 & 28 \\
\hline EOS 163-4 & 32 & 0 & 2640 & 0 & 0 & 0 & 29 & 11 & 7.8 & 27 \\
\hline EOS $168-4$ & 32 & 0 & 2560 & 0 & 0 & 0 & 30 & 10 & 7.2 & 27 \\
\hline EOS $152-4$ & 60 & 0 & 3200 & 0 & 0 & 0 & 0 & 0 & 0 & 0 \\
\hline EOS 164-4 & 60 & 0 & 2360 & 0 & 0 & 0 & 17 & 0 & 0 & 13 \\
\hline EOS 167-4 & 60 & 0 & 2400 & 0 & 0 & 0 & 17 & 0 & 0 & 13 \\
\hline EOS 159-4 & 95 & 0 & 2600 & 0 & 48 & 0 & 19 & 0 & 0 & 16 \\
\hline EOS 182-4 & 95 & 0 & 2080 & 0 & 60 & 0 & 35 & 0 & 0 & 30 \\
\hline EOS $188-4$ & 95 & 0 & 2520 & 0 & 52 & 0 & 35 & 0 & 0 & 30 \\
\hline EOS 173-4 & 125 & 0 & 2000 & 0 & 0 & 0 & 31 & 9.5 & 3.8 & 29 \\
\hline EOS $180-4$ & 125 & 0 & 2040 & 0 & 0 & 0 & 31 & 9.5 & 0 & 29 \\
\hline EOS 189-4 & 125 & 0 & 2560 & 0 & 0 & 0 & 31 & 9.7 & 3.9 & 29 \\
\hline EOS 157-4 & 158 & 0 & 2000 & 0 & 48 & 0 & 31 & 9.7 & 0 & 30 \\
\hline EOS 181-4 & 158 & 0 & 2200 & 0 & 20 & 0 & 31 & 0 & 0 & 29 \\
\hline EOS 186-4 & 158 & 0 & 2440 & 0 & 28 & 0 & 31 & 0 & 0 & 29 \\
\hline EOS $148-4$ & 200 & 0 & 1120 & 0 & 0 & 0 & 28 & 9.6 & 0 & 30 \\
\hline EOS 176-4 & 200 & 0 & 1000 & 0 & 0 & 0 & 28 & 9.4 & 0 & 29 \\
\hline EOS 179-4 & 200 & 0 & 2560 & 0 & 72 & 0 & 28 & 9.6 & 0 & 30 \\
\hline
\end{tabular}


WSRC-STI-2006-00189, Rev. 0

Table A.30 General data for treatment 5ES microcosms and Ferrous Iron concentrations.

$\begin{array}{lllll}\text { Sample ID } & \text { incubation (days) } & \text { lab project } & \text { Ferrous Iron }(\mathrm{mg} / \mathrm{l}) & \text { Solids (\%) } \\ \text { EOS 194-5 } & 6 & \text { P0505024 } & 0 & 36 \\ \text { EOS 233-5 } & 6 & \text { P0505024 } & 0 & 35 \\ \text { EOS 235-5 } & 6 & \text { P0505024 } & 1.5 & \\ \text { EOS 200-5 } & 32 & \text { P0505433 } & 10.5 & 42 \\ \text { EOS 208-5 } & 32 & \text { P0505433 } & 13 & 52 \\ \text { EOS 227-5 } & 32 & \text { P0505433 } & 12 & 48 \\ \text { EOS 209-5 } & 60 & \text { P0506417 } & & 38 \\ \text { EOS 219-5 } & 60 & \text { P0506417 } & & 45 \\ \text { EOS 238-5 } & 60 & \text { P0506417 } & & 42 \\ \text { EOS 203-5 } & 95 & \text { P0508021 } & 19 & 41 \\ \text { EOS 204-5 } & 95 & \text { P0508021 } & 16 & 42 \\ \text { EOS 234-5 } & 95 & \text { P0508021 } & 7 & 47 \\ \text { EOS 211-5 } & 125 & \text { P0509028 } & 22 & 47 \\ \text { EOS 212-5 } & 125 & \text { P0509028 } & 8 & 56 \\ \text { EOS 221-5 } & 125 & \text { P0509028 } & 10 & 59 \\ \text { EOS 214-5 } & 158 & \text { P0510066 } & 8 & 48 \\ \text { EOS 223-5 } & 158 & \text { P0510066 } & 10 & 54 \\ \text { EOS 236-5 } & 158 & \text { P0510066 } & 7 & 74 \\ \text { EOS 196-5 } & 200 & \text { P0511158 } & 8 & 57 \\ \text { EOS 230-5 } & 200 & \text { P0511158 } & 10 & 60 \\ \text { EOS 237-5 } & 200 & \text { P0511158 } & 17 & \end{array}$


WSRC-STI-2006-00189, Rev. 0

September 19, 2006

Page 74 of 82

Table A.31 Dissolved gas concentrations (ug/l) for Treatment 5ES microcosms.

$\begin{array}{llllllll}\text { Sample ID } & \begin{array}{l}\text { incubation } \\ \text { (days) }\end{array} & \text { Acetylene } & \text { Ethane } & \text { Ethene } & \text { iso-Butane } & \text { Methane } & \text { n-Butane } \\ \text { EOS 194-5 } & 6 & 0 & 12 & 0.76 & 0 & 108 & 0 \\ \text { EOS 233-5 } & 6 & 0 & 12.4 & 0.68 & 0 & 108 & 0 \\ \text { EOS 235-5 } & 6 & 0 & 11.2 & 0.4 & 0 & 92 & 0 \\ \text { EOS 200-5 } & 32 & 0 & 10.8 & 1.72 & 6.4 & 92 & 0 \\ \text { EOS 208-5 } & 32 & 0 & 10 & 0.68 & 0 & 40 & 0 \\ \text { EOS 227-5 } & 32 & 0 & 11.6 & 0.64 & 0 & 39.6 & 0 \\ \text { EOS 209-5 } & 60 & 0 & 48 & 0.24 & 0 & 56 & 0 \\ \text { EOS 219-5 } & 60 & 0 & 52 & 0.32 & 0 & 56 & 0 \\ \text { EOS 238-5 } & 60 & 0 & 52 & 0.24 & 0 & 60 & 0 \\ \text { EOS 203-5 } & 95 & 0 & 44 & 0 & 0 & 20 & 0 \\ \text { EOS 204-5 } & 95 & 0 & 48 & 0 & 0 & 19.2 & 0 \\ \text { EOS 234-5 } & 95 & 0 & 96 & 0 & 0 & 15.2 & 0 \\ \text { EOS 211-5 } & 125 & 0 & 96 & 0.88 & 0 & 62.4 & 0 \\ \text { EOS 212-5 } & 125 & 0 & 96 & 0.96 & 0 & 76 & 0 \\ \text { EOS 221-5 } & 125 & 0 & 96 & 0.8 & 0 & 104 & 0 \\ \text { EOS 214-5 } & 158 & & & & & & \\ \text { EOS 223-5 } & 158 & 0 & 36.8 & 0.72 & 0 & 69.6 & 0 \\ \text { EOS 236-5 } & 158 & 0 & 35.2 & 0.72 & 0 & 58.4 & 0 \\ \text { EOS 196-5 } & 200 & 0 & 16.8 & 0 & 0 & 33.2 & 0 \\ \text { EOS 230-5 } & 200 & 0 & 88 & 0 & 0 & 12 & 0 \\ \text { EOS 237-5 } & 200 & 0 & 88 & 0.48 & 0 & 60.8 & 0\end{array}$


WSRC-STI-2006-00189, Rev. 0

September 19, 2006

Page 75 of 82

Table A.32 Chlorinated ethene (ug/l)and common ion concentrations ( $\mathrm{mg} / \mathrm{l})$ for Treatment 5ES microcosms.

$\begin{array}{lllllllllll}\text { Sample ID } & \begin{array}{l}\text { incubation } \\ \text { (days) }\end{array} & \text { cDCE } & \text { PCE } & \text { tDCE } & \text { TCE } & \text { VC } & \text { Chloride } & \text { Nitrate } & \text { Nitrite } & \text { Sulfater } \\ \text { EOS 194-5 } & 6 & 0 & 880 & 0 & 0 & 0 & 16 & 6.2 & 0 & 26 \\ \text { EOS 233-5 } & 6 & 0 & 840 & 0 & 0 & 0 & 13 & 0 & 0 & 14 \\ \text { EOS 235-5 } & 6 & 0 & 720 & 0 & 0 & 0 & & & & \\ \text { EOS 200-5 } & 32 & 0 & 1760 & 0 & 0 & 0 & 30 & 11 & 7.9 & 27 \\ \text { EOS 208-5 } & 32 & 0 & 1840 & 0 & 0 & 0 & 29 & 11 & 6.7 & 27 \\ \text { EOS 227-5 } & 32 & 0 & 2120 & 0 & 0 & 0 & 30 & 11 & 7.1 & 28 \\ \text { EOS 209-5 } & 60 & 0 & 600 & 0 & 0 & 0 & 17 & 0 & 0 & 14 \\ \text { EOS 219-5 } & 60 & 0 & 1120 & 0 & 0 & 0 & 17 & 0 & 0 & 14 \\ \text { EOS 238-5 } & 60 & 0 & 600 & 0 & 0 & 0 & 17 & 0 & 0 & 0 \\ \text { EOS 203-5 } & 95 & 0 & 368 & 0 & 56 & 0 & 34 & 0 & 0 & 0 \\ \text { EOS 204-5 } & 95 & 0 & 1800 & 0 & 56 & 0 & 35 & 0 & 0 & 30 \\ \text { EOS 234-5 } & 95 & 0 & 480 & 0 & 44 & 0 & 35 & 0 & 0 & 31 \\ \text { EOS 211-5 } & 125 & 0 & 1640 & 0 & 0 & 0 & 32 & 9.6 & 0 & 29 \\ \text { EOS 212-5 } & 125 & 0 & 1360 & 0 & 0 & 0 & 32 & 9.8 & 3.8 & 29 \\ \text { EOS 221-5 } & 125 & 0 & 1320 & 0 & 0 & 0 & 32 & 0 & 0 & 29 \\ \text { EOS 214-5 } & 158 & 0 & 1280 & 0 & 24 & 0 & 31 & 0 & 0 & 29 \\ \text { EOS 223-5 } & 158 & 0 & 312 & 0 & 0 & 0 & 39 & 0 & 0 & 31 \\ \text { EOS 236-5 } & 158 & 0 & 400 & 0 & 20 & 0 & 33 & 0 & 0 & 29 \\ \text { EOS 196-5 } & 200 & 0 & 880 & 0 & 24 & 0 & 29 & 9.6 & 0 & 29 \\ \text { EOS 230-5 } & 200 & 0 & 2160 & 0 & 0 & 0 & 28 & 9.7 & 0 & 29 \\ \text { EOS 237-5 } & 200 & 0 & 720 & 0 & 0 & 0 & 28 & 0 & 0 & 29\end{array}$


WSRC-STI-2006-00189, Rev. 0

Table A.33 General data for treatment 6ES microcosms and Ferrous Iron concentrations.

\begin{tabular}{|c|c|c|c|c|}
\hline Sample ID & incubation (days) & lab project & Ferrous Iron $(\mathrm{mg} / \mathrm{l})$ & Solids (\%) \\
\hline EOS $247-6$ & 32 & $\mathrm{P} 0505433$ & 0 & 106 \\
\hline EOS 248-6 & 32 & P0505433 & 0 & 107 \\
\hline EOS 289-6 & 32 & P0505433 & 0 & 108 \\
\hline EOS 251-6 & 60 & P0506417 & 0 & 109 \\
\hline EOS 262-6 & 60 & P0506417 & 0 & 110 \\
\hline EOS 270-6 & 60 & P0506417 & 0 & 111 \\
\hline EOS 258-6 & 95 & P0508021 & & 112 \\
\hline EOS 269-6 & 95 & P0508021 & & 113 \\
\hline EOS 276-6 & 95 & P0508021 & & 114 \\
\hline EOS 255-6 & 125 & P0509028 & 0 & 115 \\
\hline EOS 256-6 & 125 & P0509028 & 0 & 116 \\
\hline EOS 264-6 & 125 & P0509028 & 0 & 117 \\
\hline EOS 244-6 & 158 & P0510066 & 0 & 118 \\
\hline EOS 273-6 & 158 & P0510066 & 0 & 119 \\
\hline EOS 290-6 & 158 & P0510066 & 0 & 120 \\
\hline EOS 265-6 & 200 & P0511158 & 0 & 121 \\
\hline EOS 271-6 & 200 & P0511158 & 0 & 122 \\
\hline EOS 280-6 & 200 & P0511158 & 0 & 123 \\
\hline
\end{tabular}


WSRC-STI-2006-00189, Rev. 0

September 19, 2006

Page 77 of 82

Table A.34 Dissolved gas concentrations (ug/l) for Treatment 6ES microcosms.

Sample ID incubation Acetylene Ethane Ethene iso-Butane

Methane n-Butane

$\begin{array}{llllllll}\text { EOS 247-6 } & 32 & 0 & 16.4 & 0.4 & 0 & 33.2 & 0 \\ \text { EOS 248-6 } & 32 & 0 & 13.2 & 0.48 & 0 & 32 & 0 \\ \text { EOS 289-6 } & 32 & 0 & 12 & 0.32 & 0 & 29.2 & 0 \\ \text { EOS 251-6 } & 60 & 0 & 52 & 0 & 0 & 52 & 0 \\ \text { EOS 262-6 } & 60 & 0 & 52 & 0 & 0 & 52 & 0 \\ \text { EOS 270-6 } & 60 & 0 & 52 & 0.36 & 0 & 52 & 0 \\ \text { EOS 258-6 } & 95 & 0 & 100 & 0 & 0 & 17.6 & 0 \\ \text { EOS 269-6 } & 95 & 0 & 76 & 0 & 0 & 14.8 & 0 \\ \text { EOS 276-6 } & 95 & 0 & 112 & 0 & 0 & 30 & 0 \\ \text { EOS 255-6 } & 125 & 0 & 56 & 0.36 & 0 & 8.4 & 0 \\ \text { EOS 256-6 } & 125 & 0 & 56 & 0.32 & 0 & 8.8 & 0 \\ \text { EOS 264-6 } & 125 & 0 & 56 & 0.28 & 0 & 8 & 0 \\ \text { EOS 244-6 } & 158 & 0 & 10.8 & 0.28 & 0 & 5.6 & 0 \\ \text { EOS 273-6 } & 158 & 0 & 10.4 & 0.36 & 0 & 5.6 & 0 \\ \text { EOS 290-6 } & 158 & 0 & 9.6 & 0.32 & 0 & 5.2 & 0 \\ \text { EOS 265-6 } & 200 & 0 & 44 & 0 & 0 & 6.8 & 0 \\ \text { EOS 271-6 } & 200 & & & & & & \\ \text { EOS 280-6 } & 200 & 0 & 44 & 0 & 0 & 6.4 & 0\end{array}$


WSRC-STI-2006-00189, Rev. 0

September 19, 2006

Page 78 of 82

Table A.35 Chlorinated ethene (ug/l)and common ion concentrations (mg/l) for Treatment 6ES microcosms.

$\begin{array}{lllllllllll}\text { Sample ID } & \begin{array}{l}\text { incubation } \\ \text { (days) }\end{array} & \text { cDCE } & \text { PCE } & \text { tDCE } & \text { TCE } & \text { VC } & \text { Chloride } & \text { Nitrate } & \text { Nitrite } & \text { Sulfate } \\ \text { EOS 247-6 } & 32 & 0 & 2560 & 0 & 0 & 0 & 28 & 0 & 0 & 0 \\ \text { EOS 248-6 } & 32 & 0 & 2600 & 0 & 0 & 0 & 28 & 0 & 0 & 27 \\ \text { EOS 289-6 } & 32 & 0 & 1320 & 0 & 0 & 0 & 28 & 0 & 0 & 0 \\ \text { EOS 251-6 } & 60 & 0 & 3720 & 0 & 0 & 0 & 2.8 & 0 & 0 & 2.7 \\ \text { EOS 262-6 } & 60 & 0 & 3800 & 0 & 0 & 0 & 2.9 & 0 & 0 & 2.7 \\ \text { EOS 270-6 } & 60 & 0 & 3440 & 0 & 0 & 0 & 2.8 & 0 & 0 & 2.7 \\ \text { EOS 258-6 } & 95 & 0 & 3960 & 0 & 44 & 0 & 0 & 0 & 0 & 0 \\ \text { EOS 269-6 } & 95 & 0 & 2600 & 0 & 12 & 0 & 0 & 0 & 0 & 3 \\ \text { EOS 276-6 } & 95 & 0 & 2080 & 0 & 0 & 0 & 0 & 0 & 0 & 3 \\ \text { EOS 255-6 } & 125 & 0 & 1920 & 0 & 0 & 0 & 2.9 & 0 & 0 & 2.9 \\ \text { EOS 256-6 } & 125 & 0 & 3160 & 0 & 0 & 0 & 2.9 & 1 & 0 & 2.9 \\ \text { EOS 264-6 } & 125 & 0 & 2560 & 0 & 0 & 0 & 2.9 & 1 & 0 & 2.9 \\ \text { EOS 244-6 } & 158 & 0 & 1080 & 0 & 0 & 0 & 3 & 0 & 0 & 3 \\ \text { EOS 273-6 } & 158 & 0 & 2880 & 0 & 0 & 0 & 2.9 & 0 & 0 & 2.9 \\ \text { EOS 290-6 } & 158 & 0 & 3280 & 0 & 0 & 0 & 2.9 & 0 & 0 & 0 \\ \text { EOS 265-6 } & 200 & 0 & 2040 & 0 & 0 & 0 & 2.8 & 0 & 0 & 3 \\ \text { EOS 271-6 } & 200 & 0 & 2200 & 0 & 0 & 0 & 2.8 & 0 & 0 & 3 \\ \text { EOS 280-6 } & 200 & 0 & 1520 & 0 & 0 & 0 & 2.9 & 0 & 0 & 3.1\end{array}$


WSRC-STI-2006-00189, Rev. 0

Table A36. Data from the TCE re-spike experiment for treatment 1Fe.

$\begin{array}{cccccc}\text { Sample ID } & \text { Incubation } & \text { cDCE } & \text { TCE } & \text { VC } & \text { acetylene } \\ 314 & 0 & <1 & 8593 & <1 & <0.5 \\ 316 & 0 & <1 & 9071 & <1 & <0.5 \\ 336 & 0 & <1 & 9765 & <1 & <0.5 \\ 306 & 7 & <1 & 7291 & <1 & <0.5 \\ 318 & 7 & <1 & 7465 & <1 & <0.5 \\ 324 & 7 & <1 & 7161 & <1 & <0.5 \\ 300 & 15 & <1 & 6944 & <1 & <0.5 \\ 305 & 15 & <1 & 6510 & <1 & <0.5 \\ 327 & 15 & <1 & 7378 & <1 & <0.5 \\ 313 & 21 & <1 & 7812 & <1 & <0.5 \\ 325 & 21 & <1 & 6944 & <1 & \\ 345 & 21 & <1 & 7812 & <1 & \\ 308 & 28 & <1 & 7378 & <1 & <0.5 \\ 310 & 28 & <1 & 6510 & <1 & <0.5 \\ 339 & 28 & <1 & 6928 & <1 & <0.5 \\ 312 & 35 & <1 & 9093 & <1 & <0.5 \\ 323 & 35 & <1 & 9093 & <1 & <0.5 \\ 349 & 35 & <1 & 9959 & <1 & <0.5\end{array}$


WSRC-STI-2006-00189, Rev. 0

Table A37. Data from the TCE re-spike experiment for treatment $2 \mathrm{Fe}$.

$\begin{array}{crllll}\text { Sample ID } & \text { Incubation } & \text { cDCE } & \text { TCE } & \text { VC } & \text { acetylene } \\ 356 & 0 & <1 & 8767 & <1 & <0.5 \\ 389 & 0 & <1 & 8723 & <1 & <0.5 \\ 395 & 0 & <1 & 10763 & <1 & <0.5 \\ 360 & 7 & <1 & 6597 & <1 & <0.5 \\ 365 & 7 & <1 & 6944 & <1 & <0.5 \\ 384 & 7 & <1 & 6944 & <1 & <0.5 \\ 353 & 15 & <1 & 6944 & <1 & <0.5 \\ 357 & 15 & <1 & 6944 & <1 & <0.5 \\ 398 & 15 & <1 & 6510 & <1 & <0.5 \\ 364 & 21 & <1 & 6510 & <1 & <0.5 \\ 366 & 21 & <1 & 6944 & <1 & <0.5 \\ 396 & 21 & <1 & 6510 & <1 & <0.5 \\ 377 & 28 & <1 & 6062 & <1 & <0.5 \\ 382 & 28 & <1 & 6495 & <1 & <0.5 \\ 383 & 28 & <1 & 5629 & <1 & <0.5 \\ 355 & 35 & <1 & 9093 & <1 & <0.5 \\ 374 & 35 & <1 & 7794 & <1 & <0.5 \\ 391 & 35 & <1 & 8227 & <1 & <0.5\end{array}$


WSRC-STI-2006-00189, Rev. 0

Table A38. Data from the TCE re-spike experiment for treatment 4Fe.

$\begin{array}{cccccc}\text { Sample ID } & \text { Incubation } & \text { cDCE } & \text { TCE } & \text { VC } & \text { acetylene } \\ 487 & 0 & <1 & 8463 & <1 & <0.5 \\ 491 & 0 & <1 & 8723 & <1 & <0.5 \\ 498 & 0 & <1 & 8767 & <1 & <0.5 \\ 466 & 7 & <1 & 6076 & <1 & <0.5 \\ 468 & 7 & <1 & 6553 & <1 & <0.5 \\ 494 & 7 & <1 & 5946 & <1 & <0.5 \\ 471 & 15 & <1 & 5642 & <1 & <0.5 \\ 458 & 21 & <1 & 6076 & <1 & <0.5 \\ 464 & 28 & <1 & 5629 & <1 & <0.5 \\ 478 & 35 & <1 & 7794 & <1 & <0.5 \\ 490 & 35 & <1 & 7794 & <1 & <0.5\end{array}$


Table A38. Data from the TCE re-spike experiment for treatment $6 \mathrm{Fe}$.

$\begin{array}{rrlrll}\text { Sample ID } & \text { Incubation } & \text { cDCE } & \text { TCE } & \text { VC } & \text { acetylene } \\ 600 & 0 & <1 & 9591 & <1 & <0.5 \\ 601 & 0 & <1 & 8897 & <1 & <0.5 \\ 602 & 0 & <1 & 9678 & <1 & <0.5 \\ 618 & 7 & <1 & 8637 & <1 & <0.5 \\ 619 & 7 & <1 & 8854 & <1 & <0.5 \\ 620 & 7 & <1 & 8376 & <1 & <0.5 \\ 613 & 15 & <1 & 8246 & <1 & <0.5 \\ 614 & 15 & <1 & 9114 & <1 & <0.5 \\ 615 & 15 & <1 & 8246 & <1 & <0.5 \\ 616 & 21 & <1 & 8680 & <1 & <0.5 \\ 617 & 21 & <1 & 9114 & <1 & <0.5 \\ 622 & 21 & <1 & 8246 & <1 & <0.5 \\ 611 & 28 & <1 & 8227 & <1 & <0.5 \\ 612 & 28 & <1 & 8227 & <1 & <0.5 \\ 621 & 28 & <1 & 8227 & <1 & <0.5 \\ 603 & 35 & <1 & 10392 & <1 & <0.5 \\ 607 & 35 & <1 & 9093 & <1 & <0.5 \\ 608 & 35 & <1 & 9526 & <1 & <0.5\end{array}$

${ }^{\mathrm{i}}$ Zero valent zinc, 20 mesh, approximately 5 grams.

ii Zero valent magnesium, ribbon form, $\sim 3.5$ " strips, $\sim 0.15$ grams. 